Article

\title{
Glycodendrimers and Modified ELISAs: Tools to Elucidate Multivalent Interactions of Galectins 1 and 3
}

\author{
Mark Wolfenden ${ }^{1}$, Jonathan Cousin ${ }^{1}$, Pratima Nangia-Makker ${ }^{2}$, Avraham Raz ${ }^{2}$ and \\ Mary Cloninger ${ }^{1, *}$
}

1 Department of Chemistry and Biochemistry, Montana State University, Bozeman, MT 59717, USA; E-Mails: mlwolfenden@gmail.com (M.W.); jon.cousin@chemistry.montana.edu (J.C.)

2 The Departments of Oncology and Pathology, School of Medicine, Wayne State University, Detroit, MI 48201, USA; E-Mails: makkerp@karmanos.org (P.N.-M.); raza@karmanos.org (A.R.)

* Author to whom correspondence should be addressed; E-Mail:

mcloninger@chemistry.montana.edu; Tel.: +1-406-994-3051; Fax: +1-406-994-5407.

Academic Editor: Els Van Damme

Received: 5 March 2015 / Accepted: 1 April 2015 / Published: 20 April 2015

\begin{abstract}
Multivalent protein-carbohydrate interactions that are mediated by sugar-binding proteins, i.e., lectins, have been implicated in a myriad of intercellular recognition processes associated with tumor progression such as galectin-mediated cancer cellular migration/metastatic processes. Here, using a modified ELISA, we show that glycodendrimers bearing mixtures of galactosides, lactosides, and $\mathrm{N}$-acetylgalactosaminosides, galectin-3 ligands, multivalently affect galectin-3 functions. We further demonstrate that lactose functionalized glycodendrimers multivalently bind a different member of the galectin family, i.e., galectin-1. In a modified ELISA, galectin-3 recruitment by glycodendrimers was shown to directly depend on the ratio of low to high affinity ligands on the dendrimers, with lactose-functionalized dendrimers having the highest activity and also binding well to galectin-1. The results depicted here indicate that synthetic multivalent systems and upfront assay formats will improve the understanding of the multivalent function of galectins during multivalent protein carbohydrate recognition/interaction.
\end{abstract}

Keywords: ELISA; galectin-1; galectin-3; glycodendrimer; dendrimer; multivalent 


\section{Introduction}

Multivalent protein-carbohydrate interactions generally rely on multiple points of recognition/binding to enhance the individual binding interaction between one carbohydrate and its receptor, which are typically weak interactions [1]. A variety of synthetic multivalent scaffolds including linear polymers [2-4], star [5-7] and hyperbranched [8-10] polymers, gold nanoparticles [11-13], dendrimers [14], proteins [15], beads [16] and surfaces [17-20] have been functionalized with carbohydrates and then applied to the study and the mediation of multivalent protein-carbohydrate interactions [21]. These carbohydrate functionalized scaffolds have been used to study biological processes such as oncologic cellular aggregation [22] viral cell attachment [15,23], bacterial recognition [24], and signal transduction [25]. Applications for these glycosystems will no doubt become more widespread as the understanding of the roles of multivalent protein carbohydrate interactions in complex biological systems is improved [26].

One of the challenges of studying protein-carbohydrate interactions is the development of appropriate assays for assessment of heterogeneous binding interactions. Surface plasmon resonance (SPR) is very useful for studying binding interactions of lectins with surface-adhered glycans under flow [27,28]. Measurements are based on mass-change as lectins are bound and eluted from the glycan-adhered surface. Back scattering interferometry is a sensitive technique for studying lectin/glycan binding interactions both in solution and with surface-immobilized glycans, and detects the act of complexation without regard to size of the species [29]. Fluorescence binding assays, such as fluorescence resonance energy transfer (FRET) [30,31] or fluorescence lifetime (FL) [32,33], can be used to study thermodynamic binding interactions between disparately labelled lectin and glycan. Fluorescent binding assays can be expanded to a microarray format to analyze the influence of glycan valency, structure, and presentation on lectin binding [30,34]. Dynamic light scattering (DLS) is useful for studying the size of glycan/protein nanoparticles formed in solution [35-38]. This technique requires large amounts of sample and works best for relatively monodisperse nanoparticles. Fluorescence microscopy (FM), through fluorescent labelling of the protein or the glycoconjugate, can also be used to measure nanoparticle size [35]. Fluorescent labelling of cell-surface glycans can be used to investigate lectin-induced redistribution of glycans [39]. Isothermal titration calorimetry (ITC) is commonly used to measure binding constants in solutions [40,41]. ITC, however, requires large amounts of sample and is limited by the formation of insoluble protein/carbohydrate aggregates. A hemagglutination assay (HA) provides a model to study cellular adhesion mediated by lectin interactions with oligosaccharides expressed on the surface of red blood cells in a microtiter plate format, and can be used to detect the presence of a lectin or measure the minimum concentration of lectin to induce agglutination [42]. Precipitation assays are useful for studying the stoichiometry of lectin/glycan aggregates that precipitate out of solution but require large amounts of each species [2]. Enzyme linked immunosorbent assays (ELISAs) are relatively simple, high throughput platforms to detect the occurrence of binding interactions between lectins and surface-adhered glycans [43].

Clearly, due to the complexity of multivalent protein-carbohydrate interactions, a wide spectrum of assays has been developed. Some of the assays mimic a cell surface (SPR, BSI, ELISA), while others are intended to mimic non-surface bound multivalent assemblies of proteins with oligosaccharides (ITC, FL, DLS). Assays that incorporate cells (FM, HA) and assays that take advantage of phase 
changes upon binding (precipitation assay) have also been applied. All of these assays are valuable for elucidating the roles that multivalent protein-carbohydrate interactions have in biology and for determining the selectivity and specificity of interactions.

Here, we develop a straightforward assay for the evaluation of lectin(s) binding to/by members of a family of synthetic multivalent carbohydrates without the need to use specialized equipment. Systematic variations in the carbohydrate ligands and the size of structures should be easy to accommodate, enabling binding studies even for lectins that are not robust enough to be tethered to a surface or to be exposed to multiple washing/rejuvenation steps between trials. Taking these parameters into consideration, both SPR and ELISA would be good methods. Because we want to use a system in the absence of flow [44,45], we investigated the use of ELISAs for the systematic study of protein-carbohydrate interactions. Nuances associated with SPR, such as rebinding and model fitting, may provide a complementary but different analysis than the ELISA's reported here.

The use of ELISAs to study protein-carbohydrate interactions has already been reported for many systems, making this assay a good choice for further development [43,46-52]. Generally, a solid surface is functionalized by a layer of carbohydrates [53]. The lectin of interest is bound to this surface, and binding is detected using an antibody and a detection system such as horseradish peroxidase [53,54]. After lectin binding to the carbohydrate functionalized surfaces has been established, the synthetic multivalent systems are introduced to the lectin [55]. Following washing, the synthetic multivalent system is identified as a lectin binder. However, if binding is only partially or is not inhibited, then the synthetic multivalent system is determined to be only weakly bound or not bound by the lectin. Representative ELISA binding and inhibition experiments are presented in Figure 1a,b.

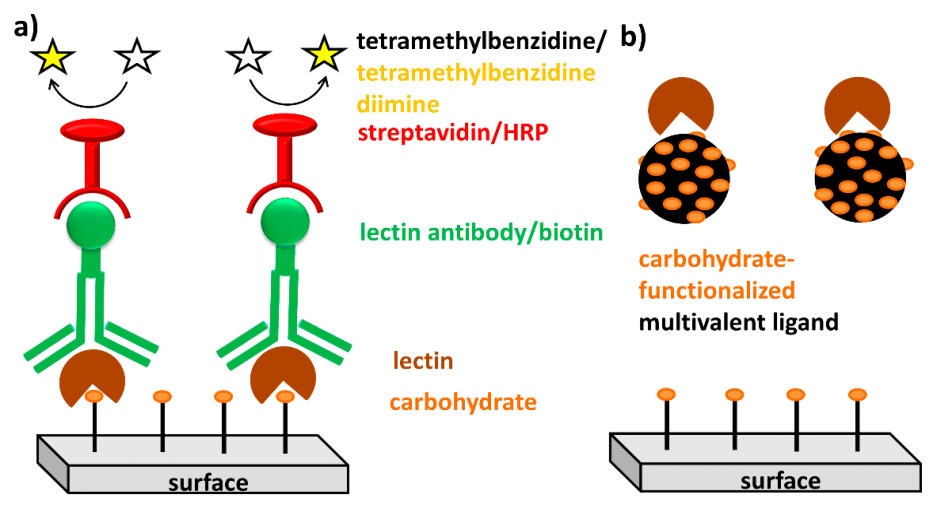

Figure 1. (a) Traditional ELISA with saccharide functionalized surface. Lectin binding is indicated by enzymatic oxidation of TMB, which produces a measurable color change; (b) Inhibition of lectin binding by a synthetic multivalent glycoconjugate is indicated by the absence of TMB oxidation.

For many lectins, the existing ELISA protocols work very well. For galectins, however, the ELISA and inhibition ELISA protocols could not be applied to the study of multivalent binding. We found that as soon as the smallest possible amount of glycodendrimer was added to an inhibition ELISA with galectin-3, a multivalent complex was formed that actually enhanced binding of the tested galectin to the surface (Figure 2). 


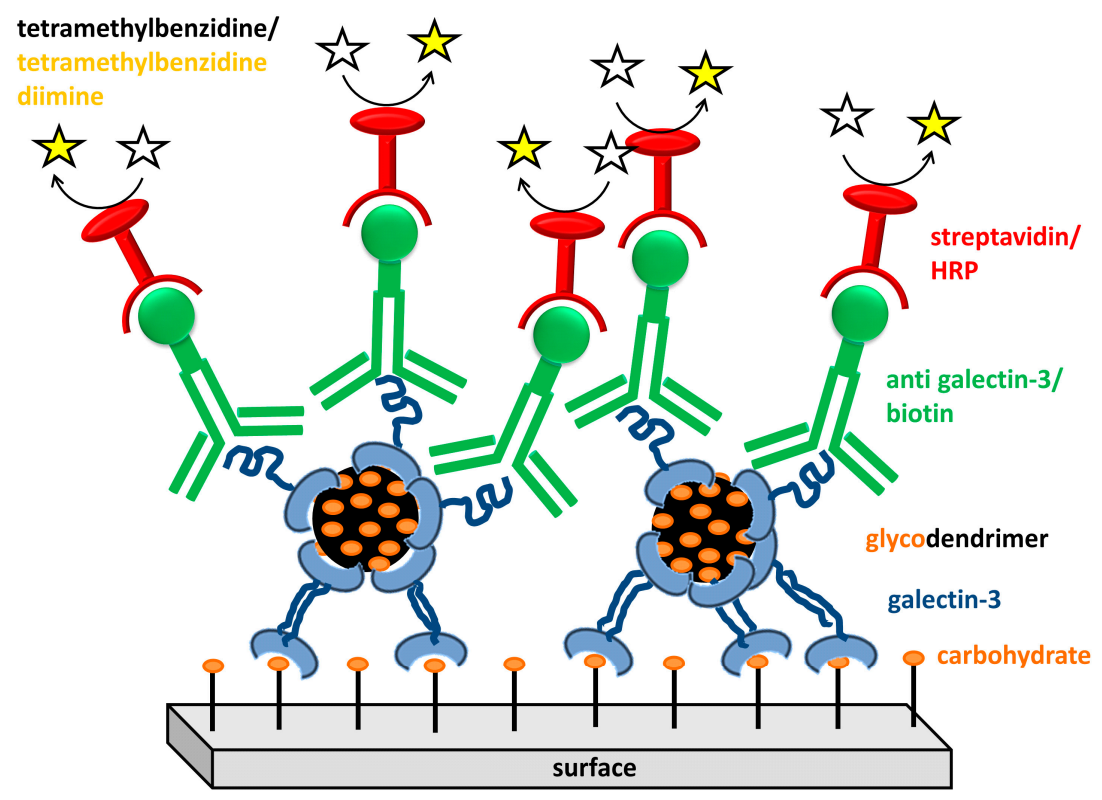

Figure 2. Multivalent complex formed with galectin-3 upon the addition of glycodendrimer. Using a traditional ELISA format with a carbohydrate-functionalized surface, glycodendrimers were observed to recruit galectin-3 rather than inhibit surface binding, which resulted in high absorbance measurements.

Using surface-immobilized synthetic glycodendrimers, Andre et al. investigated the influence of glyconjugate valency on galectin-1 and galectin-3 binding affinity [56]. Homodimeric galectin-1 exhibited increased binding affinity with increased ligand valency, while monomeric galectin-3 afforded only modest affinity enhancements with increasing valency. Based on this important precedence, our goal was to develop an ELISA protocol that can be used to rapidly and effectively determine the relative binding affinity of galectins (and other lectins) for a range of synthetic multivalent frameworks on a surface. We adsorbed to the surface a series of glycodendrimers of different generations and bearing carbohydrates with a range of binding affinities for the galectins. The assay design, results from the assay, surface characterization using X-ray photoelectron spectroscopy, and the synthesis of the glycodendrimers that were required to systematically test the assay are reported here.

\section{Results and Discussion}

Galectins-1 and -3 are members of the galectin family of galactoside-binding lectins [57-59]. Galectin-3 has a carbohydrate recognition domain and an N-terminal domain that is believed to enable aggregated states of the protein to occur [60]. Galectin-3 has been reported to be involved in mechanisms that cluster cell surface glycoproteins [61,62], cross-link receptors [63,64], and form lattices and larger aggregates [65], and these processes are involved in cellular function [66]. Galectin-1 is a prototype galectin that is found as a noncovalent dimer with monomeric subunits anchored such that the carbohydrate binding domains are located on opposing faces [57]. Similarly, galectin-1 has been reported to be involved in cell surface interactions that mediate cellular function [67-71]. Considering the complicated multivalent structures and the many multivalent functions of galectin-1 
and galectin-3, it is not surprising that traditional ELISAs and inhibition ELISAs are insufficient for studying their multivalent binding to synthetic multivalent frameworks.

\subsection{Glycodendrimers}

For the modified ELISAs, carbohydrate functionalized dendrimers 4-9, which are shown in Scheme 1, were adsorbed to polystyrene surfaces. To obtain the requisite dendrimers, sequential addition of compounds 1, 2, and $\mathbf{3}$ was performed (Scheme 1).
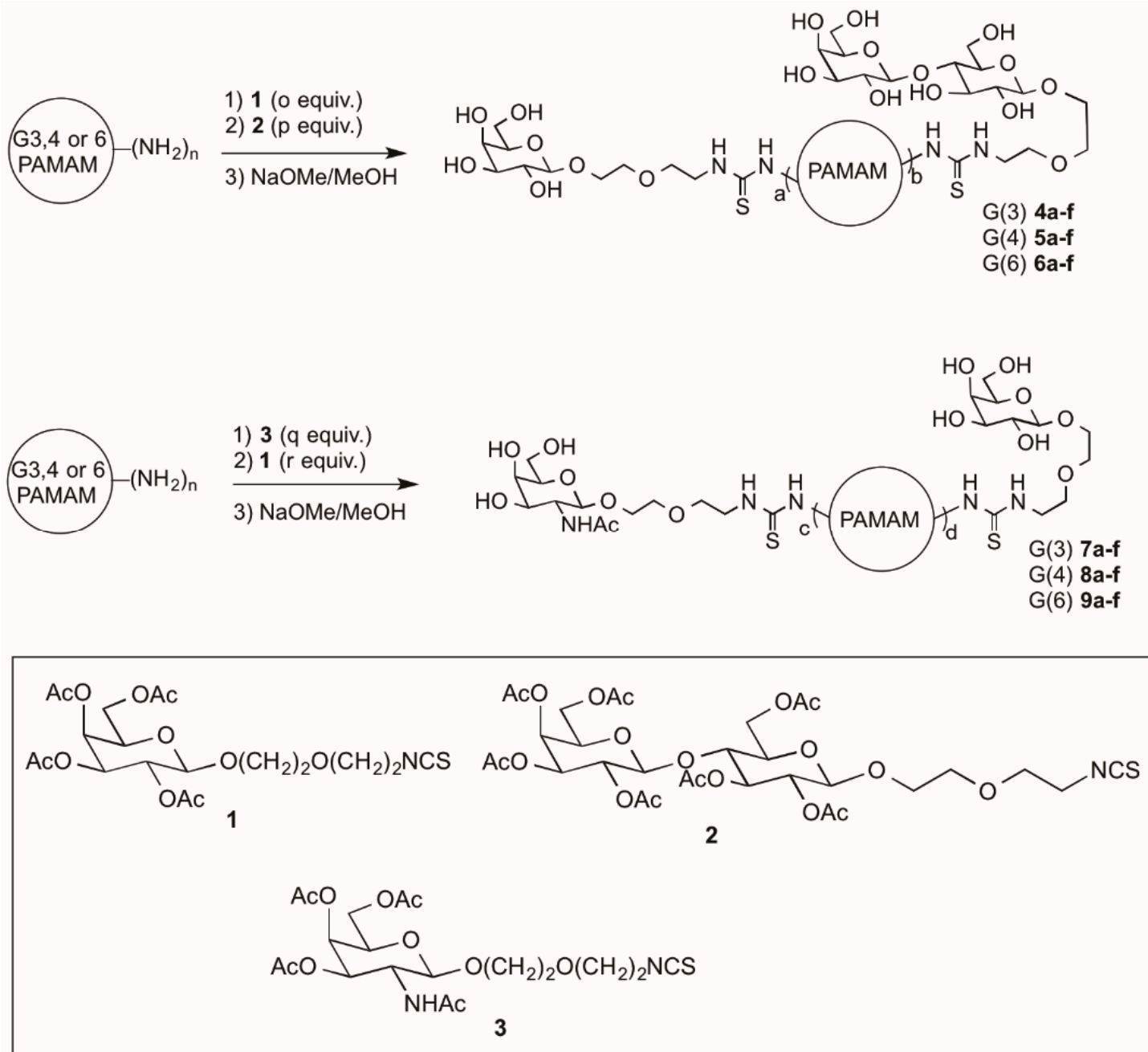

Scheme 1. Synthesis of carbohydrate functionalized PAMAM dendrimers. (Values for a-d are shown in Tables 1 and 2; numbers for o-r are given in the Experimental Section).

The synthesis of 2 has been previously reported [35], and the experimental methods for the syntheses of $\mathbf{1}$ and $\mathbf{3}$ are described in the Experimental Section. The degree of functionalization of the dendrimers with carbohydrates was determined by MALDI-TOF MS. The average amounts of sugars that were incorporated are shown in Tables 1 and 2.

The number of sugars attached to the dendrimer was determined using the change in the weight averaged molecular weight, $\mathrm{M}_{\mathrm{w}}$, after addition of the carbohydrates and the change in $\mathrm{M}_{\mathrm{w}}$ after deacetylation. 
Table 1. Results for Compounds $4 \mathbf{a}-\mathbf{f}, \mathbf{5 a}-\mathbf{f}$ and $\mathbf{6 a}-\mathbf{f}$ with galectin-3.

\begin{tabular}{ccccccc}
\hline $\begin{array}{c}\text { Compound } \\
\text { Number }\end{array}$ & $\begin{array}{c}\text { PAMAM } \\
\text { Generation }\end{array}$ & $\begin{array}{c}\text { Number of } \\
\text { Galactose Sugars (a) }\end{array}$ & $\begin{array}{c}\text { Number of } \\
\text { Lactose Sugars (b) }\end{array}$ & $\begin{array}{c}\text { Total Number } \\
\text { of Sugars }\end{array}$ & $\begin{array}{c}\text { IC50 (mM) } \\
\text { Lactose }\end{array}$ & $\begin{array}{c}\text { Maximum } \\
\text { Absorbance Value }\end{array}$ \\
\hline 4a & 3 & 0 & 24 & 24 & 0.31 & 1.03 \\
$\mathbf{4 b}$ & 3 & 7 & 20 & 27 & 0.21 & 1.56 \\
$\mathbf{4 c}$ & 3 & 14 & 12 & 26 & 0.12 & 1.33 \\
$\mathbf{4 d}$ & 3 & 19 & 8 & 27 & 0.09 & 0.93 \\
$\mathbf{4 e}$ & 3 & 24 & 3 & 27 & 0.12 & 0.66 \\
$\mathbf{4 f}$ & 3 & 26 & 0 & 26 & 0.05 & 0.39 \\
$\mathbf{5 a}$ & 4 & 0 & 57 & 57 & 0.15 & 1.28 \\
$\mathbf{5 b}$ & 4 & 17 & 36 & 53 & 0.19 & 1.32 \\
$\mathbf{5 c}$ & 4 & 28 & 25 & 53 & 0.20 & 1.02 \\
$\mathbf{5 d}$ & 4 & 34 & 14 & 48 & 0.19 & 0.97 \\
$\mathbf{5 e}$ & 4 & 44 & 7 & 51 & 0.28 & 0.84 \\
$\mathbf{5 f}$ & 4 & 57 & 0 & 57 & 0.15 & 0.60 \\
$\mathbf{6 a}$ & 6 & 0 & 130 & 130 & 0.09 & 0.84 \\
$\mathbf{6 b}$ & 6 & 37 & 102 & 139 & 0.20 & 0.77 \\
$\mathbf{6 c}$ & 6 & 59 & 83 & 142 & 0.14 & 0.75 \\
$\mathbf{6 d}$ & 6 & 83 & 55 & 138 & 0.15 & 0.77 \\
$\mathbf{6 e}$ & 6 & 105 & 38 & 142 & 0.12 & 0.73 \\
$\mathbf{6 f}$ & 6 & 145 & 0 & 145 & 0.11 & 0.38 \\
\hline
\end{tabular}

${ }^{a}$ Numbers a and b correspond to the sugar loading shown in Scheme 1.

Table 2. Results for Compounds 7a-f, 8a-f and 9a-f with galectin-3.

\begin{tabular}{|c|c|c|c|c|c|c|}
\hline $\begin{array}{l}\text { Compound } \\
\text { Number }\end{array}$ & $\begin{array}{c}\text { PAMAM } \\
\text { Generation }\end{array}$ & $\begin{array}{c}\text { Number of Galactose } \\
\text { Sugars (c) }\end{array}$ & $\begin{array}{c}\text { Number of GalNAc } \\
\text { Sugars (d) } \\
\end{array}$ & $\begin{array}{c}\text { Total Number } \\
\text { of Sugars }\end{array}$ & $\begin{array}{c}\mathrm{IC}_{50}(\mathrm{mM}) \\
\text { Lactose }\end{array}$ & $\begin{array}{c}\text { Maximum } \\
\text { Absorbance Value }\end{array}$ \\
\hline $7 a$ & 3 & 21 & 5 & 26 & 0.32 & 1.11 \\
\hline $7 b$ & 3 & 15 & 10 & 25 & 0.34 & 1.14 \\
\hline $7 \mathrm{c}$ & 3 & 11 & 15 & 26 & 0.32 & 1.14 \\
\hline $7 d$ & 3 & 8 & 19 & 27 & 0.38 & 1.36 \\
\hline $7 e$ & 3 & 2 & 24 & 26 & 0.32 & 0.98 \\
\hline $7 f$ & 3 & 0 & 28 & 28 & 0.29 & 0.92 \\
\hline $8 a$ & 4 & 46 & 10 & 56 & 0.19 & 0.82 \\
\hline $8 b$ & 4 & 33 & 22 & 55 & 0.15 & 0.89 \\
\hline $8 c$ & 4 & 25 & 31 & 56 & 0.16 & 0.82 \\
\hline $8 d$ & 4 & 12 & 40 & 52 & 0.06 & 0.71 \\
\hline $8 e$ & 4 & 7 & 49 & 56 & 0.06 & 0.82 \\
\hline $8 f$ & 4 & 0 & 54 & 54 & 0.07 & 0.53 \\
\hline 9a & 6 & 109 & 32 & 141 & 0.35 & 0.81 \\
\hline $9 b$ & 6 & 85 & 54 & 139 & 0.27 & 1.40 \\
\hline $9 \mathrm{c}$ & 6 & 56 & 85 & 141 & 0.40 & 1.25 \\
\hline 9d & 6 & 43 & 105 & 148 & 0.29 & 1.17 \\
\hline $9 e$ & 6 & 9 & 134 & 143 & 0.29 & 1.07 \\
\hline 9f & 6 & 0 & 154 & 154 & 0.36 & 0.94 \\
\hline
\end{tabular}

${ }^{a}$ Numbers c and d correspond to the sugar loading shown in Scheme 1. 


\subsection{Modified ELISA Using Surface Adsorbed Glycodendrimers and Galectin-3}

The ELISA to study the dendrimer:galectin-3 binding interaction is based upon the dendrimer adsorbing to the 96 well plate and subsequently inhibiting the dendrimer:galectin-3 interaction with varying concentrations of lactose as shown in Figure 3. This method is similar to that reported by Roy, Gabius, and co-workers [56] and allowed for comparison of the relative binding associations of compounds 4a-f, 5a-f, 6a-f, 7a-f, 8a-f and 9a-f with galectin-3. Other ELISA methods were investigated such as adsorbing laminin and asialofetuin to the plate and then using the sugar functionalized dendrimers to inhibit the glycoprotein: galectin-3 surface interaction. However, these protocols inevitably resulted in very high galectin-3 binding to the surface. This result is suggestive of a cooperative glycodendrimer/galectin-3 system that caused galectin-3 to bind strongly to the plate even at very high dendrimer concentrations (Figure 2).

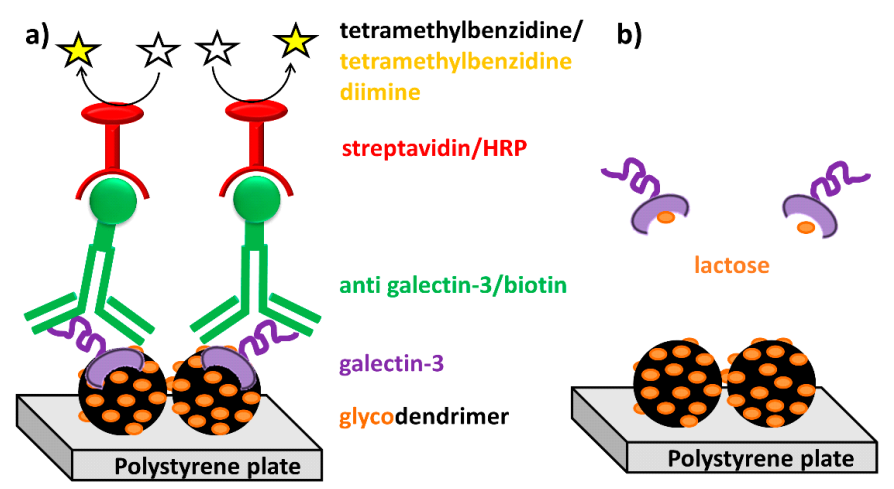

Figure 3. Modified ELISA to study galectin-3 interactions. (a) Glycodendrimers were adsorbed to the surface of a plate, and galectin-3 was added to measure binding affinity;

(b) Monomeric lactose was added to inhibit galectin-3 binding to the glycodendronized surface.

To measure the efficacy of the monomer carbohydrates for binding to galectin-3, an ELISA was performed with 4a, 5a and $\mathbf{6 a}$ adsorbed to the 96 well plates, and galactose, GalNAc, lactose, and mannose were used separately as inhibitors of galectin-3 binding by the adsorbed glycodendrimers. Binding curves are shown in Figure S1 of the Supplementary Material. Previous studies have indicated different binding constants for various carbohydrates, both natural and chemically modified, with galectin-3 [72,73]. According to the ELISA inhibition assay using 4a with various inhibitors and setting the relative $\mathrm{IC}_{50}$ value for lactose to 1 , GalNAc and galactose had relative $\mathrm{IC}_{50}$ values of 111 and 90, respectively. Using 5a with various inhibitors and setting the relative $\mathrm{IC}_{50}$ value for lactose to 1, GalNAc had a relative inhibitory potency value of 41 and galactose of 46 . Using $\mathbf{6 a}$ with various inhibitors and setting the relative $\mathrm{IC}_{50}$ value for lactose to 1 , GalNAc had a relative inhibitory potency value of 40 and galactose of 50. This is in agreement with a report by Brewer et al. of a 66-fold increase in affinity for lactose over galactose using a hemagglutination inhibition assay [72]. Interestingly, there appeared to be little or no difference between the relative $\mathrm{IC}_{50}$ values for galactose and GalNAc. This suggests the $N$-acetyl group on GalNAc does not have a significantly different binding interaction than the $2^{\prime} \mathrm{OH}$ group on galactose upon binding to galectin-3. This is not entirely surprising considering the $2^{\prime} \mathrm{OH}$ position on lactose in X-ray crystallography studies appears to have 
no major interaction with galectin-3 [58]. However, hydrophobic substituents at the 2'OH position have afforded significantly increased binding constants relative to galactose for galectin-3 binding [74].

ELISA binding curves and surface characterization information for galactose/lactose functionalized dendrimers are shown in Figure 4. The results of compounds $\mathbf{4 a - f}$ binding with galectin-3 are shown in Figure $4 \mathrm{a}$, and the $\mathrm{IC}_{50}$ lactose inhibition values are reported in Table 1 . The IC50 values ranged from $0.05 \mathrm{mM}$ for $\mathbf{4 f}$ to $0.31 \mathrm{mM}$ for $\mathbf{4 a}$. Shown in Figure $4 \mathrm{~b}$ are the ELISA binding curves for $\mathbf{5 a}-\mathbf{f}$, and the reported lactose inhibition values are reported in Table 1. These $\mathrm{IC}_{50}$ values ranged from $0.15 \mathrm{mM}$ for $\mathbf{5 a}$ and $\mathbf{5 f}$ to $0.28 \mathrm{mM}$ for $\mathbf{5 e}$. Shown in Figure $4 \mathrm{c}$ are the ELISA binding curves for $\mathbf{6 a}-\mathbf{f}$, and the reported lactose $\mathrm{IC}_{50}$ values are provided in Table 1 . These $\mathrm{IC}_{50}$ values ranged from $0.09 \mathrm{mM}$ for $\mathbf{6 a}$ to $0.20 \mathrm{mM}$ for $\mathbf{6 b}$. Shown in Figure $4 \mathrm{~d}$ is a comparison of surface adsorptions for dendrimers with different endgroups. Additional details about Figure 4d are provided in Section 2.4 below.

a)

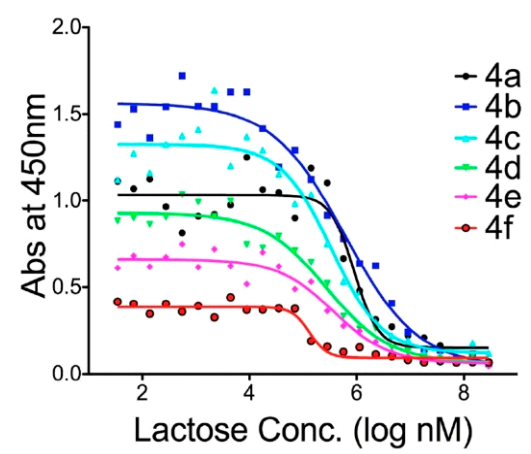

c)

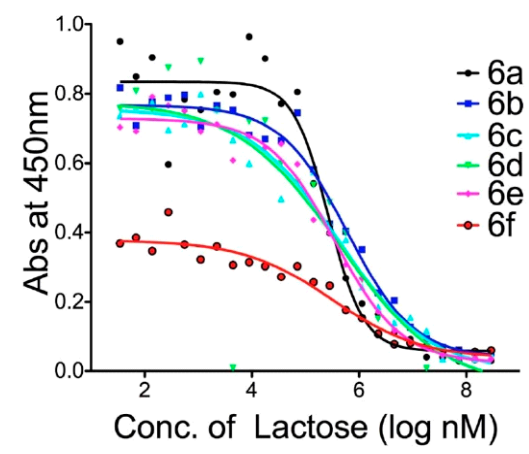

b)

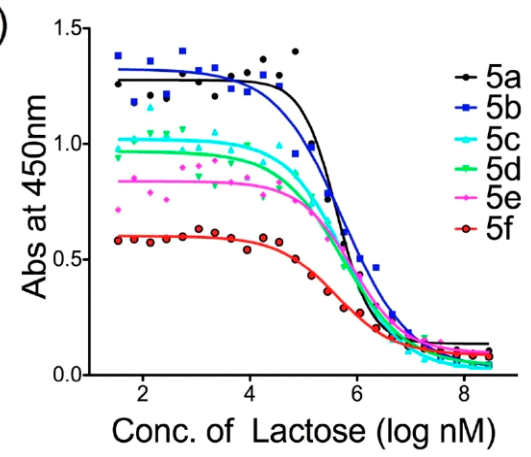

d)

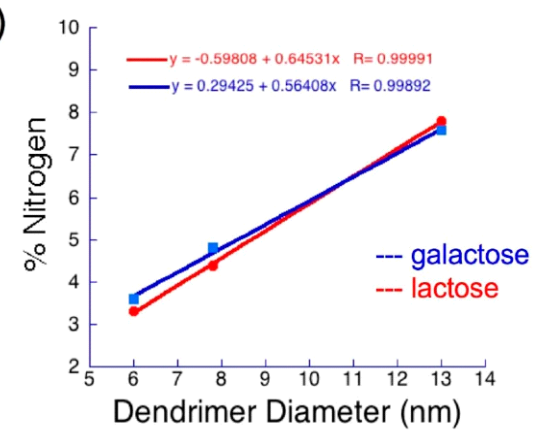

Figure 4. ELISA binding curves with (a) 4a-f; (b) 5a-f; (c) 6a-f and (d) XPS results of dendrimer diameter $v s$. nitrogen $\%$ for compounds $4 \mathbf{a}, 5 \mathbf{a}, 6 \mathbf{a}$ and $4 \mathbf{f}, \mathbf{5 f}, \mathbf{6}$.

ELISA binding curves and surface characterization information for galactose/GalNAc functionalized dendrimers are shown in Figure 5. The ELISA binding curves of compounds $\mathbf{7 a - f}$ are depicted in Figure 5a (lactose inhibiting concentrations are shown in Table 2). All of the measured lactose inhibiting concentrations were very similar, ranging from $0.29 \mathrm{mM}$ (7f) to $0.38 \mathrm{mM}$ (7d). For compounds 8a-f the ELISA binding curves are shown in Figure 5b, and the lactose inhibiting concentrations are reported in Table 2. The $\mathrm{IC}_{50}$ values ranged from $0.06 \mathrm{mM}$ for $\mathbf{8 d}$ and $8 \mathbf{e}$ to 0.19 $\mathrm{mM}$ for 8a. Shown in Figure 5c are the ELISA binding curves for compounds 9a-f and the reported lactose inhibiting concentrations are reported in Table 2. The $\mathrm{IC}_{50}$ values ranged from $0.27 \mathrm{mM}$ for $\mathbf{9 b}$ to $0.40 \mathrm{mM}$ for $9 \mathrm{c}$. Shown in Figure $5 \mathrm{~d}$ is a comparison of surface adsorptions for dendrimers with different endgroups. Additional details about Figure 5d are provided in Section 2.4 below. 
a)

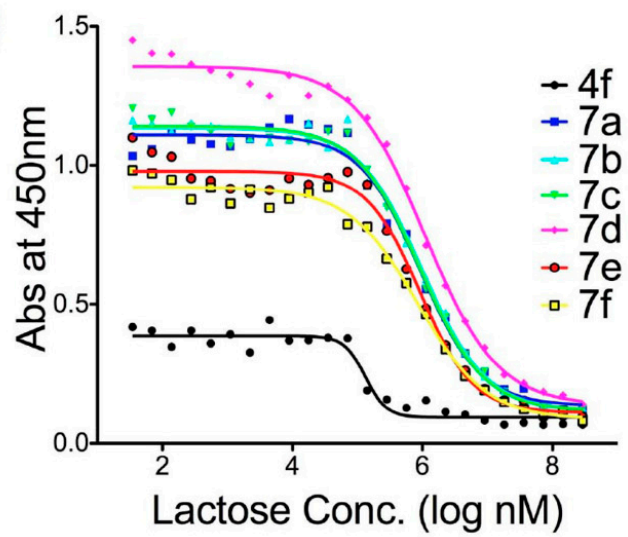

c)

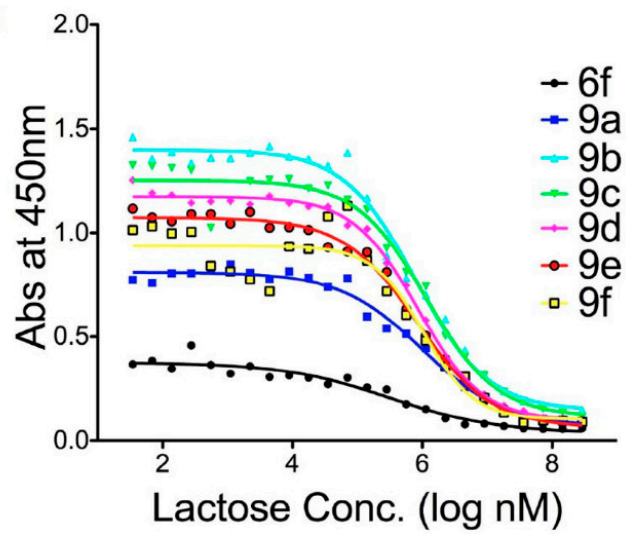

b)

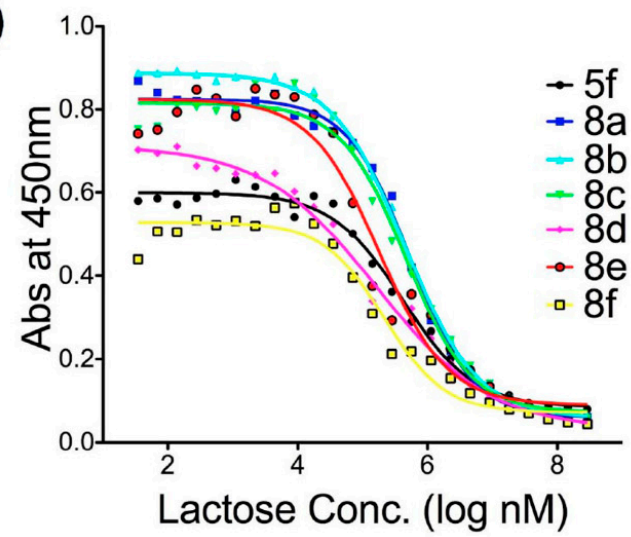

d)

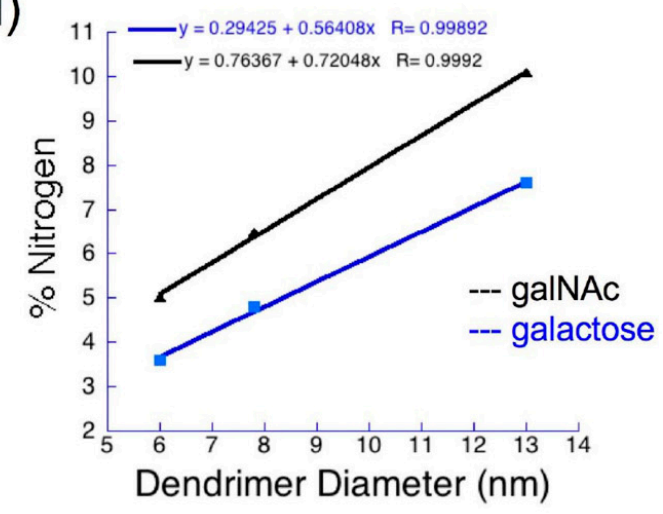

Figure 5. ELISA binding curves with (a) 4f, 7a-f; (b) 5f, 8a-f; (c) 6f, 9a-f and (d) XPS results of dendrimer diameter $v s$. nitrogen \% for compounds $4 \mathbf{f}, \mathbf{5 f}, \mathbf{6 f}$ and $7 \mathbf{f}, \mathbf{8 f}, 9$ f.

These results suggest that the carbohydrates which were presented on the dendrimers 4-9 a-f did not have a great effect upon the binding affinity of the glycodendrimers toward galectin-3 as measured in a competitive ELISA based assay. In contrast, the amount of galectin-3 that was recruited by the surface bound dendrimer increased significantly with higher lactose loading. For example in Figure $2 b$, the maximum absorbance for $\mathbf{5 b}$ is 1.32 and for $\mathbf{5 f}$ is 0.60 , and other compounds in this series follow an increasing trend in higher maximum absorbance values with higher lactose loadings. This trend is also apparent in the third generation series of lactose: galactose functionalized dendrimers (Figure 2a), with the exception of $\mathbf{4 a}$. The maximum absorbance value for $\mathbf{4 b}$ was 1.56 and was 0.39 for $\mathbf{4 f}$, again with an increasing trend in maximum absorbance value with higher lactose loading. With sixth generation dendrimers, it appears that even with lower lactose loading, the galectin-3 recruitment does not change significantly. However, with fully galactose functionalized G(6), 6f, the galectin-3 maximum absorbance is 0.38 , which is much lower than the maximum absorbance values of the other G(6) lactose: galactose functionalized dendrimers (absorbance values for $\mathbf{6 a}-\mathbf{e}$ are $0.84,0.77,0.75$, 0.77 and 0.73 , respectively).

Previously, we showed that the activity of dendrimers toward concanavalin A, a model plant lectin that is commonly used to study multivalent protein-carbohydrate interactions, was linearly dependent on the ratio of low to high affinity ligands that were present on dendrimers [75]. In Figure 6, the linear correlation between the recruitment of galectin-3 to the dendronized surface and the ratio of lactose to galactose is clearly visible for third generation compounds $\mathbf{4 b}-\mathbf{f}$ and for fourth generation 
compounds 5b-f. For the sixth generation series of dendrimers $\mathbf{6 a}-\mathbf{f}$, the plot levels off upon functionalization of about $30 \%$ of the dendrimer endgroups with lactose. The difference in galectin-3 recruitment is negligible for addition of a further ninety lactosides (maximum absorbance values at 450 $\mathrm{nm}$ are very similar for $\mathbf{6 a - e}$ ), indicating that dendrimers can ultimately be functionalized with additional groups as needed without reducing the galectin-3/glycodendrimer binding interaction.

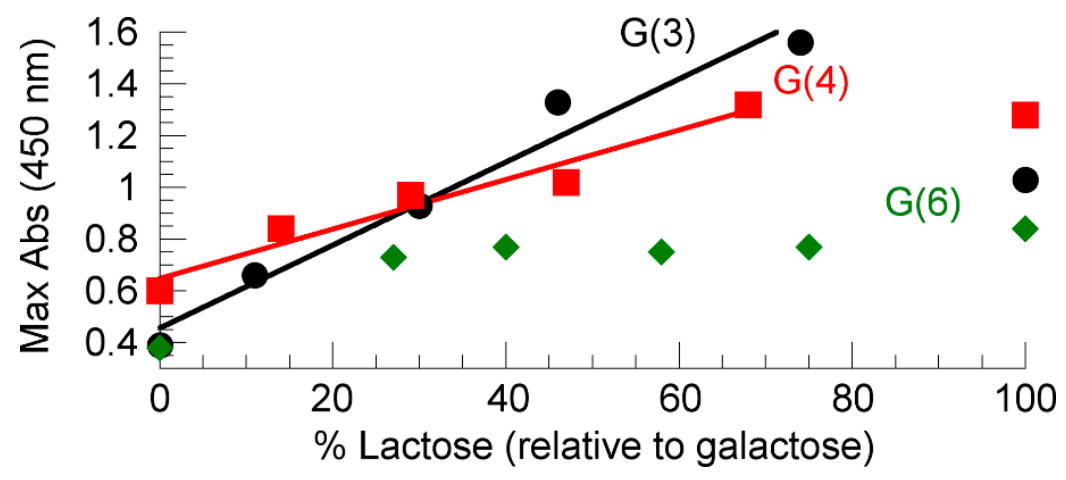

Figure 6. Percent lactose of the lactose/galactose functionalized dendrimers vs. maximum absorbance for binding of galectin-3 in a modified ELISA.

\subsection{ELISA Using Surface Adsorbed Glycodendrimers with Galectin-1}

After using the modified ELISA to study galectin-3 binding interactions with glycodendrimers, we validated the broader utility of this assay by studying the binding of galectin-1 to lactose functionalized dendrimers adsorbed to the polystyrene surface. The design of the ELISA is basically the same as was used for galectin-3, except galectin-1 was biotinylated and the anti-galectin antibody was eliminated (Figure 7).

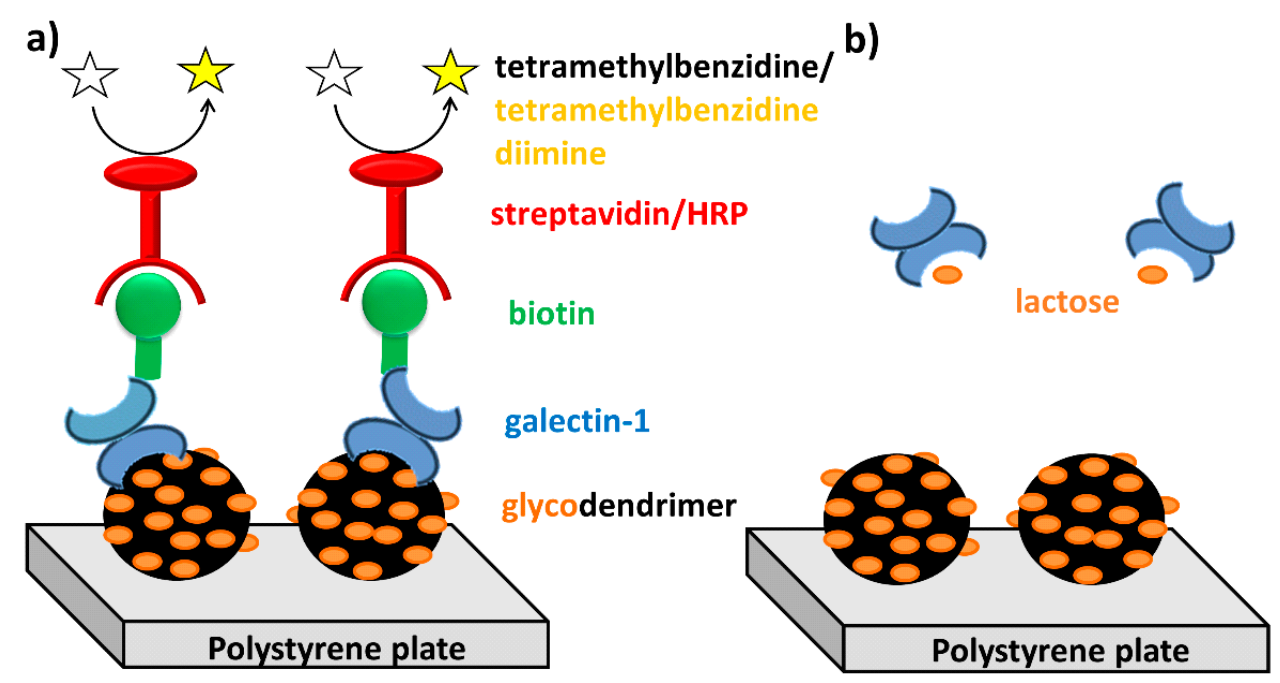

Figure 7. Modified ELISA to study galectin-1 binding interactions. (a) Glycodendrimers were adsorbed to the surface of a plate, and biotinylated galectin-1 was added to measure binding affinity; (b) Monomeric lactose was added to inhibit galectin-1 binding to the glycodendronized surface. 
Galectin-1 binding to 4a, 5a, and 6a was observed as shown in Figure 8. In addition to showing that galectin-1 does bind well to the glycodendrimers, relative differences among glycodendrimer architectures were evaluated by comparing the maximum absorbance values and the IC50 values for the three generations of glycodendrimers. Maximum absorbance values correspond to the relative amount of galectin-1 recruited by the glycodendrimers. The results indicate that larger glycodendrimers, which bear more ligands, recruit more galectin-1: the amount of galectin-1 recruited by $\mathbf{4}$ was less than half the amount recruited by 6 .

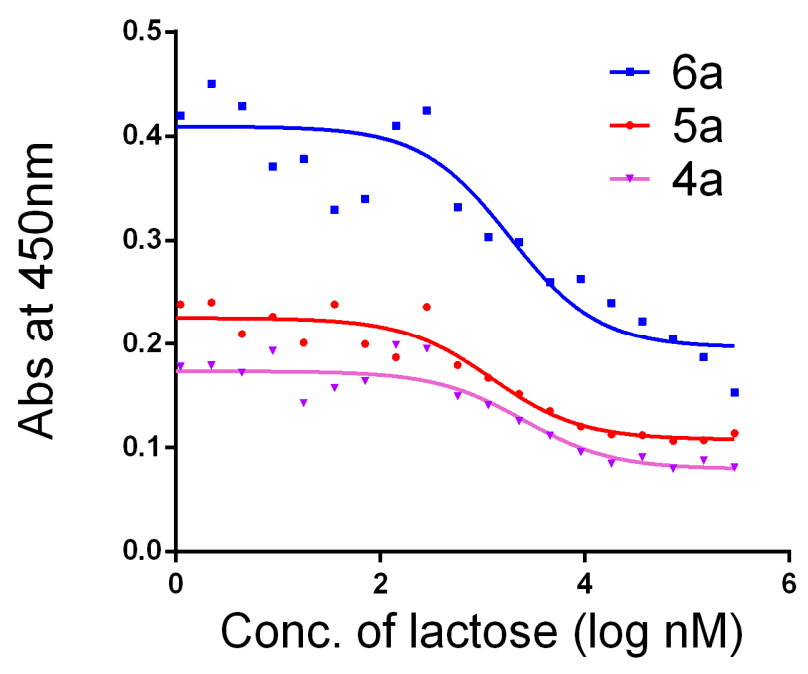

Figure 8. ELISA binding curve with $\mathbf{4 a}, \mathbf{5 a}$, and $\mathbf{6 a}$.

$\mathrm{IC}_{50}$ values calculated from the inhibition ELISA binding curves are shown in Table 3. The highest $\mathrm{IC}_{50}$ value with galectin-1 was for third generation lactose functionalized dendrimer $\mathbf{4 a}$. $\mathrm{IC}_{50}$ values for fourth and sixth generation glycodendrimers 5a and 6a were about $30 \%$ lower, and the range in $\mathrm{IC}_{50}$ values was narrow, indicating that a consistent binding interaction occurs for all generations of glycodendrimers.

Table 3. Results for Compounds 4a, 5a, and 6a with galectin-1.

\begin{tabular}{ccccc}
\hline Compound Number & PAMAM Generation & $\begin{array}{c}\text { Number of } \\
\text { Lactose Sugars }\end{array}$ & $\begin{array}{c}\text { IC50 (nM) } \\
\text { Lactose }\end{array}$ & $\begin{array}{c}\text { Maximum } \\
\text { Absorbance Values }\end{array}$ \\
\hline 4a & 3 & 20 & 2.52 & 0.17 \\
$\mathbf{5 a}$ & 4 & 45 & 1.85 & 0.23 \\
$\mathbf{6 a}$ & 6 & 100 & 1.74 & 0.41 \\
\hline
\end{tabular}

\subsection{Characterization of Surfaces after Adsorption of Glycodendrimers}

X-ray photoelectron spectroscopy (XPS) was used to analyze the amount of the glycodendrimer that adsorbs to the polystyrene plates that were used in the ELISAs. Figure $4 \mathrm{~d}$ shows the amount of nitrogen, which was used to analyze dendrimer coating, in comparison to the dendrimer diameters (as reported previously by this group [76]) for lactose and galactose functionalized dendrimers. The linear relationship between dendrimer radius and nitrogen content indicates that the same amount of dendrimer is adsorbed to the surface regardless of which carbohydrate (lactose or galactose) was 
present. As shown in Figures $4 \mathrm{~d}$ and $5 \mathrm{~d}$, the linear relationship between dendrimer radius and nitrogen content is consistent, with $R$ values of 0.9999 for $\mathbf{4 a}, 5 \mathbf{a}$ and $\mathbf{6 a}, 0.9989$ for $\mathbf{4 f}, \mathbf{5 f}$ and $\mathbf{6 f}$, and 0.9992 for $7 \mathbf{f}, 8 f$ and $9 f$. Compounds $4 \mathbf{a}-\mathbf{6 a}$ and $4 \mathbf{f}-\mathbf{6 f}$ have the same amount of nitrogen and gave the same amounts of nitrogen signal relative to the dendrimer diameter. Compounds $\mathbf{7 f - 9 f}$ have the 2-NHAc group, and this increases the nitrogen signal. Within the fourth generation dendrimer series, $\mathbf{5 f}$ and $\mathbf{5 a}$ would theoretically contain 303 nitrogens and $\mathbf{8 f}$ would contain 358 nitrogens (assuming perfect PAMAM dendrimers). These values correspond to an $18 \%$ increase in nitrogen signal for GalNAc over lactose or galactose functionalized dendrimers. However, in the XPS experiments, the increase in the nitrogen signal for $\mathbf{8 f}$ was significantly higher than $18 \%$. This was also observed with the $G(3)$ and $G(6)$ series. As shown in Figure 5d, the trend for the GalNAc functionalized dendrimers is also consistent with dendrimer diameter, but dendrimer adsorption is consistently higher for GalNAc functionalized dendrimers than it is for the galactose and lactose functionalized dendrimers. The amount of galactose functionalized dendrimers 7-9a and lactose functionalized dendrimers 4-6a adsorbed to the surface was shown by XPS to be equal and consistent, indicating formation of a monolayer. The GalNAc functionalized dendrimers 7-9f appeared to adsorb somewhat better, but monolayer formation, as shown by the linearity of the relationship between the radius of the dendrimer and the concentration of nitrogen, is still indicated. This increase in adsorption by GalNAc functionalized dendrimers is in agreement with the higher maximum absorbance values that were observed in the modified ELISAs for these compounds. The XPS experiments suggest that the higher galectin-3 recruitment that was observed for glycodendrimers that had higher GalNAc loadings when compared to dendrimers with more galactose residues was due to differences in adsorption rather than differences in protein binding affinity.

Computer simulations suggest that dendrimers lie flat on a surface and that increased interaction strength results in spreading out and flattening of the dendrimers [77]. These simulations were supported by subsequent studies with transmission electron microscopy, which showed that surface adsorbed dendrimers adopt a circular shape [78]. When glycosides are conjugated to the PAMAM backbone, the resulting glycodendrimers adopt a circular shape with a slight declivity in the center upon surface adsorption [76]. Ligands are likely located in a volume shell on the periphery of the donut-shaped, surface adsorbed glycodendrimers, and the lectins cluster around the exposed surface [79].

\subsection{Discussion}

Although the preferred aggregation state of galectin-3 at the cell surface remains obscure, the modified ELISA results displayed here show very similar binding avidity for all the dendrimers, which indicates that the interaction between galectin-3 and glycodendrimers is not monomeric. If the glyco-dendrimer/galectin-3 interaction were monomeric, then the results with glycodendrimers would resemble the results with the monomer inhibitors, and they do not. The trends of increasing galectin-3 recruitment with higher lactose loading suggest that another (not monomeric) process is playing a large role in how these surface bound dendrimers interact with galectin-3. The capacity of the dendrimer to bind galectin-3 was observed to increase when the dendrimers were functionalized with higher affinity carbohydrates compared to results with glycodendrimers bearing lower affinity carbohydrates. This process of multivalently recruiting varying amounts of galectin-3 by the glycodendrimers could be 
similar to a cell surface receptor cluster mechanism. The ELISA results indicate that lectin recruitment may have a powerful role in clustering specific receptors.

Two properties of the galectin-1 binding interaction with glycodendrimers are evident from the binding assays. First, galectin-1 recruitment was valency-dependent in a manner similar to galectin-3, with more galectin-1 recruitment occurring for higher generation dendrimers. Second, inhibition of the galectin-1/glycodendrimer interaction by monomeric lactose was similar regardless of the size/generation of the glycodendrimer. The similarity in the $\mathrm{IC}_{50}$ values observed for $\mathbf{4 a}, \mathbf{5 a}$, and $\mathbf{6 a}$ suggests that galectin-1 was bound to each generation with a similar affinity regardless of the fundamental architectural differences in size, valency, and ligand density among the dendrimer generations.

We recognize that the modified ELISA performed here might be somewhat artificial due to the washing steps and tower building inherent in an ELISA. However the similarity in $\mathrm{IC}_{50}$ values for galectin-3 and surface bound dendrimer with very different sugar epitopes, as well as the similarity in $\mathrm{IC}_{50}$ values for galectin-1 binding to different generations of lactose functionalized dendrimers, require an explanation that goes beyond monomeric interaction. This explanation could be similar to the "bind and slide" mechanism presented by Brewer and co-workers, which could explain the trend in maximum galectin recruitment [80]. An equilibrium in which galectin-3 binds preferentially to the higher affinity sugars on the heterogeneously functionalized glycodendrimers is also likely, and as evidenced by the higher recruitment of galectin-3 when there are higher affinity lactose sugars available. The modified ELISA results reported here indicate that a multivalent mechanism is at play [1], most likely involving an interplay of different effects such as lectin clustering [76,81,82], bivalent (or higher order) interactions $[34,83]$ and statistical concentration effects $[84,85]$.

\section{Experimental Section}

\subsection{General Methods}

General reagents were purchased from Acros Organics (Pittsburgh, PA, USA) and Aldrich Chemical Company (Milwaukee, WI, USA). PAMAM dendrimers were purchased from Dendritech (Midland, MI, USA). Methylene chloride was purified on basic alumina; other solvents were used as received. 32-63 $\mu$ "40 micron flash" silica gel for flash column chromatography purification was purchased from Scientific Adsorbents Incorporated (Atlanta, GA, USA).

\subsection{Matrix Assisted Laser Desorption Ionization Time of Flight MS (MALDI-TOF)}

MALDI mass spectra were acquired using a Biflex-III time-of-flight mass spectrometer (Bruker, Billerica, MA, USA). Spectra of all functionalized dendrimers were obtained using a trans-3indoleacrylic acid matrix with a matrix-analyte ratio of 3000:1 or 1000:1. Bovine serum albumin (molecular weight, MW, 66,431 g/mol), cytochrome C (MW 12,361 g/mol), and trypsinogen (MW $23,982 \mathrm{~g} / \mathrm{mol}$ ) were used as external standards. An aliquot corresponding to $12-15 \mathrm{pmol}$ of the analyte was deposited on the laser target. Positive ion mass spectra were acquired in linear mode and the ions were generated by using a nitrogen laser $(337 \mathrm{~nm})$ pulsed at $3 \mathrm{~Hz}$ with a pulse width of 3 nanoseconds. Ions were accelerated at 19-20,000 volts and amplified using a discrete dynode multiplier. Spectra (100 to 200) were summed into a LeCroy LSA1000 high-speed signal digitizer. All data processing 
was performed using the Bruker XMass/XTOF V 5.0.2 software (Bruker, Billerica, MA, USA). Molecular mass data and polydispersities (PDI) of the broad peaks were calculated by using the Polymer Module included in the software package. The peaks were analyzed using the continuous mode. MALDI-TOF MS spectra were obtained after each addition of isothiocyanate, and the change in $\mathrm{M}_{\mathrm{w}}$ upon the first addition was divided by the $\mathrm{M}_{\mathrm{w}}$ of the isothiocyanato carbohydrate (galNAc $476 \mathrm{~g} / \mathrm{mol}$, galactose $477 \mathrm{~g} / \mathrm{mol}$ ) to give a quantity that is denoted here as A (Equation (1)). The total number of carbohydrate residues added for the second addition (B in Equation (2)) was determined by subtracting $M_{w}$ for unfunctionalized PAMAM from the $M_{w}$ after each sequential additions of isothiocyanate and then dividing by the $\mathrm{M}_{\mathrm{w}}$ of that carbohydrate (galactose $-477 \mathrm{~g} / \mathrm{mol}$, galNAc $-476 \mathrm{~g} / \mathrm{mol}$, lactose $765 \mathrm{~g} / \mathrm{mol}$ ), and this sum was the total, shown as C (Equation (3)). The total number of carbohydrate residues was also determined by dividing the change in $\mathrm{M}_{\mathrm{w}}$ upon deacylation by 168 (the loss of four acetyl groups per galactose), 126 (the loss of three acetyl groups per galNAc) or 294 (the loss of seven acetyl groups per lactose) and this number is denoted as D (Equation (4)). The total number of carbohydrate residues was determined again by dividing the change in $\mathrm{M}_{\mathrm{w}}$ upon deacylation from the PAMAM dendrimer, by the $\mathrm{M}_{\mathrm{w}}$ of the deacetylated tethered sugar (309 for galactose, 352 for galNAc and 471 for lactose), denoted by as E (Equation (5)). These three methods of determining the total sugar loading were then averaged, denoted as $\mathrm{F}$ (Equation (6)). The number of residues of the first sugar was the corrected by dividing $\mathrm{A}$ by $\mathrm{C}$ times $\mathrm{F}$ to give $\mathrm{A}^{\prime}$ as shown in Equation (7), to obtain the most accurate value for how many residues of the first isothiocyanato sugar (and also by difference for how many residues of the second isothiocyanato sugar) were added to the dendrimer. Sample numbers using data from compound $\mathbf{4} \mathbf{d}$ are provided in the equations below:

$$
\begin{gathered}
\mathrm{A}=\frac{\mathrm{Mw}(\text { all 1 addition })-\mathrm{Mw}(\mathrm{PAMAM})}{477}=\frac{15800-6800}{477}=18.9 \\
\mathrm{~B}=\frac{\mathrm{Mw}(\text { all } 2 \text { additions })-\mathrm{Mw}(\mathrm{PAMAM})}{765}=\frac{21800-15800}{765}=7.8 \\
\mathrm{D}=\frac{\mathrm{Mw}(\text { all RNCS added })-\mathrm{Mw}(\text { deacetylated })}{\left[\frac{(\mathrm{A} \times 168)+(\mathrm{B} \times 294)}{\mathrm{C}}\right]}=\frac{21800-15700}{\left[\frac{5469}{26.7}\right]}=29.8 \\
\mathrm{E}=\frac{\mathrm{Mw}(\text { deacetylated })-\mathrm{Mw}(\mathrm{PAMAM})}{\left[\frac{(\mathrm{A} \times 309)+(\mathrm{B} \times 471)}{\mathrm{C}}\right]}=\frac{15700-6800}{\left[\frac{9514}{26.7}\right]}=25.0 \\
\mathrm{~F}=\frac{(\mathrm{C}+\mathrm{D}+\mathrm{E})}{3}=27.1 \\
\mathrm{~A}^{\prime}=(\mathrm{A} / \mathrm{C}) \times \mathrm{F}=(18.9 / 26.7) \times 27.1=19.2 \\
\mathrm{~B}^{\prime}=(\mathrm{B} / \mathrm{C}) \times \mathrm{F}=(7.8 / 26.7) \times 27.1=7.9
\end{gathered}
$$

\section{3. $N M R$}

${ }^{1} \mathrm{H}-\mathrm{NMR}$ spectra were recorded on DPX 300 (300 MHz) and DPX-500 (500 MHz) spectrometers (Bruker). Chemical shifts are reported in ppm from tetramethylsilane with the residual protic solvent resonance as the internal standard (chloroform: $\delta 7.25 \mathrm{ppm}$; dimethyl sulfoxide: $\delta 2.50 \mathrm{ppm}$ ). Data are 
reported as follows: chemical shift, multiplicity $(\mathrm{s}=$ singlet, $\mathrm{bs}=$ broad singlet, $\mathrm{d}=$ doublet, $\mathrm{t}=$ triplet, $\mathrm{q}=$ quartet, $\mathrm{p}=$ pentet, $\mathrm{m}=$ multiplet, app = apparent), integration, coupling constants (in $\mathrm{Hz})$ and assignments. ${ }^{13} \mathrm{C}$-NMR spectra were recorded on a Bruker DPX 500 (125 MHz) spectrometer with complete proton decoupling. Chemical shifts are reported in ppm from tetramethylsilane with the solvent as the internal standard $\left(\mathrm{CDCl}_{3}: \delta 77.0 \mathrm{ppm}\right)$.

\subsection{Biotinylation of Galectin-1}

The biotinylated procedure was adopted and modified from the Thermo Scientific Instructions, EZ-Link ${ }^{\circledR}$ Sulfo-NHS-LC-Biotin. 21327, 1855.4 (2011). Biotinylation of galectin-1 was achieved with EZ-Link $^{\circledR}$ Sulfo-NHS-LC-Biotin (sulfosuccinimidyl-6-[biotin-amido]hexanoate) (Thermo Scientific ${ }^{\circledR}$, Waltham, MA, USA). A stock solution of Sulfo-NHS-LC-Biotin was prepared at $1 \mathrm{mg} / \mathrm{mL}$ in PBS (pH $7.4,15 \mathrm{mM} \mathrm{NaCl}$ ). To a solution of galectin-1 in PBS, the biotin reagent was added in an 8 molar excess, and the reaction was stirred at RT for $3 \mathrm{~h}$. After $3 \mathrm{~h}$, the reaction mixture was purified by dialysis against PBS ( $\mathrm{pH} 7.4,15 \mathrm{mM} \mathrm{NaCl}$ ) with a $1 \mathrm{kD}$ MWCO (Spectrum Laboratories, Inc., Houston, TX, USA, 6 Spectra/Por ${ }^{\circledR}$ Dialysis Membrane).

Quantitation of biotin loading was achieved with a Biotin Quantitation Kit (Pierce ${ }^{\circledR}$, Life Technologies, Thermo Scientific, Waltham, MA, USA) and spectrometric measurements were made using a SoftMax ${ }^{\circledR}$ Pro 5 SPECTRA max Plus 3.84 (Molecular Devices, Sunyvale, CA, USA, Serial No.: SMP500-14501-EARG). To a $1 \mathrm{~mL}$ cuvette (PLASTIBRAND ${ }^{\circledR}$, Thermo Scientific, Waltham, MA, USA), $800 \mu \mathrm{L}$ of PBS buffer ( $\mathrm{pH} 7.4,15 \mathrm{mM} \mathrm{NaCl}$ ) was added and the spectrophotometer was zeroed at $500 \mathrm{~nm}$. To a microtube of 4'-hydroxyazobenzene-2-carboxylic acid (HABA)/Avidin Premix, equilibrated to room temperature $\left(66.7^{\circ} \mathrm{C}\right), 100 \mu \mathrm{L}$ of millipore $\mathrm{H}_{2} \mathrm{O}$ was added and mixed with a pipette until solubilization. The HABA/Avidin Premix solution was added to the $1 \mathrm{~mL}$ cuvette containing the PBS buffer and mixed. The absorbance of the HABA/Avidin solution was measured at $500 \mathrm{~nm}(\mathrm{~A} 500 \mathrm{H} / \mathrm{A})$. To the cuvette, $100 \mu \mathrm{L}$ of biotinylated galectin-1 was then added and mixed thoroughly. The absorbance of the HABA/Avidin/biotinylated galectin-1 mixture was measured at $500 \mathrm{~nm}$ (A500 H/A/B-Gal-1. From the change in absorbance at $500 \mathrm{~nm}$, the number of moles of biotin per mole of galectin-1 was calculated using Beer's Law, to yield 5 moles biotin per galectin-1.

\subsection{Synthesis Protocols}

\subsubsection{Synthesis of Compounds $\mathbf{1}$ and $\mathbf{3}$}

Compounds $\mathbf{1}$ and $\mathbf{3}$ were synthesized as shown in Scheme 2.

1-O-(5-Isothiocyanato-3-oxopentyl)-2,3,4,6-tetra-O-acetyl- $\beta$-D-galactopyranoside (1). 1,2,3,4,6-Penta$O$-acetyl- $\beta$-D-galactopyranoside $(2.0 \mathrm{~g}, 5.1 \mathrm{mmol})$ was dissolved in methylene chloride $(50 \mathrm{~mL})$ with 2-(2-isothiocyantoethoxy)ethanol $(1.5 \mathrm{~g}, 10.2 \mathrm{mmol})$ and cooled to $0{ }^{\circ} \mathrm{C}$ followed by addition of $\mathrm{BF}_{3} \mathrm{OEt}_{2}(1.4 \mathrm{~g}, 10.2 \mathrm{mmol})$ via syringe pump over $30 \mathrm{~min}$. The reaction was stirred for $1 \mathrm{~h}$, at which point $\mathrm{NaHCO}_{3}(1 \mathrm{~g})$ was added. The mixture was filtered over Celite and solvent was removed in vacuo. The residue was purified via column chromatography with a 1:1 ethyl acetate-hexane eluent ( $\left.\mathrm{R}_{\mathrm{f}} 0.25\right)$, yielding $1.8 \mathrm{~g}\left(76 \%\right.$ yield) of pure material. ${ }^{1} \mathrm{H}-\mathrm{NMR}\left(300 \mathrm{MHz}, \mathrm{CDCl}_{3}\right) \delta 5.38(1 \mathrm{H}$, d, 
$J=2.1 \mathrm{~Hz}, \mathrm{H} 4), 5.19(1 \mathrm{H}$, app t $, J=7.8 \mathrm{~Hz}, \mathrm{H} 2), 5.02(1 \mathrm{H}, \mathrm{dd}, J=2.1,10.1 \mathrm{~Hz}, \mathrm{H} 3), 4.55(1 \mathrm{H}, \mathrm{d}$, $J=7.8 \mathrm{~Hz}, \mathrm{H1}), 4.11$ (2H, m, H5), 3.95 (2H, m, H6), $3.68(7 \mathrm{H}, \mathrm{m}), 2.19(3 \mathrm{H}, \mathrm{s}), 2.05$ (3H, s), 2.03 $(3 \mathrm{H}, \mathrm{s}), 1.96(3 \mathrm{H}, \mathrm{s}) \mathrm{ppm}$. As reported [86].
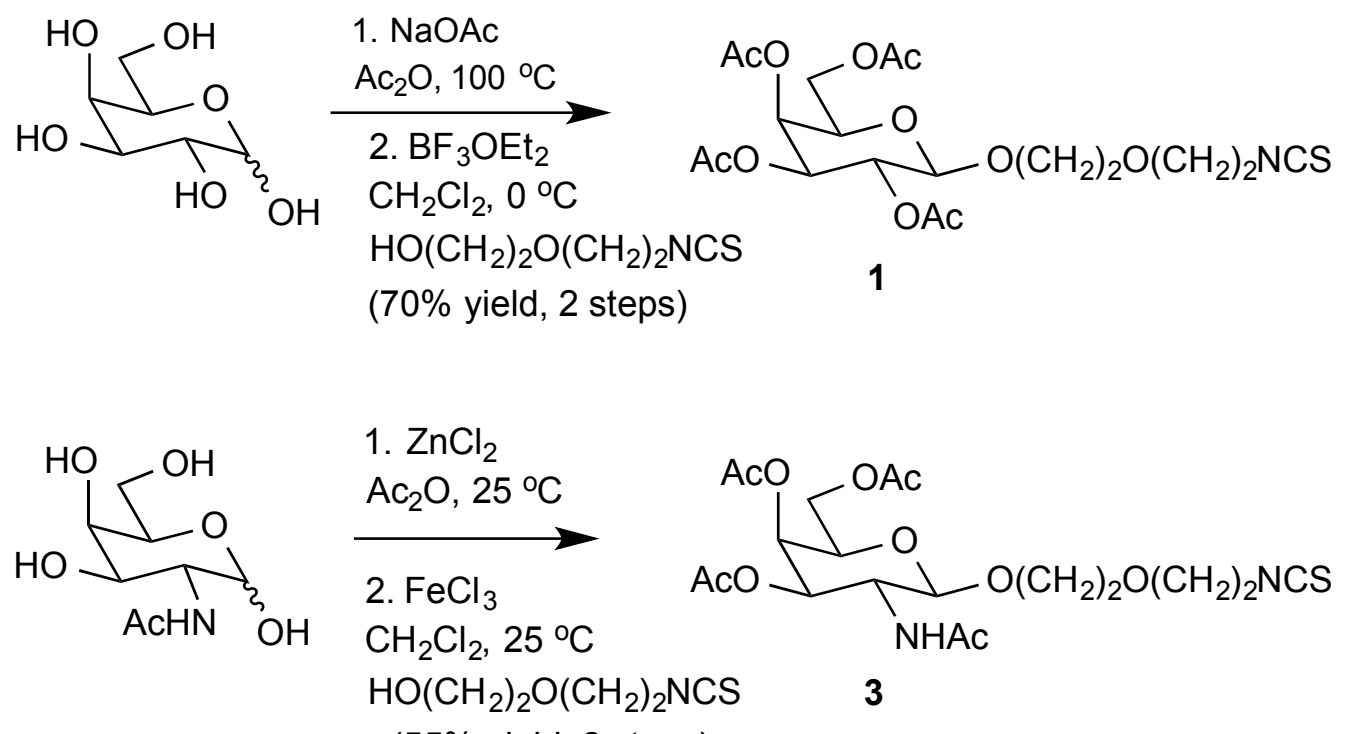

(55\% yield, 2 steps)

Scheme 2. Synthesis of isothiocyanato-functionalized galactose $\mathbf{1}$ and galNAc $\mathbf{3}$.

1-O-(5-Isothiocyanato-3-oxopentyl)-2,3,4,6-tetra-O-acetyl- $\beta$-D-galactosaminopyranoside (3). $0.94 \mathrm{~g}$ of 1,3,4,6-penta- $O$-acetyl- $\beta$-D- $N$-acetyl-galactaminopyranoside $(2.4 \mathrm{mmol})$ was dissolved in $15 \mathrm{~mL}$ of methylene chloride, $1.4 \mathrm{~g}$ of dririte was added, the slurry stirred for $10 \mathrm{~min}$ and $1.4 \mathrm{~g}$ of $\mathrm{FeCl}_{3}(10.2$ $\mathrm{mmol})$ and $0.83 \mathrm{~g}$ of 2-(2-isothiocyantoethoxy)ethanol $(5.7 \mathrm{mmol})$ were added. The reaction was stirred $24 \mathrm{~h}$, then $1 \mathrm{~g}$ of $\mathrm{NaHCO}_{3}$ was added. The mixture was filtered over celite and solvent was removed in vacuo. The residue was purified via column chromatography with a 9:1 ethyl acetate-hexane eluant $\left(\mathrm{R}_{\mathrm{f}} 0.4\right)$, yielding 0.70 grams of pure material. ${ }^{1} \mathrm{H}-\mathrm{NMR}\left(500 \mathrm{MHz} \mathrm{DMSO}-d_{6}\right) \delta 7.83(1 \mathrm{H}$, d, $J=9.2 \mathrm{~Hz}, \mathrm{NHAc}), 5.21(1 \mathrm{H}, \mathrm{d}, J=3.0 \mathrm{~Hz}, \mathrm{H} 4), 4.97(1 \mathrm{H}, \mathrm{dd}, J=3.0,11.2 \mathrm{~Hz}, \mathrm{H} 3), 4.55(1 \mathrm{H}, \mathrm{d}$, $J=9.5 \mathrm{~Hz}, \mathrm{H} 1), 4.02\left(3 \mathrm{H}, \mathrm{m}, \mathrm{H} 5, \mathrm{OCH}_{2} \mathrm{CH}_{2} \mathrm{O}\right), 3.87(1 \mathrm{H}$, app q, $J=9.2$ (NHAc), 9.5, $11.2 \mathrm{~Hz}, \mathrm{H} 2)$, $3.80\left(2 \mathrm{H}, \mathrm{t}, J=4.9 \mathrm{~Hz}, \mathrm{OCH}_{2} \mathrm{CH}_{2} \mathrm{NCS}\right), 3.59$ (6H, m, H6, $\left.\mathrm{CH}_{2} \mathrm{CH}_{2} \mathrm{OCH}_{2} \mathrm{CH}_{2}\right), 2.11(3 \mathrm{H}, \mathrm{s}), 2.04(3 \mathrm{H}, \mathrm{s})$, $1.89(3 \mathrm{H}, \mathrm{s}), 1.78(3 \mathrm{H}, \mathrm{s}) \mathrm{ppm}$. As reported [87].

3.5.2. Representative Procedure for the Synthesis of Acetyl Protected Lactose and Galactose Functionalized Dendrimers

An aqueous solution of amine terminated G(4)-PAMAM dendrimer (2.478 $\mathrm{g}$ of a $17 \% \mathrm{w} / \mathrm{w}$ solution in water, $421.2 \mathrm{mg}, 31.2 \mu \mathrm{mol})$ was lyophilized to leave a foamy residue. DMSO $(7.02 \mathrm{~mL})$ was added to this residue to give a $60 \mathrm{mg} / \mathrm{mL}$ solution. A $300 \mathrm{mM}$ solution of $1(0.31 \mathrm{~mL}, 73 \mu \mathrm{mol}, 35 \mathrm{mg}) \mathrm{was}$ added to the $60 \mathrm{mg} / \mathrm{mL}$ G(4) PAMAM dendrimer solution $(0.5 \mathrm{~mL}, 30 \mathrm{mg}, 4.40 \mu \mathrm{mol})$. The reaction was stirred for $8 \mathrm{~h}$ at which point a $75 \mu \mathrm{L}$ aliquot was removed for MALDI-TOF analysis. After MALDI-TOF analysis indicated reaction completion, a $300 \mathrm{mM}$ solution of $2(0.35 \mathrm{~mL}, 85 \mu \mathrm{mol}, 40.2 \mathrm{mg})$ in DMSO was added. The solution was then stirred for $8 \mathrm{~h}$, lyophilized, and directly subjected to deacetylation conditions. The amounts of reagents used for individual compounds are listed in Table 4. 
Table 4. Amounts used in synthesis of peracetylated pre-compounds $\mathbf{4 a - 6 f}$.

\begin{tabular}{ccccc}
\hline $\begin{array}{c}\text { Compound } \\
\text { Number }\end{array}$ & $\begin{array}{c}\text { PAMAM } \\
\text { Generation }\end{array}$ & $\begin{array}{c}\text { PAMAM } \\
(\boldsymbol{\mu m o l})\end{array}$ & $\begin{array}{c}\text { Galactose }(\boldsymbol{\mu m o l}) \\
\left(\mathbf{0}^{\mathbf{a}}\right)\end{array}$ & $\begin{array}{c}\text { Lactose }(\boldsymbol{\mu m o l}) \\
\left(\mathbf{p}^{\mathbf{a}}\right)\end{array}$ \\
\hline $\mathbf{4 a}$ & 3 & 4.4 & 0 & 140.8 \\
$\mathbf{4 b}$ & 3 & 4.4 & 28.2 & 112.6 \\
$\mathbf{4 c}$ & 3 & 4.4 & 56.3 & 84.5 \\
$\mathbf{4 d}$ & 3 & 4.4 & 84.5 & 56.3 \\
$\mathbf{4 e}$ & 3 & 4.4 & 112.6 & 28.2 \\
$\mathbf{4 f}$ & 3 & 4.4 & 140.8 & 0 \\
$\mathbf{5 a}$ & 4 & 2.2 & 0 & 140.8 \\
$\mathbf{5 b}$ & 4 & 2.2 & 28.2 & 112.6 \\
$\mathbf{5 c}$ & 4 & 2.2 & 56.3 & 84.5 \\
$\mathbf{5 d}$ & 4 & 2.2 & 84.5 & 56.3 \\
$\mathbf{5 e}$ & 4 & 2.2 & 112.6 & 28.2 \\
$\mathbf{5 f}$ & 4 & 2.2 & 140.8 & 0 \\
$\mathbf{6 a}$ & 6 & 0.5 & 0 & 120.0 \\
$\mathbf{6 b}$ & 6 & 0.5 & 24.0 & 96.0 \\
$\mathbf{6 c}$ & 6 & 0.5 & 48.0 & 72.0 \\
$\mathbf{6 d}$ & 6 & 0.5 & 72.0 & 48.0 \\
$\mathbf{6 e}$ & 6 & 0.5 & 96.0 & 24.0 \\
$\mathbf{6 f}$ & 6 & 0.5 & 120.0 & 0 \\
\hline
\end{tabular}

${ }^{a}$ Values for o and $\mathrm{p}$ (as shown in Scheme 1 of the primary manuscript) derive directly from the $\mu$ mol values shown here.

\subsubsection{General Deacetylation Procedure to Afford Dendrimers 4-6}

To the lyophilized solid peracetylated dendrimers, 1:1 water-methanol $(1 \mathrm{~mL})$ was added, at which point the dendrimer became a white precipitate. To this mixture was added $\mathrm{NaOMe}(0.2$ equivalents, $0.8 \mathrm{M}$ in $\mathrm{MeOH}$ ) for each peripheral carbohydrate, and it was allowed to stir for $3 \mathrm{~h}$. If, at this time, the mixture had not become a clear solution, a further 0.2 equivalents of $\mathrm{NaOMe}(0.8 \mathrm{M}$ in $\mathrm{MeOH})$ was added, and this step was repeated until the mixture became a clear and colorless solution. Aqueous $\mathrm{HCl}$ solution $(0.1 \mathrm{M})$ was then added slowly until the $\mathrm{pH}$ was $\sim 7$. This neutralized solution was placed in a dialysis membrane (MW cutoff 3,500 Da) and dialyzed in $1 \mathrm{~L}$ of DI water for $8 \mathrm{~h}$. The water was changed and let stand for a further $8 \mathrm{~h}$ twice more. The remaining liquid in the membrane was frozen and lyophilized to give a white fluffy solid. Compounds were characterized with ${ }^{1} \mathrm{H}-\mathrm{NMR}$ and MALDI-TOF MS. MALDI-TOF MS data is summarized in Table 5.

\subsubsection{Spectroscopic Data for Compounds 4-6}

4a: ${ }^{1} \mathrm{H}-\mathrm{NMR}\left(500 \mathrm{MHz} d_{6}\right.$-DMSO) $\delta 7.97(1 \mathrm{H}, \mathrm{bs}), 7.78(0.9 \mathrm{H}, \mathrm{bs}), 7.47$ (1.5H, bs), 5.17 (1.3H, s), $5.11(2.4 \mathrm{H}, \mathrm{m}), 4.79(1.5 \mathrm{H}$, app t, $J=9.0 \mathrm{~Hz}), 4.69(2.2 \mathrm{H}, \mathrm{m}), 4.62(1.1 \mathrm{H}, J=9.0 \mathrm{~Hz}), 4.25(1.2 \mathrm{H}, \mathrm{d}$, $J=11.3 \mathrm{~Hz}), 4.16(1.4 \mathrm{H}, \mathrm{m}), 3.97(4.3 \mathrm{H}, \mathrm{m}), 3.74(3.7 \mathrm{H}, \mathrm{m}), 3.56(2.5 \mathrm{H}, \mathrm{bs}), 3.12(2.7 \mathrm{H}, \mathrm{bs}), 3.04$ (2.0H, bs), $2.64(5.7 \mathrm{H}, \mathrm{bs}), 2.16(4.4 \mathrm{H}, \mathrm{bs}), 2.04(4.3 \mathrm{H}, \mathrm{s}), 2.02(4.8 \mathrm{H}, \mathrm{s}), 1.95(8.9 \mathrm{H}, \mathrm{s}), 1.92(7.3 \mathrm{H}$, s), 1.84 (3.9H, s) ppm. MALDI-TOF (pos) $m / z$ 24,400. 
Table 5. MALDI-TOF MS data for heterogeneously functionalized dendrimers $4 \mathbf{a}-\mathbf{f}, \mathbf{5 a}-\mathbf{f}$ and $\mathbf{6 a}-\mathbf{f}$.

\begin{tabular}{cccc}
\hline Compound Number & $\mathbf{M}_{\mathbf{w}}$ after Galactose Addition & $\mathbf{M}_{\mathbf{w}}$ after Lactose Addition & $\mathbf{M}_{\mathbf{w}}$ after Deacylation \\
\hline $\mathbf{4 a}$ & 6800 & 24,400 & 15,000 \\
$\mathbf{4 b}$ & 10,200 & 24,600 & 15,100 \\
$\mathbf{4 c}$ & 13,300 & 22,200 & 14,900 \\
$\mathbf{4 d}$ & 15,800 & 21,800 & 15,700 \\
$\mathbf{4 e}$ & 18,400 & 20,500 & 15,800 \\
$\mathbf{4 f}$ & 19,500 & 6800 & 15,200 \\
$\mathbf{5 a}$ & 13,500 & 54,500 & 31,200 \\
$\mathbf{5 b}$ & 21,200 & 48,000 & 31,700 \\
$\mathbf{5 c}$ & 26,700 & 45,400 & 33,000 \\
$\mathbf{5 d}$ & 30,500 & 41,700 & 34,300 \\
$\mathbf{5 e}$ & 35,500 & 41,000 & 34,300 \\
$\mathbf{5 f}$ & 40,900 & 13,500 & 31,500 \\
$\mathbf{6}$ & 51,000 & 147,000 & 100,000 \\
$\mathbf{6 b}$ & 68,000 & 144,000 & 101,000 \\
$\mathbf{6 c}$ & 78,500 & 140,500 & 101,500 \\
$\mathbf{6 d}$ & 90,500 & 132,500 & 102,000 \\
$\mathbf{6 e}$ & 102,000 & 131,500 & 106,500 \\
$\mathbf{6 f}$ & 122,000 & 51,000 & 101,000 \\
\hline
\end{tabular}

4b: ${ }^{1} \mathrm{H}-\mathrm{NMR}$ (500 MHz d6-DMSO) $\delta 7.95$ (1H, bs), 7.75 (1.1H, bs), 7.47 (2H, bs), 5.21 (0.4H, s), 5.17 $(1.3 \mathrm{H}, \mathrm{s}), 5.12(2.6 \mathrm{H}, \mathrm{m}), 4.89(0.4 \mathrm{H}, \mathrm{m}), 4.79(1.5 \mathrm{H}$, app t, $J=9.0 \mathrm{~Hz}), 4.69(2.4 \mathrm{H}, \mathrm{m}), 4.62(1.1 \mathrm{H}$, $J=9.0 \mathrm{~Hz}), 4.25(1.2 \mathrm{H}, \mathrm{d}, J=11.3 \mathrm{~Hz}), 4.16(1.7 \mathrm{H}, \mathrm{m}), 3.98(4.8 \mathrm{H}, \mathrm{m}), 3.74(4.1 \mathrm{H}, \mathrm{m}), 3.40-3.56$ $(16 \mathrm{H}, \mathrm{m}), 3.13(3.2 \mathrm{H}, \mathrm{bs}), 3.04(2.3 \mathrm{H}, \mathrm{bs}), 2.64(5.9 \mathrm{H}, \mathrm{bs}), 2.16(4.2 \mathrm{H}, \mathrm{bs}), 2.07(1.2 \mathrm{H}, \mathrm{s}), 2.05(3.6 \mathrm{H}$, s), $2.03(3.1 \mathrm{H}, \mathrm{s}), 1.96(10.2 \mathrm{H}, \mathrm{s}), 1.92(6.2 \mathrm{H}, \mathrm{s}), 1.87(1.2 \mathrm{H}, \mathrm{s}), 1.84(3.9 \mathrm{H}, \mathrm{s}) \mathrm{ppm}$. MALDI-TOF (pos) $m / z 24,600$.

4c: ${ }^{1} \mathrm{H}-\mathrm{NMR}$ (500 MHz d6-DMSO) $\delta 7.96$ (1H, bs), 7.75 (1.1H, bs), 7.47 (1.9H, bs), 5.21 (0.6H, s), $5.17(0.9 \mathrm{H}, \mathrm{s}), 5.12(1.8 \mathrm{H}, \mathrm{m}), 4.89(0.6 \mathrm{H}$, app t, $J=9.1 \mathrm{~Hz}), 4.79(0.9 \mathrm{H}$, app t, $J=9.0 \mathrm{~Hz}), 4.69$ $(1.8 \mathrm{H}, \mathrm{m}), 4.62(0.6 \mathrm{H}, J=9.0 \mathrm{~Hz}), 4.25(0.7 \mathrm{H}, \mathrm{d}, J=11.3 \mathrm{~Hz}), 4.17(1.5 \mathrm{H}, \mathrm{m}), 3.98(3.8 \mathrm{H}, \mathrm{m}), 3.74$ (3.2H, m), 3.40-3.56 (20H, m), $3.13(2.7 \mathrm{H}, \mathrm{bs}), 3.04(2.3 \mathrm{H}, \mathrm{bs}), 2.64$ (4.4H, bs), 2.37 (2.9H, bs), 2.16 $(4.1 \mathrm{H}, \mathrm{bs}), 2.07(1.9 \mathrm{H}, \mathrm{s}), 2.05(2.1 \mathrm{H}, \mathrm{s}), 2.03(2.5 \mathrm{H}, \mathrm{s}), 1.95(8.4 \mathrm{H}, \mathrm{s}), 1.92(4.6 \mathrm{H}, \mathrm{s}), 1.87(1.5 \mathrm{H}, \mathrm{s})$, $1.85(2.3 \mathrm{H}, \mathrm{s})$ ppm. MALDI-TOF (pos) $\mathrm{m} / z$ 22,200.

4d: ${ }^{1} \mathrm{H}-\mathrm{NMR}\left(500 \mathrm{MHz} d_{6}\right.$-DMSO) $\delta 7.96(1 \mathrm{H}, \mathrm{bs}), 7.75(0.9 \mathrm{H}, \mathrm{bs}), 7.47(1.7 \mathrm{H}, \mathrm{bs}), 5.21(0.7 \mathrm{H}, \mathrm{d}$, $J=3.1 \mathrm{~Hz}), 5.17(0.5 \mathrm{H}, \mathrm{s}), 5.12(1.5 \mathrm{H}, \mathrm{m}), 4.89(0.7 \mathrm{H}$, app t, $J=9.1 \mathrm{~Hz}), 4.79(0.5 \mathrm{H}$, app t, $J=9.0 \mathrm{~Hz})$, $4.69(1.3 \mathrm{H}, \mathrm{m}), 4.62(0.4 \mathrm{H}, J=9.0 \mathrm{~Hz}), 4.25(0.4 \mathrm{H}, \mathrm{d}, J=11.3 \mathrm{~Hz}), 4.17(1.2 \mathrm{H}, \mathrm{m}), 3.98(3 \mathrm{H}, \mathrm{m})$, $3.74(2.3 \mathrm{H}, \mathrm{m}), 3.40-3.56(13 \mathrm{H}, \mathrm{m}), 3.13(2.5 \mathrm{H}, \mathrm{bs}), 3.04(1.8 \mathrm{H}, \mathrm{bs}), 2.64(3.8 \mathrm{H}, \mathrm{bs}), 2.37(2.1 \mathrm{H}, \mathrm{bs})$, $2.16(3.5 \mathrm{H}, \mathrm{bs}), 2.07(2.2 \mathrm{H}, \mathrm{s}), 2.05(1.2 \mathrm{H}, \mathrm{s}), 2.03(2.3 \mathrm{H}, \mathrm{s}), 1.95(4.9 \mathrm{H}, \mathrm{s}), 1.92(2.2 \mathrm{H}, \mathrm{s}), 1.87(1.6 \mathrm{H}$, s), $1.85(1.3 \mathrm{H}, \mathrm{s})$ ppm. MALDI-TOF (pos) $\mathrm{m} / \mathrm{z} 21,800$.

4e: ${ }^{1} \mathrm{H}-\mathrm{NMR}\left(500 \mathrm{MHz} d_{6}\right.$-DMSO) $\delta 7.96$ (1H, bs), 7.75 (0.9H, bs), 7.47 (1.7H, bs), 5.21 (0.9H, s), $5.17(0.2 \mathrm{H}, \mathrm{s}), 5.12(1.3 \mathrm{H}, \mathrm{m}), 4.89(0.9 \mathrm{H}$, app t, $J=9.1 \mathrm{~Hz}), 4.79(0.2 \mathrm{H}$, app t, $J=9.0 \mathrm{~Hz}), 4.69$ $(1.1 \mathrm{H}, \mathrm{m}), 4.62(0.2 \mathrm{H}, J=9.0 \mathrm{~Hz}), 4.25(0.2 \mathrm{H}, \mathrm{d}, J=11.3 \mathrm{~Hz}), 4.17(1.2 \mathrm{H}, \mathrm{m}), 3.98(2.6 \mathrm{H}, \mathrm{m}), 3.74(1.9 \mathrm{H}$, 
m), 3.40-3.56 (13H, m), $3.13(2.7 \mathrm{H}, \mathrm{bs}), 3.04$ (1.7H, bs), 2.64 (5H, bs), 2.37 (3H, bs), 2.16 (3.6H, bs), 2.07 $(2.7 \mathrm{H}, \mathrm{s}), 2.05(0.7 \mathrm{H}, \mathrm{s}), 2.03(0.6 \mathrm{H}, \mathrm{s}), 1.95(6.9 \mathrm{H}, \mathrm{s}), 1.92(1.4 \mathrm{H}, \mathrm{s}), 1.87(3 \mathrm{H}, \mathrm{s}) \mathrm{ppm}$. MALDI-TOF (pos) $m / z 20,500$.

4f: ${ }^{1} \mathrm{H}-\mathrm{NMR}\left(500 \mathrm{MHz} d_{6}\right.$-DMSO) $\delta 7.95(1 \mathrm{H}, \mathrm{bs}$, amide NH's), $7.74(1 \mathrm{H}, \mathrm{bs}$, amide NH's), 7.46 (2H, bs, $\left.\mathrm{CH}_{2} \mathrm{~N} H C(\mathrm{~S}) \mathrm{NHCH}_{2}\right), 5.21(1.3 \mathrm{H}, \mathrm{d}, J=3.2 \mathrm{~Hz}, \mathrm{H} 4), 5.11(1.3 \mathrm{H}, \mathrm{dd}, J=3.2,10.3 \mathrm{~Hz}, \mathrm{H} 3), 4.89$ $(1.3 \mathrm{H}, \mathrm{dd}, J=8.1,10.3 \mathrm{~Hz}, \mathrm{H} 2), 4.69(1.3 \mathrm{H}, \mathrm{d}, J=8.1 \mathrm{~Hz}, \mathrm{H} 1), 4.12(1.3 \mathrm{H}, \mathrm{d}, J=6.1 \mathrm{~Hz}$, $\left.\mathrm{OCH}_{2} \mathrm{CH}_{2} \mathrm{O}\right), 4.01(2.6 \mathrm{H}, \mathrm{m}), 3.76(1.3 \mathrm{H}, \mathrm{m}), 3.59(1.3 \mathrm{H}, \mathrm{m}), 3.27-3.52(12 \mathrm{H}, \mathrm{m}), 3.13(3 \mathrm{H}, \mathrm{bs}), 3.04$ $(2.2 \mathrm{H}, \mathrm{bs}), 2.61(4.8 \mathrm{H}, \mathrm{m}), 2.39(3.2 \mathrm{H}, \mathrm{m}), 2.16(4.8 \mathrm{H}, \mathrm{bs}), 2.08(4 \mathrm{H}, \mathrm{s}), 2.00(4 \mathrm{H}, \mathrm{s}), 1.96(4 \mathrm{H}, \mathrm{s}), 1.87$ (4H, s) ppm. MALDI-TOF (pos) $m / z$ 19,500.

5a: ${ }^{1} \mathrm{H}-\mathrm{NMR}\left(500 \mathrm{MHz} d_{6}-\mathrm{DMSO}\right) \delta 7.95(1 \mathrm{H}, \mathrm{bs}), 7.78(0.8 \mathrm{H}, \mathrm{bs}), 7.47$ (1.9H, bs), 5.17 (1.7H, s), $5.11(2.8 \mathrm{H}, \mathrm{m}), 4.79(1.7 \mathrm{H}$, app t, $J=9.0 \mathrm{~Hz}), 4.69(2.5 \mathrm{H}, \mathrm{m}), 4.62(1.2 \mathrm{H}, J=9.0 \mathrm{~Hz}), 4.25(1.4 \mathrm{H}, \mathrm{d}$, $J=10.8 \mathrm{~Hz}), 4.16(1.6 \mathrm{H}, \mathrm{m}), 3.97(4.9 \mathrm{H}, \mathrm{m}), 3.74(4.4 \mathrm{H}, \mathrm{m}), 3.40-3.56(10 \mathrm{H}, \mathrm{m}), 3.12(2.7 \mathrm{H}, \mathrm{bs})$, $3.04(1.4 \mathrm{H}, \mathrm{bs}), 2.64(4.9 \mathrm{H}, \mathrm{bs}), 2.16(3.8 \mathrm{H}, \mathrm{bs}), 2.04(5.2 \mathrm{H}, \mathrm{s}), 2.02(4.7 \mathrm{H}, \mathrm{s}), 1.95(10.5 \mathrm{H}, \mathrm{s}), 1.92$ (7.4H, s), $1.84(4.6 \mathrm{H}, \mathrm{s}) \mathrm{ppm}$. MALDI-TOF (pos) $\mathrm{m} / \mathrm{z} 54,500$.

5b: ${ }^{1} \mathrm{H}-\mathrm{NMR}\left(500 \mathrm{MHz} d_{6}\right.$-DMSO) $\delta 7.95$ (1H, bs), 7.75 (1H, bs), 7.47 (1.7H, bs), $5.21(0.3 \mathrm{H}, \mathrm{s}), 5.17$ $(1.1 \mathrm{H}, \mathrm{s}), 5.12(2.1 \mathrm{H}, \mathrm{m}), 4.89(0.3 \mathrm{H}, \mathrm{m}), 4.79(1.1 \mathrm{H}$, app t, $J=9.0 \mathrm{~Hz}), 4.69(1.9 \mathrm{H}, \mathrm{m}), 4.62(0.8 \mathrm{H}$, $J=9.0 \mathrm{~Hz}), 4.25(1 \mathrm{H}, \mathrm{d}, J=11.3 \mathrm{~Hz}), 4.16(1.3 \mathrm{H}, \mathrm{m}), 3.98(3.8 \mathrm{H}, \mathrm{m}), 3.74(3.2 \mathrm{H}, \mathrm{m}), 3.40-3.56(10 \mathrm{H}$, m), $3.13(2.7 \mathrm{H}, \mathrm{bs}), 3.04(2.1 \mathrm{H}, \mathrm{bs}), 2.64(5.7 \mathrm{H}, \mathrm{bs}), 2.16(3.9 \mathrm{H}, \mathrm{bs}), 2.07(1.1 \mathrm{H}, \mathrm{s}), 2.05(2.7 \mathrm{H}, \mathrm{s})$, $2.03(3 \mathrm{H}, \mathrm{s}), 1.96(8.2 \mathrm{H}, \mathrm{s}), 1.92(4.5 \mathrm{H}, \mathrm{s}), 1.87(1 \mathrm{H}, \mathrm{s}), 1.84(2.5 \mathrm{H}, \mathrm{s}) \mathrm{ppm}$. MALDI-TOF (pos) $\mathrm{m} / \mathrm{z}$ 48,000 .

5c: ${ }^{1} \mathrm{H}-\mathrm{NMR}\left(500 \mathrm{MHz} d_{6}\right.$-DMSO) $\delta 7.96$ (1H, bs), 7.75 (1H, bs), 7.46 (1.7H, bs), 5.21 (0.5H, s), 5.17 $(0.8 \mathrm{H}, \mathrm{s}), 5.12(1.8 \mathrm{H}, \mathrm{m}), 4.89(0.5 \mathrm{H}$, app t, $J=9.1 \mathrm{~Hz}), 4.79(0.8 \mathrm{H}$, app t, $J=9.0 \mathrm{~Hz}), 4.69(1.6 \mathrm{H}, \mathrm{m})$, $4.62(0.6 \mathrm{H}, J=9.0 \mathrm{~Hz}), 4.25(0.7 \mathrm{H}, \mathrm{d}, J=11.3 \mathrm{~Hz}), 4.17(1.3 \mathrm{H}, \mathrm{m}), 3.98(3.5 \mathrm{H}, \mathrm{m}), 3.74(2.8 \mathrm{H}, \mathrm{m})$, 3.40-3.56 (10H, m), 3.13 (2.5H, bs), 3.04 (2H, bs), 2.64 (4.9H, bs), 2.37 (2.3H, bs), 2.16 (4H, bs), 2.07 $(1.6 \mathrm{H}, \mathrm{s}), 2.05(2.2 \mathrm{H}, \mathrm{s}), 2.03(1.8 \mathrm{H}, \mathrm{s}), 1.95(7.8 \mathrm{H}, \mathrm{s}), 1.92(3.5 \mathrm{H}, \mathrm{s}), 1.87(1.4 \mathrm{H}, \mathrm{s}), 1.85(1.8 \mathrm{H}, \mathrm{s})$ ppm. MALDI-TOF (pos) $\mathrm{m} / \mathrm{z}$ 45,500.

5d: ${ }^{1} \mathrm{H}-\mathrm{NMR}\left(500 \mathrm{MHz} d_{6}\right.$-DMSO) $\delta 7.96$ (1H, bs), 7.75 (0.9H, bs), 7.47 (1.9H, bs), 5.21 (0.8H, d, $J=3.1 \mathrm{~Hz}), 5.17(0.6 \mathrm{H}, \mathrm{s}), 5.12(1.7 \mathrm{H}, \mathrm{m}), 4.89(0.7 \mathrm{H}$, app t, $J=9.1 \mathrm{~Hz}), 4.79(0.5 \mathrm{H}$, app t, $J=9.0 \mathrm{~Hz})$, $4.69(1.5 \mathrm{H}, \mathrm{m}), 4.62(0.4 \mathrm{H}, J=9.0 \mathrm{~Hz}), 4.25(0.4 \mathrm{H}, \mathrm{d}, J=11.3 \mathrm{~Hz}), 4.17(1.4 \mathrm{H}, \mathrm{m}), 3.98(3.2 \mathrm{H}, \mathrm{m})$, $3.74(2.6 \mathrm{H}, \mathrm{m}), 3.40-3.56(10 \mathrm{H}, \mathrm{m}), 3.13(2.6 \mathrm{H}, \mathrm{bs}), 3.04(2.1 \mathrm{H}, \mathrm{bs}), 2.64(6.2 \mathrm{H}, \mathrm{bs}), 2.37(3 \mathrm{H}, \mathrm{bs})$, $2.16(3.9 \mathrm{H}, \mathrm{bs}), 2.07(2.2 \mathrm{H}, \mathrm{s}), 2.05(1.4 \mathrm{H}, \mathrm{s}), 2.03(1.2 \mathrm{H}, \mathrm{s}), 1.95(8.3 \mathrm{H}, \mathrm{s}), 1.92(2.5 \mathrm{H}, \mathrm{s}), 1.87(1.9 \mathrm{H}$, s), $1.85(1.5 \mathrm{H}, \mathrm{s})$ ppm. MALDI-TOF (pos) $m / z$ 41,500.

5e: ${ }^{1} \mathrm{H}-\mathrm{NMR}(500 \mathrm{MHz} d 6$-DMSO) $\delta 7.96(1 \mathrm{H}, \mathrm{bs}), 7.75(0.9 \mathrm{H}, \mathrm{bs}), 7.47$ (2H, bs), 5.21 (1H, s), 5.17 $(0.3 \mathrm{H}, \mathrm{s}), 5.12(1.5 \mathrm{H}, \mathrm{m}), 4.89(1 \mathrm{H}$, app t, $J=9.1 \mathrm{~Hz}), 4.79(0.2 \mathrm{H}$, app t, $J=9.0 \mathrm{~Hz}), 4.69(1 \mathrm{H}, \mathrm{m})$, $4.62(0.2 \mathrm{H}, J=9.0 \mathrm{~Hz}), 4.25(0.3 \mathrm{H}, \mathrm{d}, J=11.3 \mathrm{~Hz}), 4.17(1 \mathrm{H}, \mathrm{m}), 3.98(2.9 \mathrm{H}, \mathrm{m}), 3.74(2.1 \mathrm{H}, \mathrm{m})$, 3.40-3.56 (12H, m), $3.13(2.7 \mathrm{H}, \mathrm{bs}), 3.04(1.9 \mathrm{H}, \mathrm{bs}), 2.64(5.2 \mathrm{H}, \mathrm{bs}), 2.37$ (2.8H, bs), 2.16 (4.3H, bs), 
$2.07(2.8 \mathrm{H}, \mathrm{s}), 2.05(1 \mathrm{H}, \mathrm{s}), 2.03(0.9 \mathrm{H}, \mathrm{s}), 1.95(8.8 \mathrm{H}, \mathrm{s}), 1.92(1.5 \mathrm{H}, \mathrm{s}), 1.87(2.5 \mathrm{H}, \mathrm{s}) \mathrm{ppm}$. MALDI-TOF (pos) $\mathrm{m} / z 41000$.

5f: ${ }^{1} \mathrm{H}-\mathrm{NMR}\left(500 \mathrm{MHz} d_{6}\right.$-DMSO) $\delta 7.94$ (1H, bs, amide NH's), 7.73 (1H, bs, amide NH's), 7.45 (2H, bs, $\left.\mathrm{CH}_{2} \mathrm{NHC}(\mathrm{S}) \mathrm{NHCH}_{2}\right), 5.21(1.3 \mathrm{H}, \mathrm{s}, \mathrm{H} 4), 5.11(1.3 \mathrm{H}, \mathrm{d}, J=10.3 \mathrm{~Hz}, \mathrm{H} 3), 4.89(1.3 \mathrm{H}, \mathrm{m}, \mathrm{H} 2), 4.69$ $(1.3 \mathrm{H}, \mathrm{m}, \mathrm{H1}), 4.13\left(1.3 \mathrm{H}, \mathrm{s}, \mathrm{OCH}_{2} \mathrm{CH}_{2} \mathrm{O}\right), 4.01(2.7 \mathrm{H}, \mathrm{m}), 3.76(1.7 \mathrm{H}, \mathrm{m}), 3.27-3.52(12 \mathrm{H}, \mathrm{m}), 3.13$ $(3 \mathrm{H}, \mathrm{bs}), 3.04(2.0 \mathrm{H}, \mathrm{bs}), 2.61(4.5 \mathrm{H}, \mathrm{m}), 2.39(2.7 \mathrm{H}, \mathrm{m}), 2.16(4.2 \mathrm{H}, \mathrm{bs}), 2.08(4.1 \mathrm{H}, \mathrm{s}), 2.00(3.1 \mathrm{H}$, s), $1.96(4.6 \mathrm{H}, \mathrm{s}), 1.87(3.7 \mathrm{H}, \mathrm{s}) \mathrm{ppm}$. MALDI-TOF (pos) $\mathrm{m} / \mathrm{z} 40,900$.

6a: ${ }^{1} \mathrm{H}-\mathrm{NMR}\left(500 \mathrm{MHz} d_{6}\right.$-DMSO) $\delta 7.96(1 \mathrm{H}, \mathrm{bs}), 7.76(0.7 \mathrm{H}, \mathrm{bs}), 7.47$ (1.5H, bs), 5.17 (1H, s), 5.11 $(1.8 \mathrm{H}, \mathrm{m}), 4.79(1.2 \mathrm{H}, \mathrm{m}), 4.69(1.5 \mathrm{H}, \mathrm{m}), 4.62(0.9 \mathrm{H}, \mathrm{m}), 4.25(0.9 \mathrm{H}, \mathrm{m}), 4.16(1 \mathrm{H}, \mathrm{m}), 3.97(3.2 \mathrm{H}$, $\mathrm{m}), 3.74(2.9 \mathrm{H}, \mathrm{m}), 3.56(1.6 \mathrm{H}, \mathrm{bs}), 3.04-3.12(3.8 \mathrm{H}, \mathrm{m}), 2.64(2.4 \mathrm{H}, \mathrm{bs}), 2.16(3.3 \mathrm{H}, \mathrm{bs}), 2.04(3 \mathrm{H}, \mathrm{s})$, $2.02(3.4 \mathrm{H}, \mathrm{s}), 1.95(7.1 \mathrm{H}, \mathrm{s}), 1.92(4.9 \mathrm{H}, \mathrm{s}), 1.84(3.1 \mathrm{H}, \mathrm{s}) \mathrm{ppm}$. MALDI-TOF (pos) $\mathrm{m} / z$ 147,000.

6b: ${ }^{1} \mathrm{H}-\mathrm{NMR}\left(500 \mathrm{MHz} d_{6}-\mathrm{DMSO}\right) \delta 7.95(1 \mathrm{H}, \mathrm{bs}), 7.75(0.8 \mathrm{H}, \mathrm{bs}), 7.47$ (1.6H, bs), $5.21(0.3 \mathrm{H}, \mathrm{s})$, $5.17(0.8 \mathrm{H}, \mathrm{s}), 5.12(1.8 \mathrm{H}, \mathrm{m}), 4.89(0.2 \mathrm{H}, \mathrm{m}), 4.79(1.2 \mathrm{H}, \mathrm{m}), 4.69(1.6 \mathrm{H}, \mathrm{m}), 4.62(0.8 \mathrm{H}, \mathrm{m}), 4.25$ $(0.8 \mathrm{H}, \mathrm{m}), 4.16(1.2 \mathrm{H}, \mathrm{m}), 3.98(3.4 \mathrm{H}, \mathrm{m}), 3.74(2.8 \mathrm{H}, \mathrm{m}), 3.40-3.56(15 \mathrm{H}, \mathrm{m}), 3.13(2.6 \mathrm{H}, \mathrm{bs}), 3.04$ $(1.6 \mathrm{H}, \mathrm{bs}), 2.16(3.6 \mathrm{H}, \mathrm{bs}), 2.05(4.3 \mathrm{H}, \mathrm{s}), 2.03(3.5 \mathrm{H}, \mathrm{s}), 1.96(8 \mathrm{H}, \mathrm{s}), 1.92(4.8 \mathrm{H}, \mathrm{s}), 1.84(3.8 \mathrm{H}, \mathrm{s})$ ppm. MALDI-TOF (pos) $m / z$ 144,000.

6c: ${ }^{1} \mathrm{H}-\mathrm{NMR}\left(500 \mathrm{MHz} d_{6}\right.$-DMSO) $\delta 7.96$ (1H, bs), $7.75(0.8 \mathrm{H}, \mathrm{bs}), 7.47(1.4 \mathrm{H}, \mathrm{bs}), 5.21(0.4 \mathrm{H}, \mathrm{s})$, $5.17(0.6 \mathrm{H}, \mathrm{s}), 5.12(1.4 \mathrm{H}, \mathrm{m}), 4.89(0.3 \mathrm{H}, \mathrm{m}), 4.79(0.7 \mathrm{H}, \mathrm{m}), 4.69(1.2 \mathrm{H}, \mathrm{m}), 4.62(0.5 \mathrm{H}, \mathrm{m}), 4.25$ $(0.5 \mathrm{H}, \mathrm{m}), 4.17(1 \mathrm{H}, \mathrm{m}), 3.98(2.6 \mathrm{H}, \mathrm{m}), 3.74(2 \mathrm{H}, \mathrm{m}), 3.40-3.56(8 \mathrm{H}, \mathrm{m}), 3.13(2 \mathrm{H}, \mathrm{bs}), 3.04(1.6 \mathrm{H}$, bs), $2.64(3.9 \mathrm{H}, \mathrm{bs}), 2.37(2.3 \mathrm{H}, \mathrm{bs}), 2.16(2.9 \mathrm{H}, \mathrm{bs}), 2.07(1.2 \mathrm{H}, \mathrm{s}), 2.05(1.6 \mathrm{H}, \mathrm{s}), 2.03(2.3 \mathrm{H}, \mathrm{s}), 1.95$ $(6.1 \mathrm{H}, \mathrm{s}), 1.92(3.1 \mathrm{H}, \mathrm{s}), 1.87(1 \mathrm{H}, \mathrm{s}), 1.85(1.9 \mathrm{H}, \mathrm{s}) \mathrm{ppm}$. MALDI-TOF (pos) $m / z$ 140,500.

6d: ${ }^{1} \mathrm{H}-\mathrm{NMR}\left(500 \mathrm{MHz} d_{6}\right.$-DMSO) $\delta 7.96(1 \mathrm{H}, \mathrm{bs}), 7.75(0.8 \mathrm{H}, \mathrm{bs}), 7.47(1.6 \mathrm{H}, \mathrm{bs}), 5.21(0.6 \mathrm{H}, \mathrm{m})$, $5.17(0.4 \mathrm{H}, \mathrm{s}), 5.12(1.3 \mathrm{H}, \mathrm{m}), 4.89(0.5 \mathrm{H}, \mathrm{m}), 4.79(0.5 \mathrm{H}, \mathrm{m}), 4.69(1.1 \mathrm{H}, \mathrm{m}), 4.62(0.4 \mathrm{H}, \mathrm{m}), 4.25$ $(0.4 \mathrm{H}, \mathrm{m}), 4.17(1 \mathrm{H}, \mathrm{m}), 3.98(2.4 \mathrm{H}, \mathrm{m}), 3.74(1.8 \mathrm{H}, \mathrm{m}), 3.40-3.56(8.6 \mathrm{H}, \mathrm{m}), 3.13(2.4 \mathrm{H}, \mathrm{bs}), 3.04$ $(1.6 \mathrm{H}, \mathrm{bs}), 2.64(4.1 \mathrm{H}, \mathrm{bs}), 2.37(1.9 \mathrm{H}, \mathrm{bs}), 2.16(3.1 \mathrm{H}, \mathrm{bs}), 2.07(1.7 \mathrm{H}, \mathrm{s}), 2.05(1.2 \mathrm{H}, \mathrm{s}), 2.03(1.6 \mathrm{H}$, s), $1.95(6 \mathrm{H}, \mathrm{s}), 1.92(2.3 \mathrm{H}, \mathrm{s}), 1.87(1.3 \mathrm{H}, \mathrm{s}), 1.85(1.1 \mathrm{H}, \mathrm{s}) \mathrm{ppm}$. MALDI-TOF (pos) m/z 132,500.

6e: ${ }^{1} \mathrm{H}-\mathrm{NMR}\left(500 \mathrm{MHz} d_{6}\right.$-DMSO) $\delta 7.96$ (1H, bs), 7.75 (0.8H, bs), 7.47 (1.6H, bs), 5.21 (0.8H, s), $5.17(0.3 \mathrm{H}, \mathrm{s}), 5.12(1.2 \mathrm{H}, \mathrm{m}), 4.89(0.7 \mathrm{H}, \mathrm{m}), 4.79(0.3 \mathrm{H}, \mathrm{m}), 4.69(1.1 \mathrm{H}, \mathrm{m}), 4.62(0.2 \mathrm{H}, \mathrm{m}), 4.25$ $(0.2 \mathrm{H}, \mathrm{m}), 4.17(1.1 \mathrm{H}, \mathrm{m}), 3.98(2.5 \mathrm{H}, \mathrm{m}), 3.74(1.5 \mathrm{H}, \mathrm{m}), 3.40-3.56(9 \mathrm{H}, \mathrm{m}), 3.13(2.4 \mathrm{H}, \mathrm{bs}), 3.04$ (1.7H, bs), $2.64(4.8 \mathrm{H}, \mathrm{bs}), 2.37(2.9 \mathrm{H}, \mathrm{bs}), 2.16(3.2 \mathrm{H}, \mathrm{bs}), 2.07(2.3 \mathrm{H}, \mathrm{s}), 2.05(0.8 \mathrm{H}, \mathrm{s}), 2.03(1.3 \mathrm{H}$, s), $1.95(6.8 \mathrm{H}, \mathrm{s}), 1.92(1.7 \mathrm{H}, \mathrm{s}), 1.87(2.1 \mathrm{H}, \mathrm{s}), 1.85(1 \mathrm{H}, \mathrm{s}) \mathrm{ppm}$. MALDI-TOF (pos) m/z 131,500.

6f: ${ }^{1} \mathrm{H}-\mathrm{NMR}\left(500 \mathrm{MHz} d_{6}\right.$-DMSO) $\delta 7.95(1 \mathrm{H}, \mathrm{bs}$, amide NH's), $7.74(0.9 \mathrm{H}$, bs, amide NH's), 7.45 $\left(2 \mathrm{H}, \mathrm{bs}, \mathrm{CH}_{2} \mathrm{NHC}(\mathrm{S}) \mathrm{NHCH}_{2}\right), 5.21(1.2 \mathrm{H}, \mathrm{s}, \mathrm{H} 4), 5.11(1.3 \mathrm{H}, \mathrm{d}, J=10.3 \mathrm{~Hz}, \mathrm{H} 3), 4.89(1.3 \mathrm{H}, \mathrm{m}, \mathrm{H} 2)$, $4.69(1.1 \mathrm{H}, \mathrm{d}, J=8.1 \mathrm{~Hz}, \mathrm{H1}), 4.12\left(1.3 \mathrm{H}, \mathrm{d}, J=6.1 \mathrm{~Hz}, \mathrm{OCH}_{2} \mathrm{CH}_{2} \mathrm{O}\right), 4.01(2.7 \mathrm{H}, \mathrm{m}), 3.76(1.9 \mathrm{H}, \mathrm{m})$, 3.27-3.59 (11.8H, m), $3.13(3 \mathrm{H}, \mathrm{bs}), 3.04(2.2 \mathrm{H}, \mathrm{bs}), 2.61(4.5 \mathrm{H}, \mathrm{m}), 2.39(1.8 \mathrm{H}, \mathrm{m}), 2.16(3.9 \mathrm{H}, \mathrm{bs})$, $2.08(3.9 \mathrm{H}, \mathrm{s}), 2.00(8.4 \mathrm{H}, \mathrm{s}), 1.87$ (3.6H, s) ppm. MALDI-TOF (pos) $\mathrm{m} / \mathrm{z} 122,000$. 


\section{Deacetylated}

4a: ${ }^{1} \mathrm{H}-\mathrm{NMR}\left(500 \mathrm{MHz} d_{6}\right.$-DMSO) $\delta 8.02$ (bs, 1H), 7.82 (bs 0.9H), 7.54 (bs, 1.4H), 5.12 (bm, 1.8H), $4.64(\mathrm{~m}, 3.7 \mathrm{H}), 4.33(\mathrm{~m}, 2.1 \mathrm{H}), 3.87(\mathrm{~d}, J=4.8 \mathrm{~Hz}, 1.4 \mathrm{H}), 3.74(\mathrm{~m}, 1.7 \mathrm{H}), 3.47-3.62(\mathrm{~m}, 18 \mathrm{H}), 3.17$ (bs, 2.6H), $3.08(\mathrm{bs}, 1.7 \mathrm{H}), 3.03(\mathrm{~m}, 1.3 \mathrm{H}), 2.66$ (bs, 3.7H), 2.43 (bs, 1.9H), 2.20 (bs, 3.6H), 1.89 (s, $0.4 \mathrm{H}), 1.80$ (s, 0.2H) ppm. MALDI-TOF (pos) $\mathrm{m} / \mathrm{z} 15,000$.

4b: ${ }^{1} \mathrm{H}-\mathrm{NMR}\left(500 \mathrm{MHz} d_{6}\right.$-DMSO) $\delta 8.04$ (bs, 1H), 7.51 (bs 0.8H), 5.08 (bm, 0.8H), 4.53-4.70 (m, 2.6H), $4.20(\mathrm{~m}, 1.0 \mathrm{H}), 4.09(\mathrm{~s}, 0.2 \mathrm{H}), 3.83(\mathrm{bs}, 0.9 \mathrm{H}), 3.77(\mathrm{~m}, 1.0 \mathrm{H}), 3.43-3.58(\mathrm{~m}, 13 \mathrm{H}), 3.14$ (bs, 2.0H), 3.05 (bs, 0.6H), 2.62 (bs, 1.8H), 2.39 (bs, 1.9H), 2.26 (bs, 1.6H), $1.85(\mathrm{~s}, 0.1 \mathrm{H}), 1.76(\mathrm{~s}, 0.2 \mathrm{H})$ ppm MALDI-TOF (pos) $\mathrm{m} / \mathrm{z}$ 15,100.

4c: ${ }^{1} \mathrm{H}-\mathrm{NMR}$ (500 MHz d6-DMSO) $\delta 8.03$ (bs, 1H), 7.51 (bs 0.8H), 5.08 (bm, 0.6H), 4.53-4.70 (m, 2.1H), $4.20(\mathrm{~m}, 0.6 \mathrm{H}), 4.09(\mathrm{~s}, 0.3 \mathrm{H}), 3.82(\mathrm{bs}, 0.7 \mathrm{H}), 3.72(\mathrm{~m}, 0.7 \mathrm{H}), 3.43-3.58(\mathrm{~m}, 14 \mathrm{H}), 3.14(\mathrm{bs}$, 1.8H), 2.99 (bs, 0.7H), 2.73 (bs, 1.8H), 2.24 (bs, 1.8H), 1.85 (s, 0.1H), 1.76 (s, 0.3H) ppm. MALDI-TOF (pos) $m / z 14,900$.

4d: ${ }^{1} \mathrm{H}-\mathrm{NMR}\left(500 \mathrm{MHz} d_{6}\right.$-DMSO) $\delta 8.10$ (bs, 1H), 7.55 (bs 0.9H), 5.08 (bm, 0.5H), 4.53-4.70 (m, $2.2 \mathrm{H}), 4.23(\mathrm{~m}, 0.6 \mathrm{H}), 4.12(\mathrm{~s}, 0.6 \mathrm{H}), 3.85(\mathrm{bs}, 1.2 \mathrm{H}), 3.72(\mathrm{~m}, 0.7 \mathrm{H}), 3.43-3.58(\mathrm{~m}, 15 \mathrm{H}), 3.14$ (bs, $1.8 \mathrm{H}), 2.84$ (bs, 1.9H), 2.64 (bs, 1.0H), 2.32 (bs, 1.9H), $1.85(\mathrm{~s}, 0.1 \mathrm{H}), 1.76(\mathrm{~s}, 0.1 \mathrm{H}) \mathrm{ppm}$. MALDI-TOF (pos) $m / z 15,700$.

4e: ${ }^{1} \mathrm{H}-\mathrm{NMR}\left(500 \mathrm{MHz} d_{6}\right.$-DMSO) $\delta 8.08$ (bs, 1H), 7.51 (bs 0.9H), 4.33-5.30 (m, 2.5H), 4.22 (m, $0.4 \mathrm{H}), 4.12(\mathrm{~s}, 0.9 \mathrm{H}), 3.82(\mathrm{bs}, 1.5 \mathrm{H}), 3.43-3.65(\mathrm{~m}, 20 \mathrm{H}), 3.14$ (bs, $2.3 \mathrm{H}), 2.82(\mathrm{bs}, 2.2 \mathrm{H}), 2.62$ (bs, $0.8 \mathrm{H}), 2.24$ (bs, 2.0H) ppm. MALDI-TOF (pos) $m / z$ 15,800.

4f: ${ }^{1} \mathrm{H}-\mathrm{NMR}\left(500 \mathrm{MHz} d_{6}\right.$-DMSO) $\delta 7.99$ (bs, 1H), 7.80 (bs, 1H), 7.50 (bs, 2.1H), 4.96 (bs, 1.0H), $4.73(\mathrm{~m}, 1.0 \mathrm{H}), 4.61(\mathrm{bs}, 1.2 \mathrm{H}), 4.44(\mathrm{bs}, 1.2 \mathrm{H}), 4.10(\mathrm{~d}, J=5.2 \mathrm{~Hz}, 1.2 \mathrm{H}), 3.84(\mathrm{~m}, 1.5 \mathrm{H}), 3.63(\mathrm{~m}$, 2.4H), 3.38-3.60 (m, 30H), 3.17 (bs, 3.2H), 3.08 (bs, 3.2H), 2.66 (bs, 4.6H), 2.42 (bs, 2.4H), 2.20 (bs, 4.6H) ppm. MALDI-TOF (pos) $m / z$ 15,200.

5a: ${ }^{1} \mathrm{H}-\mathrm{NMR}\left(500 \mathrm{MHz} d_{6}\right.$-DMSO) $\delta 8.03$ (bs, 1H), 7.86 (bs 0.8H), 7.52 (bs, 1.7H), 5.22 (bs, 1.0H), $5.12(\mathrm{bm}, 1.1 \mathrm{H}), 4.82(\mathrm{bs} 1.1 \mathrm{H}), 4.72(\mathrm{~m}, 2.1 \mathrm{H}), 4.55(\mathrm{~m}, 1.9 \mathrm{H}), 4.22(\mathrm{~m}, 2.1 \mathrm{H}), 3.87(\mathrm{~d}, 1.4 \mathrm{H}), 3.74$ (m, 1.8H), 3.47-3.62 (m, 34H), 3.17 (bs, 2.2H), 3.03 (bs, 1.2H), 2.70 (bs, 3.1H), 2.23 (bs, 3.2H) ppm. MALDI-TOF (pos) $m / z$ 31,200.

5b: ${ }^{1} \mathrm{H}-\mathrm{NMR}\left(500 \mathrm{MHz} d_{6}-\mathrm{DMSO}\right) \delta 8.11$ (bs, 1H), 7.57 (bs 0.9H), 5.13 (bm, 0.9H), 4.53-4.70 (m, 2.3H), $4.22(\mathrm{~m}, 0.9 \mathrm{H}), 4.11(\mathrm{~s}, 0.2 \mathrm{H}), 3.86(\mathrm{bs}, 0.9 \mathrm{H}), 3.76(\mathrm{~m}, 0.8 \mathrm{H}), 3.43-3.58(\mathrm{~m}, 18 \mathrm{H}), 3.14$ (bs, $1.7 \mathrm{H}), 3.05$ (bs, $0.8 \mathrm{H}), 2.85$ (bs, 1.6H), 2.39 (bs, 1.5H) ppm. MALDI-TOF (pos) $\mathrm{m} / z$ 31,700.

5c: ${ }^{1} \mathrm{H}-\mathrm{NMR}\left(500 \mathrm{MHz} d_{6}\right.$-DMSO) $\delta 8.06$ (bs, 1H), 7.95 (bs, 0.7H), 7.54 (bs 1.3H), 5.11 (bs, 0.9H), $4.53-4.70(\mathrm{~m}, 3.2 \mathrm{H}), 4.20(\mathrm{~m}, 1.0 \mathrm{H}), 4.09(\mathrm{~s}, 0.4 \mathrm{H}), 3.82(\mathrm{bs}, 1.1 \mathrm{H}), 3.72(\mathrm{~m}, 0.9 \mathrm{H}), 3.43-3.58(\mathrm{~m}$, 29H), 3.14 (bs, 3.3H), 3.03 (bs, 0.9H), 2.77 (bs, 3.0H), 2.24 (bs, 3.1H) ppm. MALDI-TOF (pos) $\mathrm{m} / \mathrm{z} 33,000$. 
5d: ${ }^{1} \mathrm{H}-\mathrm{NMR}\left(500 \mathrm{MHz} d_{6}\right.$-DMSO) $\delta 8.06$ (bs, 1H), 7.95 (bs, 0.7H), 7.55 (bs 1.3H), 4.53-5.30 (m, $4.0 \mathrm{H}), 4.22(\mathrm{~m}, 0.8 \mathrm{H}), 4.12(\mathrm{~s}, 0.8 \mathrm{H}), 3.85(\mathrm{bs}, 1.4 \mathrm{H}), 3.72(\mathrm{~m}, 0.7 \mathrm{H}), 3.43-3.58(\mathrm{~m}, 21 \mathrm{H}), 3.14$ (bs, 3.5H), 2.84 (bs, 3.2H), 2.64 (bs, 0.8H), 2.32 (bs, 2.7H) ppm. MALDI-TOF (pos) $\mathrm{m} / z$ 34,300.

5e: ${ }^{1} \mathrm{H}-\mathrm{NMR}\left(500 \mathrm{MHz} d_{6}\right.$-DMSO) $\delta 8.02$ (bs, 1H), 7.86 (bs, 0.9H), 7.51 (bs, 1.7H), 4.33-5.30 (m, $4.0 \mathrm{H}), 4.22(\mathrm{~m}, 0.3 \mathrm{H}), 4.12(\mathrm{~s}, 1.0 \mathrm{H}), 3.85$ (bs, 1.3H), 3.43-3.65 (m, 29H), 3.18 (bs, 4,4H), 2.70 (bs, 3.8H), 2.23 (bs, 3.7H) ppm. MALDI-TOF (pos) $\mathrm{m} / z$ 34,300.

5f: ${ }^{1} \mathrm{H}-\mathrm{NMR}\left(500 \mathrm{MHz} d_{6}\right.$-DMSO) $\delta 7.97$ (bs, 1H), 7.78 (bs, 0.9H), 7.44 (bs, 2.0H), 4.97 (bs, 0.8H), $4.75(\mathrm{~m}, 0.9 \mathrm{H}), 4.65(\mathrm{bs}, 1.2 \mathrm{H}), 4.44(\mathrm{bs}, 1.2 \mathrm{H}), 4.08(\mathrm{~m}, 1.2 \mathrm{H}), 3.80(\mathrm{~m}, 1.5 \mathrm{H}), 3.38-3.65(\mathrm{~m}, 30 \mathrm{H})$, 3.13 (bs, 2.9H), 3.05 (bs, 2.3H), 2.62 (bs, 4.3H), 2.46 (bs, 2.1H), 2.17 (bs, 3.9H) ppm. MALDI-TOF (pos) $\mathrm{m} / \mathrm{z} 31,500$.

6a: ${ }^{1} \mathrm{H}-\mathrm{NMR}\left(500 \mathrm{MHz} d_{6}\right.$-DMSO) $\delta 8.02$ (bs, 1H), 7.81 (bs 0.9H), 7.53 (bs, 1.3H), 5.22 (bs, 0.8H), $5.12(\mathrm{bs}, 0.8 \mathrm{H}), 4.64(\mathrm{~m}, 3.7 \mathrm{H}), 4.22(\mathrm{~m}, 1.7 \mathrm{H}), 3.87(\mathrm{~m}, 1.2 \mathrm{H}), 3.74(\mathrm{bs}, 1.4 \mathrm{H}), 3.47-3.62(\mathrm{~m}, 28 \mathrm{H})$, 3.17 (bs, 1.8H), 3.08 (bs, 2.4H), 2.66 (bs, 2.7H), 2.43 (bs, 1.3H), 2.20 (bs, 3.0H) ppm. MALDI-TOF (pos) $m / z 100,000$.

6b: ${ }^{1} \mathrm{H}-\mathrm{NMR}\left(500 \mathrm{MHz} d_{6}\right.$-DMSO) $\delta 8.08$ (bs, 1H), 7.57 (bs 0.8H), 5.15 (bm, 0.9H), 4.53-4.79 (m, 2.3H), $4.23(\mathrm{~m}, 0.9 \mathrm{H}), 4.10(\mathrm{~s}, 0.2 \mathrm{H}), 3.83$ (bs, 0.9H), 3.77 (m, 1.0H), 3.43-3.58 (m, 16H), 3.18 (bs, 1.0H), 3.03 (bs, 0.9H), 2.77 (bs, 1.2H), 2.29 (bs, 1.0H) ppm. MALDI-TOF (pos) $\mathrm{m} / \mathrm{z} 101,000$.

6c: ${ }^{1} \mathrm{H}-\mathrm{NMR}(500 \mathrm{MHz} d 6-\mathrm{DMSO}) \delta 8.06$ (bs, 1H),7.83 (bs, 0.6H), 7.55 (bs 1.2H), $5.13(\mathrm{~m} \mathrm{1.2H})$, $4.53-4.70(\mathrm{~m}, 3.1 \mathrm{H}), 4.23(\mathrm{~m}, 1.0 \mathrm{H}), 4.12(\mathrm{~s}, 0.4 \mathrm{H}), 3.86(\mathrm{bs}, 1.4 \mathrm{H}), 3.72(\mathrm{~m}, 1.0 \mathrm{H}), 3.43-3.58(\mathrm{~m}$, 21H), 3.18 (bs, 1.8H), 3.03 (bs, 0.8H), 2.73 (bs, 2.6H), 2.25 (bs, 2.3H) ppm. MALDI-TOF (pos) $m / z 101,500$.

6d: ${ }^{1} \mathrm{H}-\mathrm{NMR}\left(500 \mathrm{MHz} d_{6}\right.$-DMSO) $\delta 8.03$ (bs, 1H), 7.89 (bs, 0.9H), 7.55 (bs, 1.5H), 5.13 (m, 0.9H), $4.53-4.70(\mathrm{~m}, 3.1 \mathrm{H}), 4.23(\mathrm{~m}, 0.8 \mathrm{H}), 4.12(\mathrm{~s}, 0.7 \mathrm{H}), 3.85(\mathrm{bs}, 1.2 \mathrm{H}), 3.72(\mathrm{~m}, 0.4 \mathrm{H}), 3.43-3.58(\mathrm{~m}$, 23H), 3.14 (bs, 4.5H), 2.70 (bs, 3.5H), 2.23 (bs, 3.5H) ppm. MALDI-TOF (pos) $\mathrm{m} / \mathrm{z} 102,000$.

6e: ${ }^{1} \mathrm{H}-\mathrm{NMR}\left(500 \mathrm{MHz} d_{6}\right.$-DMSO) $\delta 8.06$ (bs, 1H), 7.55 (bs 0.8H), 4.33-5.30 (m, 2.2H), 4.22 (m, $0.4 \mathrm{H}), 4.12(\mathrm{~s}, 0.5 \mathrm{H}), 3.82(\mathrm{bs}, 0.8 \mathrm{H}), 3.43-3.65(\mathrm{~m}, 12 \mathrm{H}), 3.14(\mathrm{bs}, 2.2 \mathrm{H}), 2.77$ (bs, 1.7H), 2.28 (bs, $1.8 \mathrm{H}) \mathrm{ppm}$. MALDI-TOF (pos) $\mathrm{m} / \mathrm{z} 106,500$.

6f: ${ }^{1} \mathrm{H}-\mathrm{NMR}\left(500 \mathrm{MHz} d_{6}\right.$-DMSO) $\delta 8.00(\mathrm{bs}, 1 \mathrm{H}), 7.80$ (bs, 0.9H), 7.48 (bs, 1.6H), 4.99 (bs, 0.7H), $4.80(\mathrm{~m}, 0.7 \mathrm{H}), 4.63(\mathrm{bs}, 0.9 \mathrm{H}), 4.48(\mathrm{bs}, 0.8 \mathrm{H}), 4.12(\mathrm{~s}, 0.8 \mathrm{H}), 3.80(\mathrm{~m}, 0.9 \mathrm{H}), 3.38-3.65(\mathrm{~m}, 14 \mathrm{H})$, 3.18 (bs, 2.4H), 3.09 (bs, 1.7H), 2.62 (bs, 3.3H), 2.46 (bs, 1.5H), 2.17 (bs, 4.0H) ppm. MALDI-TOF (pos) $m / z 101,000$.

3.5.5. Representative Procedure for the Synthesis of Acetyl Protected N-Acetylgalactose and Galactose Functionalized Dendrimers

An aqueous solution of amine terminated Starburst G(4)-PAMAM dendrimer $(2.478 \mathrm{~g}$ of a $17 \%$ $\mathrm{w} / \mathrm{w}$ solution in water, $421.2 \mathrm{mg}, 31.2 \mu \mathrm{mol})$ was lyophilized to leave a foamy residue. DMSO (7.02 mL) 
was added to this residue to give a $60 \mathrm{mg} / \mathrm{mL}$ solution. A $300 \mathrm{mM}$ solution of $3(0.35 \mathrm{~mL}, 85 \mu \mathrm{mol}$, $40.2 \mathrm{mg}$ ) in DMSO was added to the $60 \mathrm{mg} / \mathrm{mL} \mathrm{G}(4)$ PAMAM dendrimer solution $(0.5 \mathrm{~mL}, 30 \mathrm{mg}$, $4.40 \mu \mathrm{mol})$. The reaction was stirred for $8 \mathrm{~h}$ at which point a $75 \mu \mathrm{L}$ aliquot was removed for MALDI-TOF analysis. After MALDI-TOF analysis indicated reaction completion, a $300 \mathrm{mM}$ solution of $1(0.31 \mathrm{~mL}, 73 \mu \mathrm{mol}, 35 \mathrm{mg})$ was added. The solution was then stirred for $8 \mathrm{~h}$, lyophilized, and directly subjected to deacetylation conditions. The amounts of reagents used for individual compounds are listed in Table 6.

Table 6. Amounts used in synthesis of compounds $7 \mathbf{a}-7 \mathbf{f}, 8 \mathbf{a}-8 \mathbf{f}$ and $9 \mathbf{a}-9 \mathbf{f}$.

\begin{tabular}{ccccc}
\hline $\begin{array}{c}\text { Compound } \\
\text { Number }\end{array}$ & $\begin{array}{c}\text { PAMAM } \\
\text { Generation }\end{array}$ & PAMAM $(\boldsymbol{\mu m o l})$ & GalNAc $(\boldsymbol{\mu m o l})\left(\mathbf{q}^{\mathbf{a}}\right)$ & $\begin{array}{c}\text { Galactose }(\boldsymbol{\mu m o l})(\mathbf{r} \\
\mathbf{a})\end{array}$ \\
\hline $\mathbf{7 a}$ & 3 & 4.4 & 0 & 140.8 \\
$\mathbf{7 b}$ & 3 & 4.4 & 28.2 & 112.6 \\
$\mathbf{7 c}$ & 3 & 4.4 & 56.3 & 84.5 \\
$\mathbf{7 d}$ & 3 & 4.4 & 84.5 & 56.3 \\
$\mathbf{7 e}$ & 3 & 4.4 & 112.6 & 28.2 \\
$\mathbf{7 f}$ & 3 & 4.4 & 140.8 & 0 \\
$\mathbf{8 a}$ & 4 & 2.2 & 0 & 140.8 \\
$\mathbf{8 b}$ & 4 & 2.2 & 28.2 & 112.6 \\
$\mathbf{8 c}$ & 4 & 2.2 & 56.3 & 84.5 \\
$\mathbf{8 d}$ & 4 & 2.2 & 84.5 & 56.3 \\
$\mathbf{8 e}$ & 4 & 2.2 & 112.6 & 28.2 \\
$\mathbf{8 f}$ & 4.2 & 140.8 & 0 \\
$\mathbf{9 a}$ & 4 & 0.5 & 96.0 \\
$\mathbf{9 b}$ & 6 & 0.5 & 24.0 & 72.0 \\
$\mathbf{9 c}$ & 6 & 0.5 & 48.0 & 48.0 \\
$\mathbf{9 d}$ & 6 & 0.5 & 72.0 & 24.0 \\
$\mathbf{9 e}$ & 6 & 0.5 & 96.0 & 0 \\
$\mathbf{9 f}$ & 6 & 0.5 & 120.0 & \\
\hline
\end{tabular}

${ }^{\text {a }}$ Values for $\mathrm{q}$ and $\mathrm{r}$ (as shown in Scheme 2 of the primary manuscript) derive directly from the $\mu$ mol values shown here.

\subsubsection{General Deacetylation Procedure to Afford Dendrimers 7-9}

To the lyophilized solid peracetylated dendrimers, $1 \mathrm{~mL}$ of 1:1 water-methanol was added, at which point the dendrimer became a white precipitate. To this mixture was added NaOMe $(0.2$ equiv., $0.8 \mathrm{M}$ in $\mathrm{MeOH}$ ) for each peripheral carbohydrate, and it was allowed to stir for $3 \mathrm{~h}$. If, at this time, the mixture had not become a clear solution a further 0.2 equivalents of $\mathrm{NaOMe}(0.8 \mathrm{M}$ in $\mathrm{MeOH})$ was added, and this step was repeated until the mixture became a clear and colorless solution. Aqueous $\mathrm{HCl}$ solution $(0.1 \mathrm{M})$ was then added slowly until the $\mathrm{pH}$ was $\sim 7$. This neutralized solution was placed in a dialysis membrane (Mw cutoff 3,500 Da) and dialyzed in $1 \mathrm{~L}$ of DI water for $8 \mathrm{~h}$. The water was changed and let stand for a further $8 \mathrm{~h}$ twice more. The remaining liquid in the membrane was frozen and lyophilized to give a white fluffy solid. Compounds were characterized with ${ }^{1} \mathrm{H}-\mathrm{NMR}$ and MALDI-TOF MS. MALDI-TOF MS data is summarized in Table 7. 
Table 7. MALDI-TOF MS data for heterogeneously functionalized dendrimers 7a-f, 8a-f and $9 \mathbf{a}-\mathbf{f}$.

\begin{tabular}{cccc}
\hline $\begin{array}{c}\text { Compound } \\
\text { Number }\end{array}$ & $\begin{array}{c}\mathbf{M}_{\mathbf{w}} \text { after Galactose } \\
\text { Addition }\end{array}$ & $\begin{array}{c}\mathbf{M}_{\mathbf{w}} \text { after Galactosamine } \\
\text { Addition }\end{array}$ & $\mathbf{M}_{\mathbf{w}}$ after Deacylation \\
\hline $\mathbf{7 a}$ & 19100 & 8950 & 15000 \\
$\mathbf{7 b}$ & 19000 & 11700 & 15100 \\
$\mathbf{7 c}$ & 18900 & 13900 & 14900 \\
$\mathbf{7 d}$ & 19300 & 15700 & 15700 \\
$\mathbf{7 e}$ & 19000 & 18200 & 15800 \\
$\mathbf{7 f}$ & $\mathrm{n} / \mathrm{a} *$ & 20000 & 16400 \\
$\mathbf{8 a}$ & 40000 & 18200 & 31200 \\
$\mathbf{8 b}$ & 39700 & 23900 & 31700 \\
$\mathbf{8 c}$ & 40200 & 28300 & 33000 \\
$\mathbf{8 d}$ & 39700 & 33500 & 34300 \\
$\mathbf{8 e}$ & 40500 & 37200 & 34300 \\
$\mathbf{8 f}$ & $\mathrm{n} / \mathrm{a}$ & 39300 & 33300 \\
$\mathbf{9 a}$ & 119500 & 66500 & 100000 \\
$\mathbf{9 b}$ & 119000 & 77500 & 101000 \\
$\mathbf{9 c}$ & 119000 & 92000 & 101500 \\
$\mathbf{9 d}$ & 121500 & 101000 & 102000 \\
$\mathbf{9 e}$ & 121500 & 117000 & 106500 \\
$\mathbf{9 f}$ & $\mathrm{n} / \mathrm{a}$ & 125000 & 107500 \\
\hline
\end{tabular}

$* \mathrm{n} / \mathrm{a}=$ not available.

\subsubsection{Spectroscopic Data for Compounds 7-9}

Acetylated

7a: ${ }^{1} \mathrm{H}-\mathrm{NMR}\left(500 \mathrm{MHz} d_{6}\right.$-DMSO) $\delta 7.95$ (1H, bs, amide NH's), 7.74-7.79 (1.4H, m, amide NH's, $\mathrm{NH}$ 'Ac), $7.46\left(2 \mathrm{H}, \mathrm{bs}, \mathrm{CH}_{2} \mathrm{NHC}(\mathrm{S}) \mathrm{NHCH}_{2}\right), 5.21(1.2 \mathrm{H}, \mathrm{d}, J=3.2 \mathrm{~Hz}, \mathrm{H} 4), 5.17(0.2 \mathrm{H}, \mathrm{s}, \mathrm{H} 4$ '), 5.11 $(1.2 \mathrm{H}, \mathrm{dd}, J=3.2,10.3 \mathrm{~Hz}, \mathrm{H} 3), 4.92\left(0.2 \mathrm{H}, \mathrm{d}, J=10.3 \mathrm{~Hz}, \mathrm{H} 3{ }^{\prime}\right), 4.89$ (1.2H, t, $\left.J=9.7 \mathrm{~Hz}, \mathrm{H} 2\right), 4.69$ $(1.2 \mathrm{H}, \mathrm{d}, J=7.6 \mathrm{~Hz}, \mathrm{H} 1), 4.51\left(0.2 \mathrm{H}, \mathrm{d}, J=8.4 \mathrm{~Hz}, \mathrm{H} 1^{\prime}\right), 4.12(1.2 \mathrm{H}, \mathrm{m}), 4.01(3.1 \mathrm{H}, \mathrm{m}), 3.83(0.2 \mathrm{H}$, app q, $\left.J=8.4,9.0,10.3 \mathrm{~Hz}, \mathrm{H} 2^{\prime}\right), 3.76(2.0 \mathrm{H}, \mathrm{m}), 3.27-3.59(14.2 \mathrm{H}, \mathrm{m}), 3.13(3.1 \mathrm{H}, \mathrm{bs}), 3.04(2.4 \mathrm{H}$, bs), $2.61(3.1 \mathrm{H}, \mathrm{m}), 2.16(4.7 \mathrm{H}, \mathrm{bs}), 2.08(4 \mathrm{H}, \mathrm{s}), 2.00(2.8 \mathrm{H}, \mathrm{s}), 1.96(4.6 \mathrm{H}, \mathrm{s}), 1.87(3 \mathrm{H}, \mathrm{s}) 1.72(0.8 \mathrm{H}$, s) ppm. MALDI-TOF (pos) $m / z$ 19,100.

7b: ${ }^{1} \mathrm{H}-\mathrm{NMR}\left(500 \mathrm{MHz} d_{6}\right.$-DMSO) $\delta 7.95$ (1H, bs, amide NH's), $7.79(0.7 \mathrm{H}, \mathrm{d}, J=9.0 \mathrm{~Hz}, \mathrm{NH}$ 'Ac), $7.74\left(0.9 \mathrm{H}, \mathrm{bs}\right.$, amide NH's), $7.46\left(2.1 \mathrm{H}, \mathrm{bs}, \mathrm{CH}_{2} \mathrm{NHC}(\mathrm{S}) \mathrm{NHCH}_{2}\right), 5.21(1.1 \mathrm{H}, \mathrm{d}, J=3.2 \mathrm{~Hz}, \mathrm{H} 4), 5.17$ $\left.\left(0.4 \mathrm{H}, \mathrm{s}, \mathrm{H} 4{ }^{\prime}\right), 5.11(1.1 \mathrm{H}, \mathrm{dd}, J=3.2,10.3 \mathrm{~Hz}, \mathrm{H} 3), 4.92(0.4 \mathrm{H}, \mathrm{d}, J=10.3 \mathrm{~Hz}, \mathrm{H} 3)^{\prime}\right), 4.89(1.1 \mathrm{H}, \mathrm{t}, J=$ $9.7 \mathrm{~Hz}, \mathrm{H} 2), 4.69(1.1 \mathrm{H}, \mathrm{d}, J=7.6 \mathrm{~Hz}, \mathrm{H} 1), 4.51\left(0.4 \mathrm{H}, \mathrm{d}, J=8.4 \mathrm{~Hz}, \mathrm{H} 1^{\prime}\right), 4.12(1.1 \mathrm{H}, \mathrm{m}), 4.01$ $(3.7 \mathrm{H}, \mathrm{m}), 3.83(0.4 \mathrm{H}$, app q, $J=8.4,9.0,10.3 \mathrm{~Hz}, \mathrm{H} 2$ '), $3.76(2.3 \mathrm{H}, \mathrm{m}), 3.27-3.59(15.9 \mathrm{H}, \mathrm{m}), 3.13$ $(3.1 \mathrm{H}, \mathrm{bs}), 3.04(2.6 \mathrm{H}, \mathrm{bs}), 2.61(5.4 \mathrm{H}, \mathrm{m}), 2.39(3 \mathrm{H}, \mathrm{m}), 2.16(4.9 \mathrm{H}, \mathrm{bs}), 2.08(3 \mathrm{H}, \mathrm{s}), 2.06(1.5 \mathrm{H}, \mathrm{s})$, $1.96(4.9 \mathrm{H}, \mathrm{s}), 1.87(2.9 \mathrm{H}, \mathrm{s}), 1.85(1.4 \mathrm{H}, \mathrm{s}), 1.74(1.2 \mathrm{H}, \mathrm{s}) \mathrm{ppm}$. MALDI-TOF (pos) $\mathrm{m} / z$ 19,000.

7c: ${ }^{1} \mathrm{H}-\mathrm{NMR}\left(500 \mathrm{MHz} d_{6}\right.$-DMSO) $\delta 7.95$ (1H, bs, amide NH's), $7.79(0.8 \mathrm{H}, \mathrm{d}, J=9.0 \mathrm{~Hz}, \mathrm{NH}$ 'Ac), $7.74\left(1 \mathrm{H}, \mathrm{bs}\right.$, amide NH's), $7.46\left(2 \mathrm{H}, \mathrm{bs}, \mathrm{CH}_{2} \mathrm{NHC}(\mathrm{S}) \mathrm{NHCH}_{2}\right), 5.21(0.8 \mathrm{H}, \mathrm{d}, J=3.2 \mathrm{~Hz}, \mathrm{H} 4), 5.17$ 
(0.7H, s, H4'), $5.11(0.8 \mathrm{H}, \mathrm{dd}, J=3.2,10.3 \mathrm{~Hz}, \mathrm{H} 3), 4.92\left(0.7 \mathrm{H}, \mathrm{d}, J=10.3 \mathrm{~Hz}, \mathrm{H} 3{ }^{\prime}\right), 4.89(1.3 \mathrm{H}, \mathrm{t}$, $J=9.7 \mathrm{~Hz}, \mathrm{H} 2), 4.69(1.3 \mathrm{H}, \mathrm{d}, J=7.6 \mathrm{~Hz}, \mathrm{H} 1), 4.51\left(0.7 \mathrm{H}, \mathrm{d}, J=8.4 \mathrm{~Hz}, \mathrm{H} 1{ }^{\prime}\right), 4.12(0.8 \mathrm{H}, \mathrm{m}), 4.01$ $(3.8 \mathrm{H}, \mathrm{m}), 3.83(0.7 \mathrm{H}$, app q, $J=8.4,9.0,10.3 \mathrm{~Hz}, \mathrm{H} 2$ '), $3.76(1.9 \mathrm{H}, \mathrm{m}), 3.27-3.59(15.6 \mathrm{H}, \mathrm{m}), 3.13$ $(3.2 \mathrm{H}, \mathrm{bs}), 3.04(2.6 \mathrm{H}, \mathrm{bs}), 2.61(5.6 \mathrm{H}, \mathrm{m}), 2.39(3 \mathrm{H}, \mathrm{m}), 2.16(4.7 \mathrm{H}, \mathrm{bs}), 2.08(4 \mathrm{H}, \mathrm{s}), 2.00(4 \mathrm{H}, \mathrm{s})$, $1.96(4 \mathrm{H}, \mathrm{s}), 1.87$ (4H, s) ppm. MALDI-TOF (pos) $m / z$ 18,900.

7d: ${ }^{1} \mathrm{H}-\mathrm{NMR}(500 \mathrm{MHz} d 6-\mathrm{DMSO}) \delta 7.95(1 \mathrm{H}, \mathrm{bs}$, amide NH's), $7.79(1.1 \mathrm{H}, \mathrm{d}, J=9.0 \mathrm{~Hz}, \mathrm{NH}$ 'Ac), $7.74\left(0.9 \mathrm{H}, \mathrm{bs}\right.$, amide NH's), $7.46\left(2.1 \mathrm{H}, \mathrm{bs}, \mathrm{CH}_{2} \mathrm{NHC}(\mathrm{S}) \mathrm{NHCH}_{2}\right), 5.21(0.6 \mathrm{H}, \mathrm{d}, J=3.2 \mathrm{~Hz}, \mathrm{H} 4), 5.17$ $\left.\left(0.9 \mathrm{H}, \mathrm{s}, \mathrm{H} 4{ }^{\prime}\right), 5.11(0.6 \mathrm{H}, \mathrm{dd}, J=3.2,10.3 \mathrm{~Hz}, \mathrm{H} 3), 4.92(0.9 \mathrm{H}, \mathrm{d}, J=10.3 \mathrm{~Hz}, \mathrm{H} 3)^{\prime}\right), 4.89(0.6 \mathrm{H}, \mathrm{t}$, $J=9.7 \mathrm{~Hz}, \mathrm{H} 2), 4.69(0.6 \mathrm{H}, \mathrm{d}, J=7.6 \mathrm{~Hz}, \mathrm{H} 1), 4.51\left(0.9 \mathrm{H}, \mathrm{d}, J=8.4 \mathrm{~Hz}, \mathrm{H} 1{ }^{\prime}\right), 4.12(0.6 \mathrm{H}, \mathrm{m}), 4.01$ $(4.2 \mathrm{H}, \mathrm{m}), 3.83(0.9 \mathrm{H}$, app q, $J=8.4,9.0,10.3 \mathrm{~Hz}, \mathrm{H} 2$ '), $3.76(2.1 \mathrm{H}, \mathrm{m}), 3.27-3.59(15.7 \mathrm{H}, \mathrm{m}), 3.13$ $(3.1 \mathrm{H}, \mathrm{bs}), 3.04(2.4 \mathrm{H}, \mathrm{bs}), 2.61(5.2 \mathrm{H}, \mathrm{m}), 2.39(3.1 \mathrm{H}, \mathrm{m}), 2.16(4.8 \mathrm{H}, \mathrm{bs}), 2.07(1.9 \mathrm{H}, \mathrm{s}), 2.06(2.8 \mathrm{H}$, s), $1.98(0.7 \mathrm{H}, \mathrm{s}), 1.96(4.9 \mathrm{H}, \mathrm{s}), 1.87(1.9 \mathrm{H}, \mathrm{s}), 1.85(2.5 \mathrm{H}, \mathrm{s}), 1.74(2.5 \mathrm{H}, \mathrm{s}) \mathrm{ppm}$. MALDI-TOF (pos) $\mathrm{m} / \mathrm{z} 19,300$.

7e: ${ }^{1} \mathrm{H}-\mathrm{NMR}\left(500 \mathrm{MHz} d_{6}\right.$-DMSO) $\delta 7.95$ (1H, bs, amide NH's), $7.79(1.3 \mathrm{H}, \mathrm{d}, J=9.0 \mathrm{~Hz}, \mathrm{NH}$ 'Ac), $7.74\left(0.8 \mathrm{H}, \mathrm{bs}\right.$, amide NH's), $7.46\left(2.1 \mathrm{H}, \mathrm{bs}, \mathrm{CH}_{2} \mathrm{NHC}(\mathrm{S}) \mathrm{NHCH}_{2}\right), 5.21(0.3 \mathrm{H}, \mathrm{d}, J=3.2 \mathrm{~Hz}, \mathrm{H} 4), 5.17$ $\left(1.1 \mathrm{H}, \mathrm{s}, \mathrm{H} 4{ }^{\prime}\right), 5.11(0.3 \mathrm{H}, \mathrm{dd}, J=3.2,10.3 \mathrm{~Hz}, \mathrm{H} 3), 4.92\left(1.1 \mathrm{H}, \mathrm{d}, J=10.3 \mathrm{~Hz}, \mathrm{H} 3{ }^{\prime}\right), 4.89(0.3 \mathrm{H}, \mathrm{t}, J=$ $9.7 \mathrm{~Hz}, \mathrm{H} 2), 4.69(0.3 \mathrm{H}, \mathrm{d}, J=7.6 \mathrm{~Hz}, \mathrm{H} 1), 4.51\left(1.1 \mathrm{H}, \mathrm{d}, J=8.4 \mathrm{~Hz}, \mathrm{H} 1{ }^{\prime}\right), 4.12(0.8 \mathrm{H}, \mathrm{m}), 4.01$ $(3.8 \mathrm{H}, \mathrm{m}), 3.83\left(1.1 \mathrm{H}\right.$, app q, $\left.J=8.4,9.0,10.3 \mathrm{~Hz}, \mathrm{H} 2{ }^{\prime}\right), 3.76(0.3 \mathrm{H}, \mathrm{m}), 3.27-3.59(15.3 \mathrm{H}, \mathrm{m}), 3.13$ $(2.8 \mathrm{H}, \mathrm{bs}), 3.04(2.2 \mathrm{H}, \mathrm{bs}), 2.61(4.7 \mathrm{H}, \mathrm{m}), 2.39(2.7 \mathrm{H}, \mathrm{m}), 2.16(4.3 \mathrm{H}, \mathrm{bs}), 2.07(1.4 \mathrm{H}, \mathrm{s}), 2.06(3.4 \mathrm{H}$, s), $1.95(5 \mathrm{H}, \mathrm{s}), 1.87(1 \mathrm{H}, \mathrm{s}), 1.85(3.5 \mathrm{H}, \mathrm{s}), 1.74(3.3 \mathrm{H}, \mathrm{s}) \mathrm{ppm}$. MALDI-TOF (pos) $\mathrm{m} / \mathrm{z}$ 19,000.

7f: ${ }^{1} \mathrm{H}-\mathrm{NMR}\left(500 \mathrm{MHz} d_{6}\right.$-DMSO) $\delta 7.96(1 \mathrm{H}$, bs, amide $\mathrm{NH}$ 's), $7.79(1.3 \mathrm{H}, \mathrm{d}, J=9.0 \mathrm{~Hz}, \mathrm{NH}$ 'Ac), $7.74\left(1.1 \mathrm{H}, \mathrm{bs}\right.$, amide NH's), $7.46\left(2.2 \mathrm{H}, \mathrm{m}, \mathrm{CH}_{2} \mathrm{NHC}(\mathrm{S}) \mathrm{NHCH}_{2}\right), 5.17(1.3 \mathrm{H}, \mathrm{s}, \mathrm{H} 4$ '), 4.92 (1.3H, dd, $\left.J=3.0,10.3 \mathrm{~Hz}, \mathrm{H}^{\prime}\right), 4.51\left(1.3 \mathrm{H}, \mathrm{d}, J=8.4 \mathrm{~Hz}, \mathrm{H} 1^{\prime}\right), 4.01(4.7 \mathrm{H}, \mathrm{m}), 3.83(1.3 \mathrm{H}$, app q, $J=8.4,9.0$, $10.3 \mathrm{~Hz}, \mathrm{H} 2$ '), 3.27-3.59 (16.5H, m), $3.13(3.2 \mathrm{H}, \mathrm{bs}), 3.04(2.3 \mathrm{H}, \mathrm{bs}), 2.61(5.1 \mathrm{H}, \mathrm{m}), 2.39(2.5 \mathrm{H}, \mathrm{m})$, $2.16(4.1 \mathrm{H}, \mathrm{bs}), 2.06(4.7 \mathrm{H}, \mathrm{s}), 1.95(4.7 \mathrm{H}, \mathrm{s}), 1.85(4.2 \mathrm{H}, \mathrm{s}), 1.74(4.2 \mathrm{H}, \mathrm{s}) \mathrm{ppm}$. MALDI-TOF (pos) $m / z 19,900$.

8a: ${ }^{1} \mathrm{H}-\mathrm{NMR}\left(500 \mathrm{MHz} d_{6}\right.$-DMSO) $\delta 7.95$ (1H, bs, amide NH's), 7.74-7.79 (1.4H, m, amide NH's, $\mathrm{NH}$ 'Ac), $7.45\left(2.1 \mathrm{H}, \mathrm{bs}, \mathrm{CH}_{2} \mathrm{NHC}(\mathrm{S}) \mathrm{NHCH}_{2}\right), 5.21(1.3 \mathrm{H}, \mathrm{s}, \mathrm{H} 4), 5.17(0.2 \mathrm{H}, \mathrm{s}, \mathrm{H} 4), 5.12(1.3 \mathrm{H}, \mathrm{d}$, $10.5 \mathrm{~Hz}, \mathrm{H} 3), 4.92(0.2 \mathrm{H}, \mathrm{m}, \mathrm{H} 3$ '), 4.89 (1.3H, t, $J=9.7 \mathrm{~Hz}, \mathrm{H} 2), 4.69$ (1.2H, d, J=7.6 Hz, H1), 4.51 $\left(0.2 \mathrm{H}, \mathrm{d}, J=8.4 \mathrm{~Hz}, \mathrm{H} 1^{\prime}\right), 4.12(1.3 \mathrm{H}, \mathrm{m}), 4.00(3.3 \mathrm{H}, \mathrm{m}), 3.83(0.2 \mathrm{H}$, app q, $J=8.4,9.0,10.3 \mathrm{~Hz}$, H2'), $3.76(2.2 \mathrm{H}, \mathrm{m}), 3.27-3.59(12.7 \mathrm{H}, \mathrm{m}), 3.13(2.8 \mathrm{H}, \mathrm{bs}), 3.04(2.4 \mathrm{H}, \mathrm{bs}), 2.61(5.1 \mathrm{H}, \mathrm{m}), 2.16$ $(4.8 \mathrm{H}, \mathrm{bs}), 2.08(4.7 \mathrm{H}, \mathrm{s}), 2.00(2.5 \mathrm{H}, \mathrm{s}), 1.96(5.3 \mathrm{H}, \mathrm{s}), 1.87(3.3 \mathrm{H}, \mathrm{s}) 1.72(0.8 \mathrm{H}, \mathrm{s}) \mathrm{ppm}$. MALDI-TOF (pos) $\mathrm{m} / \mathrm{z} 40,000$.

8b: ${ }^{1} \mathrm{H}-\mathrm{NMR}\left(500 \mathrm{MHz} d_{6}\right.$-DMSO) $\delta 7.95$ (1H, bs, amide NH's), $7.79(0.7 \mathrm{H}, \mathrm{d}, J=9.0 \mathrm{~Hz}, \mathrm{NH}$ 'Ac), $7.74\left(1.0 \mathrm{H}, \mathrm{bs}\right.$, amide NH's), $7.46\left(2.1 \mathrm{H}, \mathrm{m}, \mathrm{CH}_{2} \mathrm{NHC}(\mathrm{S}) \mathrm{NHCH}_{2}\right), 5.21(1.2 \mathrm{H}, \mathrm{s}, \mathrm{H} 4), 5.17(0.5 \mathrm{H}, \mathrm{s}$, H4'), $5.11(1.3 \mathrm{H}, \mathrm{m}, \mathrm{H} 3), 4.92\left(0.5 \mathrm{H}, \mathrm{d}, J=10.3 \mathrm{~Hz}, \mathrm{H} 3{ }^{\prime}\right), 4.89(1.3 \mathrm{H}, \mathrm{t}, J=9.7 \mathrm{~Hz}, \mathrm{H} 2), 4.69(1.1 \mathrm{H}$, $\mathrm{d}, J=7.6 \mathrm{~Hz}, \mathrm{H1}), 4.51(0.4 \mathrm{H}, \mathrm{d}, J=8.4 \mathrm{~Hz}, \mathrm{H1}), 4.12(1.3 \mathrm{H}, \mathrm{m}), 4.01(4.1 \mathrm{H}, \mathrm{m}), 3.83(0.6 \mathrm{H}$, app q, $\left.J=8.4,9.0,10.3 \mathrm{~Hz}, \mathrm{H} 2^{\prime}\right), 3.76(2.9 \mathrm{H}, \mathrm{m}), 3.27-3.59(13.8 \mathrm{H}, \mathrm{m}), 3.13(3.0 \mathrm{H}, \mathrm{bs}), 3.04$ (2.6H, bs), 2.61 
(4.4H, m), $2.39(2.7 \mathrm{H}, \mathrm{m}), 2.16(4.4 \mathrm{H}, \mathrm{bs}), 2.08(3.6 \mathrm{H}, \mathrm{s}), 2.06(1.6 \mathrm{H}, \mathrm{s}), 1.96(5.9 \mathrm{H}, \mathrm{s}), 1.87(3.2 \mathrm{H}, \mathrm{s})$, $1.85(1.5 \mathrm{H}, \mathrm{s}), 1.74(1.3 \mathrm{H}, \mathrm{s}) \mathrm{ppm}$. MALDI-TOF (pos) $\mathrm{m} / z$ 39,700.

8c: ${ }^{1} \mathrm{H}-\mathrm{NMR}\left(500 \mathrm{MHz} d_{6}\right.$-DMSO) $\delta 7.95(1 \mathrm{H}, \mathrm{bs}$, amide NH's), $7.79(0.9 \mathrm{H}, \mathrm{d}, J=9.0 \mathrm{~Hz}, \mathrm{NH}$ 'Ac), $7.74\left(0.9 \mathrm{H}, \mathrm{bs}\right.$, amide NH's), $7.46\left(2.1 \mathrm{H}, \mathrm{bs}, \mathrm{CH}_{2} \mathrm{NHC}(\mathrm{S}) \mathrm{NHCH}_{2}\right), 5.21(0.7 \mathrm{H}, \mathrm{d}, J=3.2 \mathrm{~Hz}, \mathrm{H} 4), 5.17$ $\left(0.7 \mathrm{H}, \mathrm{s}, \mathrm{H} 4^{\prime}\right), 5.11(0.7 \mathrm{H}, \mathrm{d}, J=10.3 \mathrm{~Hz}, \mathrm{H} 3), 4.92\left(0.7 \mathrm{H}, \mathrm{d}, J=10.3 \mathrm{~Hz}, \mathrm{H} 3{ }^{\prime}\right), 4.89$ (0.7H, t, $J=9.7 \mathrm{~Hz}$, H2), $4.69(0.6 \mathrm{H}, \mathrm{d}, J=7.6 \mathrm{~Hz}, \mathrm{H} 1), 4.51(0.7 \mathrm{H}, \mathrm{d}, J=8.4 \mathrm{~Hz}, \mathrm{H} 1$ '), $4.12(0.8 \mathrm{H}, \mathrm{m}), 4.01(3.9 \mathrm{H}, \mathrm{m})$, $3.83\left(0.7 \mathrm{H}\right.$, app q, $\left.J=8.4,9.0,10.3 \mathrm{~Hz}, \mathrm{H} 2^{\prime}\right), 3.76(1.9 \mathrm{H}, \mathrm{m}), 3.27-3.59$ (13.6H, m), 3.13 (2.9H, bs), $3.04(2.4 \mathrm{H}, \mathrm{bs}), 2.61(5.3 \mathrm{H}, \mathrm{m}), 2.39(2.6 \mathrm{H}, \mathrm{m}), 2.16(4.6 \mathrm{H}, \mathrm{bs}), 2.08(5 \mathrm{H}, \mathrm{s}), 2.00(4.8 \mathrm{H}, \mathrm{s}), 1.96$ $(1.9 \mathrm{H}, \mathrm{s}), 1.87(2.4 \mathrm{H}, \mathrm{s}) 1.74(2.1 \mathrm{H}, \mathrm{s}) \mathrm{ppm}$. MALDI-TOF (pos) $m / z$ 40,200.

8d: ${ }^{1} \mathrm{H}-\mathrm{NMR}\left(500 \mathrm{MHz} d_{6}\right.$-DMSO) $\delta 7.95$ (1H, bs, amide NH's), $7.80(1.0 \mathrm{H}, \mathrm{d}, J=9.0 \mathrm{~Hz}, \mathrm{NH}$ 'Ac), $7.79\left(0.8 \mathrm{H}, \mathrm{bs}\right.$, amide NH's), $7.46\left(2.0 \mathrm{H}, \mathrm{m}, \mathrm{CH}_{2} \mathrm{NHC}(\mathrm{S}) \mathrm{NHCH}_{2}\right), 5.21(0.5 \mathrm{H}, \mathrm{s}, \mathrm{H} 4), 5.17(0.9 \mathrm{H}, \mathrm{s}$, H4'), $5.11(0.4 \mathrm{H}, \mathrm{d}, 10.3 \mathrm{~Hz}, \mathrm{H} 3), 4.92\left(1 \mathrm{H}, \mathrm{d}, J=10.3 \mathrm{~Hz}, \mathrm{H} 3{ }^{\prime}\right), 4.89$ (0.4H, t, $\left.J=9.7 \mathrm{~Hz}, \mathrm{H} 2\right), 4.69$ $(0.4 \mathrm{H}, \mathrm{d}, J=7.6 \mathrm{~Hz}, \mathrm{H} 1), 4.51\left(0.9 \mathrm{H}, \mathrm{d}, J=8.4 \mathrm{~Hz}, \mathrm{H} 1^{\prime}\right), 4.12(0.5 \mathrm{H}, \mathrm{m}), 4.01(4.1 \mathrm{H}, \mathrm{m}), 3.83(1.1 \mathrm{H}$, app q, $\left.J=8.4,9.0,10.3 \mathrm{~Hz}, \mathrm{H} 2^{\prime}\right), 3.76(2.0 \mathrm{H}, \mathrm{m}), 3.27-3.59(13.1 \mathrm{H}, \mathrm{m}), 3.13(2.7 \mathrm{H}, \mathrm{bs}), 3.04(2.0 \mathrm{H}$, bs), $2.61(4.2 \mathrm{H}, \mathrm{m}), 2.39(2.6 \mathrm{H}, \mathrm{m}), 2.16(3.8 \mathrm{H}, \mathrm{bs}), 2.07(1.7 \mathrm{H}, \mathrm{s}), 2.06(3.9 \mathrm{H}, \mathrm{s}), 1.98(1 \mathrm{H}, \mathrm{s}), 1.96$ $(5.3 \mathrm{H}, \mathrm{s}), 1.87(1.4 \mathrm{H}, \mathrm{s}), 1.85(2.9 \mathrm{H}, \mathrm{s}), 1.74(2.8 \mathrm{H}, \mathrm{s}) \mathrm{ppm}$. MALDI-TOF (pos) $\mathrm{m} / \mathrm{z} 39,700$.

8e: ${ }^{1} \mathrm{H}-\mathrm{NMR}\left(500 \mathrm{MHz} d_{6}\right.$-DMSO) $\delta 7.95(1 \mathrm{H}, \mathrm{bs}$, amide NH's), $7.79(1.3 \mathrm{H}, \mathrm{d}, J=9.0 \mathrm{~Hz}, \mathrm{NH}$ 'Ac), $7.74\left(0.8 \mathrm{H}, \mathrm{bs}\right.$, amide NH's), $7.46\left(2.1 \mathrm{H}, \mathrm{m}, \mathrm{CH}_{2} \mathrm{NHC}(\mathrm{S}) \mathrm{NHCH}_{2}\right), 5.21(0.3 \mathrm{H}, \mathrm{d}, J=3.2 \mathrm{~Hz}, \mathrm{H} 4), 5.17$ $\left(1.2 \mathrm{H}, \mathrm{s}, \mathrm{H} 4^{\prime}\right), 5.11(0.3 \mathrm{H}, \mathrm{d}, J=10.3 \mathrm{~Hz}, \mathrm{H} 3), 4.92\left(1.2 \mathrm{H}, \mathrm{d}, J=10.3 \mathrm{~Hz}, \mathrm{H} 33^{\prime}\right), 4.89(0.3 \mathrm{H}, \mathrm{t}, J=9.7 \mathrm{~Hz}$, H2), $4.69(0.2 \mathrm{H}, \mathrm{d}, J=7.6 \mathrm{~Hz}, \mathrm{H} 1), 4.51(1.2 \mathrm{H}, \mathrm{d}, J=8.4 \mathrm{~Hz}, \mathrm{H} 1$ '), $4.12(0.3 \mathrm{H}, \mathrm{m}), 4.01(3.6 \mathrm{H}, \mathrm{m})$, $3.83\left(1.3 \mathrm{H}\right.$, app q, $\left.J=8.4,9.0,10.3 \mathrm{~Hz}, \mathrm{H} 2{ }^{\prime}\right), 3.76(2.2 \mathrm{H}, \mathrm{m}), 3.27-3.59(8.3 \mathrm{H}, \mathrm{m}), 3.13(3.0 \mathrm{H}, \mathrm{bs})$, $3.04(2.1 \mathrm{H}, \mathrm{bs}), 2.61(5.0 \mathrm{H}, \mathrm{m}), 2.39(2.7 \mathrm{H}, \mathrm{m}), 2.16(4.4 \mathrm{H}, \mathrm{bs}), 2.07(1.1 \mathrm{H}, \mathrm{s}), 2.06(3.4 \mathrm{H}, \mathrm{s}), 1.95$ $(5.3 \mathrm{H}, \mathrm{s}), 1.87(1 \mathrm{H}, \mathrm{s}), 1.85(3.9 \mathrm{H}, \mathrm{s}), 1.74(3.7 \mathrm{H}, \mathrm{s}) \mathrm{ppm}$. MALDI-TOF (pos) $m / z$ 40,500.

8f: ${ }^{1} \mathrm{H}-\mathrm{NMR}\left(500 \mathrm{MHz} d_{6}\right.$-DMSO) $\delta 7.96\left(1 \mathrm{H}, \mathrm{bs}\right.$, amide NH's), $7.81\left(1.2 \mathrm{H}, \mathrm{d}, J=9.0 \mathrm{~Hz}, \mathrm{~N} H{ }^{\prime} \mathrm{Ac}\right)$, $7.74\left(0.8 \mathrm{H}, \mathrm{bs}\right.$, amide NH's), $7.46\left(2.0 \mathrm{H}, \mathrm{m}, \mathrm{CH}_{2} \mathrm{NHC}(\mathrm{S}) \mathrm{NHCH}_{2}\right), 5.17(1.3 \mathrm{H}, \mathrm{s}, \mathrm{H} 4$ '), 4.92 (1.3H, d, $\left.J=10.3 \mathrm{~Hz}, \mathrm{H} 3^{\prime}\right), 4.51\left(1.4 \mathrm{H}, \mathrm{d}, J=8.4 \mathrm{~Hz}, \mathrm{H} 1^{\prime}\right), 4.01(4.9 \mathrm{H}, \mathrm{m}), 3.83$ (1.6H, app q, $J=8.4,9.0,10.3$ Hz, H2'), 3.27-3.59 (17H, m), 3.13 (2.8H, bs), $3.04(2.1 \mathrm{H}, \mathrm{bs}), 2.61(4 \mathrm{H}, \mathrm{m}), 2.39(2 \mathrm{H}, \mathrm{m}), 2.16(3.9 \mathrm{H}$, bs), $2.06(4.7 \mathrm{H}, \mathrm{s}), 1.95(5 \mathrm{H}, \mathrm{s}), 1.85(4.5 \mathrm{H}, \mathrm{s}), 1.74(4.4 \mathrm{H}, \mathrm{s}) \mathrm{ppm}$. MALDI-TOF (pos) $\mathrm{m} / \mathrm{z} 39,300$.

9a: ${ }^{1} \mathrm{H}-\mathrm{NMR}\left(500 \mathrm{MHz} d_{6}\right.$-DMSO) $\delta 7.95(1 \mathrm{H}, \mathrm{bs}$, amide NH's), 7.74-7.79 (1.3H, m, amide NH's, $\mathrm{NH}$ Ac), $7.45\left(1.9 \mathrm{H}, \mathrm{bs}, \mathrm{CH}_{2} \mathrm{NHC}(\mathrm{S}) \mathrm{NHCH}\right), 5.21(1 \mathrm{H}, \mathrm{s}, \mathrm{H} 4), 5.17\left(0.2 \mathrm{H}, \mathrm{s}, \mathrm{H} 4^{\prime}\right), 5.11(1 \mathrm{H}, \mathrm{d}, 10.3 \mathrm{~Hz}$, H3), 4.89 (1H, t, $J=9.7 \mathrm{~Hz}, \mathrm{H} 2), 4.69(1 \mathrm{H}, \mathrm{d}, J=7.6 \mathrm{~Hz}, \mathrm{H} 1), 4.51\left(0.2 \mathrm{H}, \mathrm{d}, J=8.4 \mathrm{~Hz}, \mathrm{H} 1{ }^{\prime}\right), 4.12$ $(1 \mathrm{H}, \mathrm{m}), 4.01(2.6 \mathrm{H}, \mathrm{m}), 3.83\left(0.2 \mathrm{H}\right.$, app q, $\left.J=8.4,9.0,10.3 \mathrm{~Hz}, \mathrm{H} 2{ }^{\prime}\right), 3.76(1.5 \mathrm{H}, \mathrm{m}), 3.27-3.59$ $(11.4 \mathrm{H}, \mathrm{m}), 3.13(2.9 \mathrm{H}, \mathrm{bs}), 3.04(2.3 \mathrm{H}, \mathrm{bs}), 2.61(4.8 \mathrm{H}, \mathrm{m}), 2.16(4.1 \mathrm{H}, \mathrm{bs}), 2.08(4.2 \mathrm{H}, \mathrm{s}), 1.98$ $(7.6 \mathrm{H}, \mathrm{s}), 1.87(3.7 \mathrm{H}, \mathrm{s}) 1.72(0.8 \mathrm{H}, \mathrm{s}) \mathrm{ppm}$. MALDI-TOF (pos) $\mathrm{m} / z$ 119,500.

9b: ${ }^{1} \mathrm{H}-\mathrm{NMR}(500 \mathrm{MHz} d 6-\mathrm{DMSO}) \delta 7.96$ (1H, bs, amide NH's), $7.79(0.6 \mathrm{H}, \mathrm{d}, J=9.0 \mathrm{~Hz}, \mathrm{NH}$ 'Ac), $7.74\left(0.9 \mathrm{H}, \mathrm{bs}\right.$, amide NH's), $7.46\left(1.9 \mathrm{H}, \mathrm{bs}, \mathrm{CH}_{2} \mathrm{NHC}(\mathrm{S}) \mathrm{NHCH}_{2}\right), 5.21(2.1 \mathrm{H}, \mathrm{d}, J=3.3 \mathrm{~Hz}, \mathrm{H} 4), 5.17$ (0.4H, s, H4'), $5.11(2.1 \mathrm{H}, \mathrm{dd}, J=3.2,10.3 \mathrm{~Hz}, \mathrm{H} 3), 4.92\left(0.3 \mathrm{H}, \mathrm{d}, J=10.3 \mathrm{~Hz}, \mathrm{H} 3{ }^{\prime}\right), 4.89$ (2.1H, t, 
$J=9.7 \mathrm{~Hz}, \mathrm{H} 2), 4.69(1.9 \mathrm{H}, \mathrm{d}, J=7.6 \mathrm{~Hz}, \mathrm{H} 1), 4.51\left(0.2 \mathrm{H}, \mathrm{d}, J=8.4 \mathrm{~Hz}, \mathrm{H} 1{ }^{\prime}\right), 4.12(2.1 \mathrm{H}, \mathrm{m}), 4.01$ $(5.4 \mathrm{H}, \mathrm{m}), 3.83(0.3 \mathrm{H}$, app q, $J=8.4,9.0,10.3 \mathrm{~Hz}, \mathrm{H} 2$ '), $3.76(5.4 \mathrm{H}, \mathrm{m}), 3.27-3.59(17.5 \mathrm{H}, \mathrm{m}), 3.13$ (3.2H, bs), $3.04(2.3 \mathrm{H}, \mathrm{bs}), 2.61(4.8 \mathrm{H}, \mathrm{m}), 2.39(2.8 \mathrm{H}, \mathrm{m}), 2.16(4.4 \mathrm{H}, \mathrm{bs}), 2.08(7.8 \mathrm{H}, \mathrm{s}), 2.06(4.6 \mathrm{H}$, s), $1.96(5.5 \mathrm{H}, \mathrm{s}), 1.85(1.6 \mathrm{H}, \mathrm{s}), 1.74(1.4 \mathrm{H}, \mathrm{s}) \mathrm{ppm}$. MALDI-TOF (pos) $\mathrm{m} / \mathrm{z} 119,000$.

9c: ${ }^{1} \mathrm{H}-\mathrm{NMR}\left(500 \mathrm{MHz} d_{6}\right.$-DMSO) $\delta 7.95\left(1 \mathrm{H}, \mathrm{bs}\right.$, amide NH's), $7.81\left(0.7 \mathrm{H}, \mathrm{d}, J=9.0\left(\mathrm{H} 2^{\prime}\right) \mathrm{Hz}\right.$, $\mathrm{NH}$ 'Ac), $7.74\left(0.9 \mathrm{H}, \mathrm{bs}\right.$, amide $\mathrm{NH}$ 's), $7.46\left(2 \mathrm{H}, \mathrm{bs}, \mathrm{CH}_{2} \mathrm{NHC}(\mathrm{S}) \mathrm{N} H \mathrm{CH}_{2}\right), 5.21(0.7 \mathrm{H}, \mathrm{d}, J=3.2 \mathrm{~Hz}$, H4), $\left.5.17(0.6 \mathrm{H}, \mathrm{s}, \mathrm{H} 4)^{\prime}\right), 5.11(0.7 \mathrm{H}, \mathrm{d}, J=10.3 \mathrm{~Hz}, \mathrm{H} 3), 4.92(0.6 \mathrm{H}, \mathrm{d}, J=10.3 \mathrm{~Hz}, \mathrm{H} 3$ '), $4.89(0.7 \mathrm{H}$, t, $J=9.7 \mathrm{~Hz}, \mathrm{H} 2), 4.69(0.6 \mathrm{H}, \mathrm{d}, J=7.6 \mathrm{~Hz}, \mathrm{H} 1), 4.51\left(0.5 \mathrm{H}, \mathrm{d}, J=8.4 \mathrm{~Hz}, \mathrm{H} 1{ }^{\prime}\right), 4.12(0.8 \mathrm{H}, \mathrm{m}), 4.01$ $(3.2 \mathrm{H}, \mathrm{m}), 3.83(0.7 \mathrm{H}$, app q, $J=8.4,9.0,10.3 \mathrm{~Hz}, \mathrm{H} 2), 3.76(1.7 \mathrm{H}, \mathrm{m}), 3.27-3.59(12 \mathrm{H}, \mathrm{m}), 3.13$ $(3 \mathrm{H}, \mathrm{bs}), 3.04(2.1 \mathrm{H}, \mathrm{bs}), 2.61(5.4 \mathrm{H}, \mathrm{m}), 2.39(2 \mathrm{H}, \mathrm{m}), 2.16(4 \mathrm{H}, \mathrm{bs}), 2.08(3.7 \mathrm{H}, \mathrm{s}), 2.00(5.5 \mathrm{H}, \mathrm{s})$, $1.96(1.7 \mathrm{H}, \mathrm{s}), 1.87(1.6 \mathrm{H}, \mathrm{s}), 1.74(1.4 \mathrm{H}, \mathrm{s}) \mathrm{ppm}$. MALDI-TOF (pos) $\mathrm{m} / \mathrm{z} 119,000$.

9d: ${ }^{1} \mathrm{H}-\mathrm{NMR}\left(500 \mathrm{MHz} d_{6}\right.$-DMSO) $\delta 7.96(1 \mathrm{H}, \mathrm{bs}$, amide NH's), $7.79(0.8 \mathrm{H}, \mathrm{d}, J=9.0 \mathrm{~Hz}, \mathrm{NH}$ 'Ac), $7.74\left(0.7 \mathrm{H}, \mathrm{bs}\right.$, amide NH's), $7.46\left(1.8 \mathrm{H}, \mathrm{m}, \mathrm{CH}_{2} \mathrm{NHC}(\mathrm{S}) \mathrm{NHCH}_{2}\right), 5.21(0.5 \mathrm{H}, \mathrm{s}, \mathrm{H} 4), 5.17(0.6 \mathrm{H}, \mathrm{s}$, H4'), $5.11(0.5 \mathrm{H}, \mathrm{d}, J=10.3 \mathrm{~Hz}, \mathrm{H} 3), 4.92\left(0.6 \mathrm{H}, \mathrm{d}, J=10.3 \mathrm{~Hz}, \mathrm{H} 3{ }^{\prime}\right), 4.89(0.5 \mathrm{H}, \mathrm{t}, J=9.7 \mathrm{~Hz}, \mathrm{H} 2), 4.69$ $(0.4 \mathrm{H}, \mathrm{d}, J=7.6 \mathrm{~Hz}, \mathrm{H1}), 4.51\left(0.6 \mathrm{H}, \mathrm{d}, J=8.4 \mathrm{~Hz}, \mathrm{H} 1^{\prime}\right), 4.12(0.6 \mathrm{H}, \mathrm{m}), 4.01(3.1 \mathrm{H}, \mathrm{m}), 3.83(0.8 \mathrm{H}$, app q, $\left.J=8.4,9.0,10.3 \mathrm{~Hz}, \mathrm{H} 2^{\prime}\right), 3.76(1.5 \mathrm{H}, \mathrm{m}), 3.27-3.59(10 \mathrm{H}, \mathrm{m}), 3.13(2.8 \mathrm{H}, \mathrm{bs}), 3.04(1.7 \mathrm{H}, \mathrm{bs})$, $2.61(4 \mathrm{H}, \mathrm{m}), 2.39(2.2 \mathrm{H}, \mathrm{m}), 2.16(3.5 \mathrm{H}, \mathrm{bs}), 2.07(3.5 \mathrm{H}, \mathrm{s}), 1.98(0.7 \mathrm{H}, \mathrm{s}), 1.96(4.4 \mathrm{H}, \mathrm{s}), 1.87(1.2 \mathrm{H}$, s), $1.85(2 \mathrm{H}, \mathrm{s}), 1.74(1.9 \mathrm{H}, \mathrm{s}) \mathrm{ppm}$. MALDI-TOF (pos) $\mathrm{m} / \mathrm{z} 121,500$.

9e: ${ }^{1} \mathrm{H}-\mathrm{NMR}\left(500 \mathrm{MHz} d_{6}\right.$-DMSO) $\delta 7.95(1 \mathrm{H}, \mathrm{bs}$, amide NH's), $7.79(0.8 \mathrm{H}, \mathrm{d}, J=9.0 \mathrm{~Hz}, \mathrm{NH}$ 'Ac), $7.74\left(0.7 \mathrm{H}, \mathrm{bs}\right.$, amide NH's), $7.46\left(1.6 \mathrm{H}, \mathrm{bs}, \mathrm{CH}_{2} \mathrm{NHC}(\mathrm{S}) \mathrm{NHCH}_{2}\right), 5.21(0.2 \mathrm{H}, \mathrm{d}, J=3.2 \mathrm{~Hz}, \mathrm{H} 4), 5.17$ (0.7H, s, H4'), $5.11(0.3 \mathrm{H}, \mathrm{m}, \mathrm{Hz}, \mathrm{H} 3), 4.92\left(0.7 \mathrm{H}, \mathrm{d}, J=10.3 \mathrm{~Hz}, \mathrm{H} 3{ }^{\prime}\right), 4.89$ (0.2H, t, J = 9.7 Hz, H2), $4.69(0.2 \mathrm{H}, \mathrm{d}, J=7.6 \mathrm{~Hz}, \mathrm{H} 1), 4.51\left(0.7 \mathrm{H}, \mathrm{d}, J=8.4 \mathrm{~Hz}, \mathrm{H} 1{ }^{\prime}\right), 4.12(0.3 \mathrm{H}, \mathrm{m}), 4.01$ (2.9H, m), 3.83 $\left(0.9 \mathrm{H}\right.$, app q, $\left.J=8.4,9.0,10.3 \mathrm{~Hz}, \mathrm{H} 2^{\prime}\right), 3.7(1.2 \mathrm{H}, \mathrm{m}), 3.27-3.59(8.6 \mathrm{H}, \mathrm{m}), 3.04-3.13(2.8 \mathrm{H}, \mathrm{m}), 2.61$ $(3.2 \mathrm{H}, \mathrm{m}), 2.39(1.4 \mathrm{H}, \mathrm{m}), 2.16(2.9 \mathrm{H}, \mathrm{bs}), 2.07(3.2 \mathrm{H}, \mathrm{s}), 1.95(3.9 \mathrm{H}, \mathrm{s}), 1.85(2.9 \mathrm{H}, \mathrm{s}), 1.74(2.2 \mathrm{H}, \mathrm{s})$ ppm. MALDI-TOF (pos) $\mathrm{m} / \mathrm{z} 121,500$.

9f: ${ }^{1} \mathrm{H}-\mathrm{NMR}\left(500 \mathrm{MHz} d_{6}\right.$-DMSO) $\delta 7.96(1 \mathrm{H}, \mathrm{bs}$, amide $\mathrm{NH}$ 's), $7.79(1.1 \mathrm{H}, \mathrm{d}, J=9.0 \mathrm{~Hz}, \mathrm{NH}$ 'Ac), $7.74\left(0.8 \mathrm{H}, \mathrm{bs}\right.$, amide NH's), $7.46\left(2.8 \mathrm{H}, \mathrm{m}, \mathrm{CH}_{2} \mathrm{NHC}(\mathrm{S}) \mathrm{NHCH}_{2}\right), 5.17(1.1 \mathrm{H}, \mathrm{s}, \mathrm{H} 4)$ ') $4.92(1.1 \mathrm{H}, \mathrm{d}$, $\left.J=10.3 \mathrm{~Hz}, \mathrm{H} 3^{\prime}\right), 4.51\left(1.2 \mathrm{H}, \mathrm{d}, J=8.4 \mathrm{~Hz}, \mathrm{H} 1^{\prime}\right), 4.01(4.2 \mathrm{H}, \mathrm{m}), 3.83(1.2 \mathrm{H}$, app q, $J=8.4,9.0,10.3$ Hz, H2'), 3.27-3.59 (12.7H, m), 3.04-3.13 (4.2H, m), $2.61(3.9 \mathrm{H}, \mathrm{m}), 2.16(3.1 \mathrm{H}, \mathrm{bs}), 2.06(4.4 \mathrm{H}, \mathrm{s})$, $1.95(4.1 \mathrm{H}, \mathrm{s}), 1.85(3.7 \mathrm{H}, \mathrm{s}), 1.74(3.8 \mathrm{H}, \mathrm{s}) \mathrm{ppm}$. MALDI-TOF (pos) $\mathrm{m} / z$ 125,000.

Deacetylated

7a: ${ }^{1} \mathrm{H}-\mathrm{NMR}\left(500 \mathrm{MHz} d_{6}\right.$-DMSO) $\delta 8.00$ (bs, 1H), 7.81 (bs, 1H), 7.67 (d, $\left.J=8.6 \mathrm{~Hz}, 0.2 \mathrm{H}\right), 7.50$ (bs, $2.1 \mathrm{H}), 4.95(\mathrm{bs}, 0.7 \mathrm{H}), 4.60-4.70(\mathrm{~m}, 1.5 \mathrm{H}), 4.43(\mathrm{bs}, 0.8 \mathrm{H}), 4.27(\mathrm{~d}, J=8.3 \mathrm{~Hz}, 0.2 \mathrm{H}), 4.11(\mathrm{~d}, J=5.2 \mathrm{~Hz}$, $0.8 \mathrm{H}), 3.84(\mathrm{~m}, 1.0 \mathrm{H}), 3.38-3.65(\mathrm{~m}, 27 \mathrm{H}), 3.17$ (bs, 2.8H), 3.08 (bs, 2.6H), 2.66 (bs, 4.0H), 2.42 (bs, 2.3H), 2.20 (bs, 4.3H), 1.80 (m, 0.9H) ppm. MALDI-TOF (pos) $m / z 15,000$.

7b: ${ }^{1} \mathrm{H}-\mathrm{NMR}\left(500 \mathrm{MHz} d_{6}\right.$-DMSO) $\delta 8.00$ (bs, 1H), 7.80 (bs, 0.9H), 7.67 (d, $\left.J=8.6 \mathrm{~Hz}, 0.3 \mathrm{H}\right), 7.50$ $(\mathrm{m}, 1.5 \mathrm{H}), 4.95(\mathrm{bs}, 0.6 \mathrm{H}), 4.50-4.75(\mathrm{~m}, 2.1 \mathrm{H}), 4.43(\mathrm{bs}, 0.7 \mathrm{H}), 4.27(\mathrm{~d}, J=8.3 \mathrm{~Hz}, 0.4 \mathrm{H}), 4.11(\mathrm{~d}$, 
$J=5.2 \mathrm{~Hz}, 0.7 \mathrm{H}), 3.84(\mathrm{~m}, 0.9 \mathrm{H}), 3.38-3.65(\mathrm{~m}, 24 \mathrm{H}), 3.17(\mathrm{bs}, 2.3 \mathrm{H}), 3.08(\mathrm{bs}, 1.9 \mathrm{H}), 2.66$ (bs, 3.4H), 2.42 (bs, 1.8H), 2.20 (bs, 3.7H), 1.80 (m, 1.0H) ppm. MALDI-TOF (pos) $\mathrm{m} / z$ 15,100.

7c: ${ }^{1} \mathrm{H}-\mathrm{NMR}\left(500 \mathrm{MHz} d_{6}\right.$-DMSO) $\delta 8.01$ (bs, 1H), 7.83 (bs, 0.9H), 7.67 (d, $\left.J=8.6 \mathrm{~Hz}, 0.5 \mathrm{H}\right), 7.59$ (bs, 0.5H), 7.50 (bs, 1.2H), $4.95(\mathrm{bs}, 0.5 \mathrm{H}), 4.60-4.70(\mathrm{~m}, 2.2 \mathrm{H}), 4.43$ (bs, 0.7H), 4.27 (d, J=8.3 Hz, $0.7 \mathrm{H}), 4.11(\mathrm{~d}, J=5.2 \mathrm{~Hz}, 0.6 \mathrm{H}), 3.84(\mathrm{~m}, 1.0 \mathrm{H}), 3.38-3.65(\mathrm{~m}, 30 \mathrm{H}), 3.17(\mathrm{bs}, 3.1 \mathrm{H}), 3.08(\mathrm{bs}, 2.1 \mathrm{H})$, 2.66 (bs, 4.0H), 2.42 (bs, 1.8H), 2.20 (bs, 3.9H), 1.80 (m, 1.6H) ppm. MALDI-TOF (pos) m/z 7,900.

7d: ${ }^{1} \mathrm{H}-\mathrm{NMR}\left(500 \mathrm{MHz} d_{6}\right.$-DMSO) $\delta 8.02$ (bs, 1H), 7.83 (bs, 0.8H), 7.67 (d, $\left.J=8.6 \mathrm{~Hz}, 0.7 \mathrm{H}\right), 7.59$ (bs, 0.6H), $7.50(\mathrm{~m}, 1.1 \mathrm{H}), 4.95(\mathrm{bs}, 0.4 \mathrm{H}), 4.60-4.70(\mathrm{~m}, 2.4 \mathrm{H}), 4.43$ (bs, 0.5H), 4.27 (d, J=8.3 Hz, $0.9 \mathrm{H}), 4.11(\mathrm{~d}, J=5.2 \mathrm{~Hz}, 0.5 \mathrm{H}), 3.38-3.65(\mathrm{~m}, 30 \mathrm{H}), 3.17(\mathrm{bs}, 2.9 \mathrm{H}), 3.08(\mathrm{bs}, 2.0 \mathrm{H}), 2.66$ (bs, 3.9H), 2.42 (bs, 1.9H), 2.20 (bs, 3.9H), 1.80 (m, 2.0H) ppm. MALDI-TOF (pos) $\mathrm{m} / z$ 15,700.

7e: ${ }^{1} \mathrm{H}-\mathrm{NMR}\left(500 \mathrm{MHz} d_{6}\right.$-DMSO) $\delta 8.01$ (bs, 1H), 7.82 (bs, 0.9H), 7.67 (d, $\left.J=8.6 \mathrm{~Hz}, 0.9 \mathrm{H}\right), 7.60$ (bs, 0.8H), 7.50 (bs, 0.7H), $4.95(\mathrm{bs}, 0.2 \mathrm{H}), 4.60-4.70(\mathrm{~m}, 2.6 \mathrm{H}), 4.43$ (bs, 0.2H), 4.27 (d, J=8.3 Hz, $1.0 \mathrm{H}), 4.11(\mathrm{~d}, J=5.2 \mathrm{~Hz}, 0.3 \mathrm{H}), 3.38-3.65(\mathrm{~m}, 23 \mathrm{H}), 3.17$ (bs, 2.6H), 3.08 (bs, 2.61), 2.66 (bs, 3.9H), 2.42 (bs, 1.7H), 2.20 (bs, 3.7H), $1.80(\mathrm{~m}, 2.6 \mathrm{H}) \mathrm{ppm}$. MALDI-TOF (pos) $\mathrm{m} / z$ 15,800.

7f: ${ }^{1} \mathrm{H}-\mathrm{NMR}(500 \mathrm{MHz} d 6$-DMSO) $\delta 8.01(\mathrm{bs}, 1 \mathrm{H}), 7.82(\mathrm{bs}, 0.9 \mathrm{H}), 7.68$ (d, $J=8.6 \mathrm{~Hz}, 1.0 \mathrm{H}), 7.59$ (bs, $0.9 \mathrm{H}), 7.50(\mathrm{~m}, 1.0 \mathrm{H}), 4.60-4.70(\mathrm{~m}, 2.8 \mathrm{H}), 4.27(\mathrm{~d}, J=8.3 \mathrm{~Hz}, 1.1 \mathrm{H}), 3.77(\mathrm{~m}, 3.3 \mathrm{H}), 3.38-3.65$ (m, 30H), 3.17 (bs, 3.3H), 3.10 (bs, 1.9H), 2.66 (bs, 4.1H), 2.42 (bs, 1.9H), 2.20 (bs, 3.8H), 1.80 (m, $3.0 \mathrm{H}) \mathrm{ppm}$. MALDI-TOF (pos) $\mathrm{m} / \mathrm{z} 16,400$.

8a: ${ }^{1} \mathrm{H}-\mathrm{NMR}\left(500 \mathrm{MHz} d_{6}\right.$-DMSO) $\delta 8.01$ (bs, 1H), 7.81 (bs, 1H), $7.67(\mathrm{~m}, 0.2 \mathrm{H}), 7.50$ (bs, 1.8H), $4.95(\mathrm{bs}, 0.6 \mathrm{H}), 4.60-4.70(\mathrm{~m}, 2.0 \mathrm{H}), 4.43(\mathrm{bs}, 0.9 \mathrm{H}), 4.27(\mathrm{~m}, 0.2 \mathrm{H}), 4.11(\mathrm{~m}, 0.8 \mathrm{H}), 3.84(\mathrm{~m}, 1.0 \mathrm{H})$, $3.38-3.65(\mathrm{~m}, 30 \mathrm{H}), 3.17(\mathrm{bs}, 2.5 \mathrm{H}), 3.08(\mathrm{bs}, 2.6 \mathrm{H}), 2.66(\mathrm{bs}, 3.9 \mathrm{H}), 2.42(\mathrm{bs}, 2.1 \mathrm{H}), 2.20(\mathrm{bs}, 4.1 \mathrm{H})$, $1.80(\mathrm{~m}, 0.7 \mathrm{H}) \mathrm{ppm} .31,200$.

8b: ${ }^{1} \mathrm{H}-\mathrm{NMR}\left(500 \mathrm{MHz} d_{6}\right.$-DMSO) $\delta 8.03$ (bs, 1H), 7.85 (bs, 0.9H), 7.73 (d, J=8.6 Hz, 0.4H), 7.50 $(\mathrm{m}, 1.6 \mathrm{H}), 4.95(\mathrm{bs}, 0.4 \mathrm{H}), 4.50-4.90(\mathrm{~m}, 2.3 \mathrm{H}), 4.52(\mathrm{bs}, 0.6 \mathrm{H}), 4.27$ (d, J=8.3 Hz, 0.5H), 4.12 (s, $0.9 \mathrm{H}), 3.38-3.70(\mathrm{~m}, 30 \mathrm{H}), 3.17$ (bs, 2.7H), 3.08 (bs, 2.1H), 2.66 (bs, 3.8H), 2.42 (bs, 1.8H), 2.20 (bs, $3.9 \mathrm{H}), 1.80$ (m, 1.2H) ppm. MALDI-TOF (pos) $m / z 31,700$.

8c: ${ }^{1} \mathrm{H}-\mathrm{NMR}\left(500 \mathrm{MHz} d_{6}\right.$-DMSO) $\delta 8.02$ (bs, 1H), 7.83 (bs, 0.9H), 7.71 (m, 0.5H), 7.58 (bs, 0.6H), 7.50 (bs, 1.0H), 4.95 (bs, 0.3H), 4.60-4.70 (m, 1.7H), 4.58 (bs, 0.5H), 4.48 (bs, 0.5H), 4.27 (d, $J=8.3$ $\mathrm{Hz}, 0.5 \mathrm{H}), 4.11(\mathrm{~m}, 0.4 \mathrm{H}), 3.84(\mathrm{~m}, 1.6 \mathrm{H}), 3.38-3.65(\mathrm{~m}, 30 \mathrm{H}), 3.17(\mathrm{bs}, 2.4 \mathrm{H}), 3.08$ (bs, 2.1H), 2.66 (bs, 3.8H), 2.42 (bs, 1.7H), 2.20 (bs, 4.0H), 1.80 (m, 1.8H) ppm. MALDI-TOF (pos) m/z 33,000.

8d: ${ }^{1} \mathrm{H}-\mathrm{NMR}\left(500 \mathrm{MHz} d_{6}\right.$-DMSO) $\delta 8.02$ (bs, 1H), 7.83 (bs, 0.8H), 7.67 (d, J=8.6 Hz, 0.8H), 7.58 (bs, 0.7H), $7.43(\mathrm{~m}, 0.9 \mathrm{H}), 4.95(\mathrm{bs}, 0.1 \mathrm{H}), 4.69$ (bs, 1.7H), 4.58 (bs, 0.8H), 4.43 (bs, 0.2H), 4.27 (d, $J=$ $8.3 \mathrm{~Hz}, 0.8 \mathrm{H}), 4.11(\mathrm{~m}, 0.1 \mathrm{H}), 3.38-3.65(\mathrm{~m}, 30 \mathrm{H}), 3.17(\mathrm{bs}, 2.5 \mathrm{H}), 3.08(\mathrm{bs}, 1.8 \mathrm{H}), 2.66(\mathrm{bs}, 4.1 \mathrm{H})$, 2.42 (bs, 1.8H), 2.21 (bs, 3.8H), 1.80 (m, 2.2H) ppm. MALDI-TOF (pos) $m / z$ 34,300. 
8e: ${ }^{1} \mathrm{H}-\mathrm{NMR}\left(500 \mathrm{MHz} d_{6}\right.$-DMSO) $\delta 8.02$ (bs, 1H), 7.83 (bs, 0.8H), 7.67 (d, $\left.J=8.6 \mathrm{~Hz}, 0.9 \mathrm{H}\right), 7.58$ (bs, 0.8H), $7.44(\mathrm{bs}, 0.8 \mathrm{H}), 4.68(\mathrm{~m}, 1.5 \mathrm{H}), 4.58(1.0 \mathrm{H}), 4.27(\mathrm{~d}, J=8.3 \mathrm{~Hz}, 0.9 \mathrm{H}), 3.38-3.65$ (m, 23H), 3.17 (bs, 2.4H), 3.08 (bs, 1.9H), 2.66 (bs, 3.8H), 2.42 (bs, 1.6H), 2.20 (bs, 3.8H), 1.80 (m, 2.8H) ppm. MALDI-TOF (pos) $\mathrm{m} / \mathrm{z} 34,300$.

8f: ${ }^{1} \mathrm{H}-\mathrm{NMR}\left(500 \mathrm{MHz} d_{6}\right.$-DMSO) $\delta 8.02$ (bs, $\left.1 \mathrm{H}\right), 7.83$ (bs, 0.8H), 7.69 (d, $\left.J=8.6 \mathrm{~Hz}, 0.8 \mathrm{H}\right), 7.58$ (bs, $0.8 \mathrm{H}), 7.43(\mathrm{~m}, 0.9 \mathrm{H}), 4.67(\mathrm{~m}, 1.6 \mathrm{H}), 4.58(\mathrm{bs}, 0.8 \mathrm{H}), 4.27(\mathrm{~d}, J=8.3 \mathrm{~Hz}, 0.8 \mathrm{H}), 3.38-3.65(\mathrm{~m}, 30 \mathrm{H})$, 3.10-3.17 (m, 4.6H), 2.66 (bs, 3.7H), 2.42 (bs, 1.6H), 2.20 (bs, 3.6H), 1.80 (m, 2.4H) ppm. MALDI-TOF (pos) $m / z 33,300$.

9a: ${ }^{1} \mathrm{H}-\mathrm{NMR}\left(500 \mathrm{MHz} d_{6}\right.$-DMSO) $\delta 8.01$ (bs, 1H), $7.83(\mathrm{bs}, 0.7 \mathrm{H}), 7.67$ (m, 0.2H), 7.48 (bs, 1.5H), $5.04(\mathrm{bs}, 0.7 \mathrm{H}), 4.60-4.70(\mathrm{~m}, 1.7 \mathrm{H}), 4.43(\mathrm{bs}, 0.8 \mathrm{H}), 4.28(\mathrm{~m}, 0.2 \mathrm{H}), 4.11(\mathrm{~s}, 1.0 \mathrm{H}), 3.84(\mathrm{~m}, 2.0 \mathrm{H})$, 3.38-3.65 (m, 30H), 3.17 (bs, 2.1H), 3.08 (bs, 1.7H), $2.65(\mathrm{bs}, 3.2 \mathrm{H}), 2.42$ (bs, 1.4H), 2.20 (bs, 3.5H), $1.80(\mathrm{~m}, 0.6 \mathrm{H}) \mathrm{ppm}$. MALDI-TOF (pos) $\mathrm{m} / \mathrm{z} 100,000$.

9b: ${ }^{1} \mathrm{H}-\mathrm{NMR}\left(500 \mathrm{MHz} d_{6}\right.$-DMSO) $\delta 8.03$ (bs, 1H), 7.85 (bs, 0.7H), 7.73 (s, 0.3H), 7.47 (m, 1.4H), $5.07(\mathrm{bs}, 0.5 \mathrm{H}), 4.68-4.90(\mathrm{~m}, 1.7 \mathrm{H}), 4.63(\mathrm{bs}, 0.4 \mathrm{H}), 4.54(\mathrm{bs}, 0.6 \mathrm{H}), 4.27(\mathrm{~s}, 0.4 \mathrm{H}), 4.12(\mathrm{~s}, 0.9 \mathrm{H})$, 3.38-3.70 (m, 30H), 3.17 (bs, 2.2H), 3.08 (bs, 1.6H), 2.66 (bs, 2.8H), 2.20 (bs, 3.4H), 1.80 (m, 1.2H) ppm. MALDI-TOF (pos) $m / z$ 101,000.

9c: ${ }^{1} \mathrm{H}-\mathrm{NMR}\left(500 \mathrm{MHz} d_{6}\right.$-DMSO) $\delta 8.02$ (bs, 1H), 7.84 (bs, 0.7H), 7.72 (s, 0.5H), 7.58 (bs, 0.5H), $7.44(\mathrm{bs}, 0.9 \mathrm{H}), 5.04(\mathrm{bs}, 0.3 \mathrm{H}), 4.72(\mathrm{~m}, 1.7 \mathrm{H}), 4.61(\mathrm{bs}, 0.8 \mathrm{H}), 4.28(\mathrm{~s}, 0.6 \mathrm{H}), 4.13(\mathrm{~m}, 0.4 \mathrm{H}), 3.38-3.80$ (m, 30H), 3.10-3.17 (m, 3.5H), 2.66 (bs, 3.0H), 2.42 (bs, 1.0H), 2.20 (bs, 3.4H), 1.80 (m, 1.5H) ppm. MALDI-TOF (pos) $\mathrm{m} / \mathrm{z}$ 101,500.

9d: ${ }^{1} \mathrm{H}-\mathrm{NMR}(500 \mathrm{MHz} d 6-\mathrm{DMSO}) \delta 8.02(\mathrm{bs}, 1 \mathrm{H}), 7.84(\mathrm{bs}, 0.8 \mathrm{H}), 7.72(\mathrm{~s}, 0.4 \mathrm{H}), 7.57$ (bs, 0.5H), $7.48(\mathrm{~m}, 0.9 \mathrm{H}), 5.05$ (bs, 0.4H), 4.69 (bs, $1.6 \mathrm{H}), 4.58$ (bs, $0.5 \mathrm{H}), 4.43$ (bs, 0.2H), 4.27 (s, 0.5H), 4.13 (m, 0.5H), 3.38-3.65 (m, 30H), 3.10-3.17 (bs, 3.6H), 2.66 (bs, 3.0H), 2.42 (bs, 1.3H), 2.21 (bs, 3.3H), $1.82(\mathrm{~m}, 1.4 \mathrm{H}) \mathrm{ppm}$. MALDI-TOF (pos) $\mathrm{m} / \mathrm{z} 102,000$.

9e: ${ }^{1} \mathrm{H}-\mathrm{NMR}\left(500 \mathrm{MHz} d_{6}\right.$-DMSO) $\delta 8.02$ (bs, 1H), $7.82(\mathrm{bs}, 0.7 \mathrm{H}), 7.67(\mathrm{~s}, 0.7 \mathrm{H}), 7.58$ (bs, 0.7H), 7.44 (bs, 0.8H), 5.05 (bs, 0.2H), $4.68(\mathrm{~m}, 1.7 \mathrm{H}), 4.60(0.7 \mathrm{H}), 4.28(\mathrm{~s}, 0.7 \mathrm{H}), 3.38-3.65(\mathrm{~m}, 23 \mathrm{H}), 3.10-3.17$ $(\mathrm{m}, 3.6 \mathrm{H}), 2.66(\mathrm{bs}, 2.9 \mathrm{H}), 2.42(\mathrm{bs}, 0.8 \mathrm{H}), 2.21(\mathrm{bs}, 3.2 \mathrm{H}), 1.80(\mathrm{~m}, 1.8 \mathrm{H}) \mathrm{ppm}$. MALDI-TOF (pos) $\mathrm{m} / \mathrm{z} 106,500$.

9f: ${ }^{1} \mathrm{H}-\mathrm{NMR}\left(500 \mathrm{MHz} d_{6}\right.$-DMSO) $\delta 8.03(\mathrm{bs}, 1 \mathrm{H}), 7.84(\mathrm{bs}, 0.7 \mathrm{H}), 7.72(\mathrm{~s}, 0.8 \mathrm{H}), 7.58$ (bs, 0.7H), $7.43(\mathrm{~m}, 0.9 \mathrm{H}), 4.73(\mathrm{~m}, 1.6 \mathrm{H}), 4.62(\mathrm{bs}, 0.9 \mathrm{H}), 4.27(\mathrm{~s}, 0.8 \mathrm{H}), 3.38-3.65(\mathrm{~m}, 30 \mathrm{H}), 3.10-3.17(\mathrm{~m}$, $3.8 \mathrm{H}), 2.66(\mathrm{bs}, 3.0 \mathrm{H}), 2.42(\mathrm{bs}, 1.2 \mathrm{H}), 2.21(\mathrm{bs}, 3.5 \mathrm{H}), 1.80(\mathrm{~m}, 2.2 \mathrm{H}) \mathrm{ppm}$. MALDI-TOF (pos) $m / z 107,500$. 


\subsection{ELISA Methods}

\subsubsection{Preparation of Glycodendrimer Adsorbed 96 well Plates}

Glycodendrimer was dissolved into PBS ( $\mathrm{pH} 7.4,15 \mathrm{mmol} \mathrm{NaCl}$ ). The stock solution was commonly prepared at $5 \mathrm{mg} / \mathrm{mL}$, but the concentration of the stock solution was reduced if there were problems with solubility. To each well of a Nunc MaxiSorp 96 well plate (Thermo Scientific, Waltham, MA, USA), $50 \mu \mathrm{L}$ of a $0.025 \mathrm{mg} / \mathrm{mL}$ solution was added. The well plate was covered and stored for $24 \mathrm{~h}$ at $4{ }^{\circ} \mathrm{C}$. The solvent was removed from the well plate and $250 \mu \mathrm{L}$ of $3 \%$ BSA solution in PBS (pH 7.4, $15 \mathrm{mmol} \mathrm{NaCl}$ ) was added to each well plate to block non-specific interactions. The plate was covered and let stand for $2 \mathrm{~h}$ at RT. After $2 \mathrm{~h}$, the plate was emptied, washed once with PBS (pH 7.4, $15 \mathrm{mmol}$ $\mathrm{NaCl}$ ), and dried. Dried plates were either used immediately or covered and stored at $4{ }^{\circ} \mathrm{C}$ for later use.

\subsubsection{ELISA to Study Galectin-3 Binding Interactions with Glycodendrimers}

In a PPI plate, $60 \mu \mathrm{L}$ of $0.5 \%$ BSA in PBS (pH 7.4) was added to each well, except A1, C1, E1 and G1. To A1, C1, E1, and G1, $60 \mu \mathrm{L}$ of $100 \mathrm{mg} / \mathrm{mL}$ lactose solution were added. To A2, C2, E2, and G2, $60 \mu \mathrm{L}$ of the $100 \mathrm{mg} / \mathrm{mL}$ lactose solution were added. To generate 24 sequential lactose concentrations, serial dilutions were performed, starting with wells $\mathrm{A} 2, \mathrm{D} 2$, and $\mathrm{G} 2$, so that $60 \mu \mathrm{L}$ remained in each well. From each well, $50 \mu \mathrm{L}$ were transferred to the corresponding well on the glycodendrimer coated prepared plate (preparation of the glycodendrimer coated plate is described above in 4.1.1.). Galectin-3 was added (50 $\mu \mathrm{L}$ of $10 \mu \mathrm{g} / \mathrm{mL}$ solution, concentration determined using a BCA assay [88]), the plate was covered and placed on an agitator/shaker for $45 \mathrm{~min}$.

After $45 \mathrm{~min}$, the plate was removed from the shaker and the contents were emptied. Each well was washed $2 \times$ with PBS-T (pH 7.4) and $1 \times$ with PBS (pH 7.4). Biotinylated anti-galectin-3 was added (50 $\mu \mathrm{L}$ of a 1:100 dilution of $1 \mathrm{~mL}$ stock from R and D Systems, Inc., Minneapolis, MN, USA), the plate was covered and placed back on the shaker for $45 \mathrm{~min}$. After $45 \mathrm{~min}$, the plate was removed from the shaker and the wells were emptied and each well was washed $2 \times$ with PBS-T (pH 7.4) and $1 \times$ with PBS ( $\mathrm{pH}$ 7.4). Horseradish peroxidase streptavidin conjugate was added $(100 \mu \mathrm{L}$ of solution that was a 1:200 dilution from the stock obtained from BD Biosciences, Seattle, WA, USA), and the plate was covered and placed on the shaker for $45 \mathrm{~min}$. The plate was removed from the shaker, the wells were emptied and each well was washed $2 \times$ with PBS-T (pH 7.4) and $1 \times$ with PBS (pH 7.4).

TMB (tetramethylbenzidene): peroxide solution $(100 \mu \mathrm{L}$ of a 1:1 mix of solutions from kit purchased from BD biosciences) was added and the color change was observed. $100 \mu \mathrm{L}$ of $1 \mathrm{M}$ phosphoric acid was added to stop the reaction (This can be monitored at $620 \mathrm{~nm}$ on a plate reader). Absorbances were read at $450 \mathrm{~nm}$ for each well plate, with the reference at $620 \mathrm{~nm}$.

\subsubsection{ELISA to Study Galectin-1 Binding Interactions with Glycodendrimers}

To a processed polystyrene (PPI) plate, $60 \mu \mathrm{L}$ of $0.5 \%$ BSA in PBS (pH 7.4, $15 \mathrm{mM} \mathrm{NaCl}$ ) were added to all wells, except A1, D1 and G1. Wells A1, D1, and G1 were filled with $60 \mu \mathrm{L}$ of a $100 \mathrm{mg} / \mathrm{mL}$ lactose solution. To wells A2, D2, and G2, $60 \mu \mathrm{L}$ of a $100 \mathrm{mg} / \mathrm{mL}$ lactose solution were added. To generate 24 sequential lactose concentrations, serial dilutions were performed, starting with wells A2, 
D2, and G2, so that $60 \mu \mathrm{L}$ remained in each well. From each well on the PPI plate, $50 \mu \mathrm{L}$ were transferred to the corresponding well on the glycodendrimer coated plate (preparation of the glycodendrimer coated plate is described above in 3.6.1.). To all wells, biotinylated galectin-1 (50 $\mu \mathrm{L}$ of a $5.0 \mu \mathrm{g} / \mathrm{mL}$ solution) was added (biotinylation of galectin-1 is described in Section 3.4). The plate was covered and placed on a shaker/agitator for $45 \mathrm{~min}$.

After $45 \mathrm{~min}$, the plate was emptied and washed, twice with PBS-T (pH 7.4, $15 \mathrm{mM} \mathrm{NaCl}$ ) and once with PBS ( $\mathrm{pH} 7.4,15 \mathrm{mM} \mathrm{NaCl}$ ). $100 \mu \mathrm{L}$ of streptavidin-horseradish peroxidase (SAv-HRP) (1:1000 dilution of the stock purchased from BD Biosciences) were added to each well. The plate was covered and placed on a shaker/agitator for $45 \mathrm{~min}$.

After $45 \mathrm{~min}$, the plate was emptied and washed, twice with PBS-T (pH 7.4, $15 \mathrm{mM} \mathrm{NaCl}$ ) and once with PBS ( $\mathrm{pH} 7.4,15 \mathrm{mM} \mathrm{NaCl}$ ). $100 \mu \mathrm{L}$ of $\mathrm{TMB} / \mathrm{H}_{2} \mathrm{O}_{2}$ (mixed in a 1:1 ratio from a kit purchased from BD Biosciences) were added to each well. The plate was covered and incubated for $10 \mathrm{~min}$. A blue color change was observed. After $10 \mathrm{~min}, 100 \mu \mathrm{L}$ of $\mathrm{H}_{3} \mathrm{PO}_{4}$ was added to each well and a yellow color change was observed. Absorbances were measured at $450 \mathrm{~nm}$, with a reference at $620 \mathrm{~nm}$.

\subsubsection{Analysis of ELISA Binding Curves}

Data collected from the ELISAs were analysed with GraphPad Prism software (Version 5, GraphPad Software, Inc. La Jolla, CA, USA), which generated logarithmic binding curves as a function of the log of the concentration of lactose $(\mathrm{mM})$.

\subsection{X-ray Photoelectron Spectroscopy (XPS)}

X-ray photoelectron spectroscopy was used to analyze the amount of glycodendrimer that adsorbed to the Nunc MaxiSorp 96 well plate (Thermo Scientific, Waltham, MA, USA) surface. Experiments were performed with compounds $4 \mathbf{a}, 5 \mathbf{5}, \mathbf{6 a}, \mathbf{4 f}, \mathbf{5 f}, \mathbf{6 f}$. To monitor the amount of glycodendrimer adsorbed to the plate, the amount of nitrogen was used as a quantitative measurement. Since the Nunc MaxiSorp plates have oxygen in the surface coating to facilitate surface adsorption, a background signal in the oxygen spectrum is always present. The entire nitrogen spectrum, however, is due solely to the glycodendrimer. The XPS experiments were performed with higher concentrations of glycodendrimer than the ELISA to increase the adsorbed glycodendrimer to the plate surface, hence increasing the signal in the nitrogen spectrum. Experiments with very high amounts of dendrimer in the solution during the adsorption revealed little or no difference between $5 \mu \mathrm{mol}$ and $50 \mu \mathrm{mol}$ solutions, with $5 \mu \mathrm{mol}$ being the optimal and preferred concentration for XPS experiments. The ELISA assay adsorption concentration was $250 \mathrm{nmol}$; at this concentration the same XPS trends were observed although the nitrogen signal was decreased and the sulfur signal was too small to be observable.

Carbohydrate functionalized dendrimers were dissolved in a PBS solution at $1 \mathrm{mg} / \mathrm{mL}$ concentration, which required $24 \mathrm{~h}$ of stirring. These solutions were diluted with PBS buffer to a concentration of $5 \mu \mathrm{M}$. $50 \mu \mathrm{L}$ of this solution was added to a well of a Nunc MaxiSorp 96 well plate, covered and stored at $5{ }^{\circ} \mathrm{C}$ for $20 \mathrm{~h}$. The well was washed with PBS twice and washed with nanopure water twice to remove any phosphate buffer that might interfere with the analysis. The bottom of the well plate was removed with scissors and was used for XPS analysis. The analysis was conducted on a Physical Electronics 5600ci 
XPS system equipped with monochromatized Al KR X-rays. The analysis area of the sample was $0.8 \mathrm{~mm}$ in diameter. Electron emissions were collected at $45^{\circ}$ to the normal of the surface, and the sphericalsector-analyser pass energy was selected as $11.75 \mathrm{eV}$ for high-resolution scanning and as $46.95 \mathrm{eV}$ for a survey to achieve optimum energy resolution and count rate. The data acquisition and data analysis were performed using RBD AugerScan 2 software (Version 2, RBD Instruments, Bend, OR, USA).

\section{Conclusions}

In summary, generation three, four, and six PAMAM dendrimers bearing heterogeneous mixtures of $\beta$-galactoside, $\beta$-GalNAc, and $\beta$-lactoside were synthesized and characterized. This small library of glycodendrimers was used to assess multivalent effects in a complex carbohydrate/galectin-3 interaction. A modified ELISA based experiment was developed to further the understanding of how galectin-3 binds to carbohydrates. This assay revealed that galectin-3 interacts with glycodendrimers in a markedly different way than it interacts with monomeric sugars. The multivalent binding constants that were determined using the modified ELISA assay for the dendrimers with galectin-3 are all very similar, even with sugar epitopes that have binding constants that differ by almost two orders of magnitude. However, the modified ELISA revealed that galectin-3 recruitment was directly dependent on the ratio of low to high affinity ligands on the dendrimers. To validate the utility of the modified ELISA for study of multivalent binding by galectins, lactose functionalized dendrimers of three generations of dendrimers were studied in the same modified ELISA format with galectin-1. Galectin1 recruitment was shown to be dependent on dendrimer generation/valency, while IC50 values were determined to be consistent regardless of the generation of dendrimer that was used. The results with galectin-1 and galectin-3 are highly complementary and indicate the prevalence of a multivalent binding interaction between glycodendrimers and these galectins.

The observations detailed here indicate that multivalent architectures are likely to be critical for improving the understanding of the behaviour of the galectins in biological recognition events. These results suggest that the binding affinity may play less of a role in galectin mediated processes than clustering and aggregation mechanisms. In general, an in-depth understanding of the aggregation that occurs in complex systems requires studies using many different assays in many different formats. Because of the complexity and the high prevalence of biologically relevant multivalent interactions, relatively straightforward ways of describing, defining, and characterizing multivalent proteincarbohydrate interactions such as this modified ELISA are essential.

\section{Supplementary Materials}

Supplementary materials can be accessed at: http://www.mdpi.com/1420-3049/20/04/7059/s1.

\section{Acknowledgments}

We would like to thank Linda Baum and Mabel Pang (UCLA) for providing the galectin-1, Recep Avci and the Imaging and Chemical Analysis Laboratory at MSU for guidance with XPS, and Julie Sprenger, Julianna Weiel, Candace Goodman, and Kylene Compton for producing galectin-3. This research was supported by NIH GM62444. 


\section{Author Contributions}

M.C. and A.R. conceived the ideas for this study and M.W., J.C., and M.C. designed the experiments. M.W. conducted the syntheses, the galectin-3 ELISAs, and the XPS experiments. J.C. conducted the galectin-1 ELISAs. P.N.-M. assisted with the galectin-3 isolation and handling. M.W., J.C., A.R., and M.C. wrote the manuscript.

\section{Conflicts of Interest}

The authors declare no conflict of interest.

\section{References}

1. Mammen, M.; Choi, S.K.; Whitesides, G.M. Polyvalent interactions in biological systems: Implications for design and use of multivalent ligands and inhibitors. Angew. Chem. Int. Ed. 1998, $37,2755-2794$.

2. Gestwicki, J.E.; Strong, L.E.; Cairo, C.W.; Boehm, F.J.; Kiessling, L.L. Cell aggregation by scaffolded receptor clusters. Chem. Biol. 2002, 9, 163-169.

3. Disney, M.D.; Zheng, J.; Swager, T.M.; Seeberger, P.H. Detection of bacteria with carbohydrate-functionalized fluorescent polymers. J. Am. Chem. Soc. 2004, 126, 13343-13346.

4. Yilmaz, G.; Becer, C.R. Precision glycopolymers and their interactions with lectins. Eur. Polym. J. 2013, 49, 3046-3051.

5. Kitov, P.I.; Sadowska, J.M.; Mulvey, G.; Armstrong, G.D.; Ling, H.; Pannu, N.S.; Read, R.J.; Bundle, D.R. Shiga-like toxins are neutralized by tailored multivalent carbohydrate ligands. Nature 2000, 403, 669-672.

6. Chen, Y.; Chen, G.; Stenzel, M.H. Synthesis and Lectin Recognition of Glyco Star Polymers Prepared by "Clicking" Thiocarbohydrates onto a Reactive Scaffold. Macromolecules 2010, 43, 8109-8114.

7. Zhang, Q.; Su, L.; Collins, J.; Chen, G.; Wallis, R.; Mitchell, D.A.; Haddleton, D.M.; Becer, C.R. Dendritic Cell Lectin-Targeting Sentinel-like Unimolecular Glycoconjugates To Release an AntiHIV Drug. J. Am. Chem. Soc. 2014, 136, 4325-4332.

8. Yang, W.; Pan, C.-Y.; Luo, M.-D.; Zhang, H.-B. Fluorescent Mannose-Functionalized Hyperbranched Poly(amido amine)s: Synthesis and Interaction with E. coli. Biomacromolecules 2010, 11, 1840-1846.

9. Lin, K.; Kasko, A.M. Effect of Branching Density on Avidity of Hyperbranched Glycomimetics for Mannose Binding Lectin. Biomacromolecules 2013, 14, 350-357.

10. Papp, I.; Dernedde, J.; Enders, S.; Riese, S.B.; Shiao, T.C.; Roy, R.; Haag, R. Multivalent Presentation of Mannose on Hyperbranched Polyglycerol and their Interaction with Concanavalin A Lectin. ChemBioChem 2011, 12, 1075-1083.

11. Chien, Y.-Y.; Jan, M.-D.; Adak, A.K.; Tzeng, H.-C.; Lin, Y.-P.; Chen, Y.-J.; Wang, K.-T.; Chen, C.-T.; Chen, C.-C.; Lin, C.-C. Globotriose-functionalized gold nanoparticles as multivalent probes for Shiga-like toxin. ChemBioChem 2008, 9, 1100-1109.

12. Wang, X.; Ramstrom, O.; Yan, M. Quantitative Analysis of Multivalent Ligand Presentation on Gold Glyconanoparticles and the Impact on Lectin Binding. Anal. Chem. 2010, 82, 9082-9089. 
13. Brinas, R.P.; Sundgren, A.; Sahoo, P.; Morey, S.; Rittenhouse-Olson, K.; Wilding, G.E.; Deng, W.; Barchi, J.J., Jr. Design and Synthesis of Multifunctional Gold Nanoparticles Bearing TumorAssociated Glycopeptide Antigens as Potential Cancer Vaccines. Bioconjugate Chem. 2012, 23, 1513-1523.

14. Chabre, Y.M.; Roy, R. Recent trends in glycodendrimer syntheses and applications. Curr. Top. Med. Chem. 2008, 8, 1237-1285.

15. Johansson, S.M.C.; Arnberg, N.; Elofsson, M.; Wadell, G.; Kihlberg, J. Multivalent HSA conjugates of 3'-siallyllactose are potent inhibitors of adenoviral cell attachment and infection. ChemBioChem 2005, 6, 358-364.

16. Sun, X.L.; Cui, W.X.; Haller, C.; Chaikof, E.L. Site-specific multivalent carbohydrate labeling of quantum dots and magnetic beads. ChemBioChem 2004, 5, 1593-1596.

17. Song, X.; Xia, B.; Stowell, S.R.; Lasanajak, Y.; Smith, D.F.; Cummings, R.D. Novel Fluorescent Glycan Microarray Strategy Reveals Ligands for Galectins. Chem. Biol. 2009, 16, 36-47.

18. Oyelaran, O.; Li, Q.; Farnsworth, D.; Gildersleeve, J.C. Microarrays with Varying Carbohydrate Density Reveal Distinct Subpopulations of Serum Antibodies. J. Proteome Res. 2009, 8, 3529-3538.

19. Zheng, H.; Du, X. Multivalent protein binding in carbohydrate-functionalized monolayers through protein-directed rearrangement and reorientation of glycolipids at the air-water interface. Biochim. Biophys. Acta Biomembr. 2011, 1808, 2128-2135.

20. Park, H.; Rosencrantz, R.R.; Elling, L.; Boeker, A. Glycopolymer Brushes for Specific Lectin Binding by Controlled Multivalent Presentation of N-Acetyllactosamine Glycan Oligomers. Macromol. Rapid Commun. 2015, 36, 45-54.

21. Choi, S.K. Synthetic Multivalent Molecules: Concepts and Biomedical Applications; Wiley: Hoboken, NJ, USA, 2004.

22. Michel, A.K.; Nangia-Makker, P.; Raz, A.; Cloninger, M.J. Lactose-Functionalized Dendrimers Arbitrate the Interaction of Galectin-3/MUC1 Mediated Cancer Cellular Aggregation. ChemBioChem 2014, 15, 2106-2112.

23. Vonnemann, J.; Liese, S.; Kuehne, C.; Ludwig, K.; Dernedde, J.; Böttcher, C.; Netz, R.R.; Haag, R. Size-dependence of steric shielding and multivalency effects for globular binding inhibitors. J. Am. Chem. Soc. 2015, 137, 2572-2579.

24. Laurino, P.; Kikkeri, R.; Azzouz, N.; Seeberger, P.H. Detection of Bacteria Using Glyco-Dendronized Polylysine Prepared by Continuous Flow Photofunctionalization. Nano Lett. 2011, 11, 73-78.

25. Kiessling, L.L.; Gestwicki, J.E.; Strong, L.E. Synthetic multivalent ligands as probes of signal transduction. Angew. Chem. Int. Ed. 2006, 45, 2348-2368.

26. Bhatia, S.; Dimde, M.; Haag, R. Multivalent glycoconjugates as vaccines and potential drug candidates. MedChemComm 2014, 5, 862-878.

27. Schlick, K.H.; Cloninger, M.J. Inhibition binding studies of glycodendrimer/lectin interactions using surface plasmon resonance. Tetrahedron 2010, 66, 5305-5310.

28. Kim, H.J.; Brennan, P.J.; Heaslip, D.; Udey, M.C.; Modlin, R.L.; Belisle, J.T. CarbohydrateDependent Binding of Langerin to SodC, a Cell Wall Glycoprotein of Mycobacterium leprae. $J$. Bacteriol. 2015, 197, 615-625. 
29. Kussrow, A.; Kaltgrad, E.; Wolfenden, M.L.; Cloninger, M.J.; Finn, M.G.; Bornhop, D.J. Measurement of Monovalent and Polyvalent Carbohydrate-Lectin Binding by Back-Scattering Interferometry. Anal. Chem. 2009, 81, 4889-4897.

30. Godula, K.; Bertozzi, C.R. Density Variant Glycan Microarray for Evaluating Cross-Linking of Mucin-like Glycoconjugates by Lectins. J. Am. Chem. Soc. 2012, 134, 15732-15742.

31. Valtola, L.; Rahikkala, A.; Raula, J.; Kauppinen, E.I.; Tenhu, H.; Hietala, S. Synthesis and lectin recognition of glycosylated amphiphilic nanoparticles. Eur. Polym. J. 2014, 59, 282-289.

32. Schlick, K.H.; Lange, C.K.; Gillispie, G.D.; Cloninger, M.J. Characterization of Protein Aggregation via Intrinsic Fluorescence Lifetime. J. Am. Chem. Soc. 2009, 131, 16608-16609.

33. Cummins, B.M.; Li, M.; Locke, A.K.; Birch, D.J.S.; Vigh, G.; Cote, G.L. Overcoming the aggregation problem: A new type of fluorescent ligand for ConA-based glucose sensing. Biosens. Bioelectron. 2015, 63, 53-60.

34. Belardi, B.; O'Donoghue, G.P.; Smith, A.W.; Groves, J.T.; Bertozzi, C.R. Investigating Cell Surface Galectin-Mediated Cross-Linking on Glycoengineered Cells. J. Am. Chem. Soc. 2012, 134, 9549-9552.

35. Goodman, C.K.; Wolfenden, M.L.; Nangia-Makker, P.; Michel, A.K.; Raz, A.; Cloninger, M.J. Multivalent scaffolds induce galectin-3 aggregation into nanoparticles. Beilstein J. Org. Chem. 2014, 10, 1570-1577.

36. Pavlov, G.M.; Errington, N.; Harding, S.E.; Korneeva, E.V.; Roy, R. Dilute solution properties of lactosylated polyamidoamine dendrimers and their structural characteristics. Polymer 2001, 42, 3671-3678.

37. Wang, X.; Ramstrom, O.; Yan, M. Dynamic light scattering as an efficient tool to study glyconanoparticle-lectin interactions. Analyst 2011, 136, 4174-4178.

38. Alvarez-Paino, M.; Bordege, V.; Cuervo-Rodriguez, R.; Munoz-Bonilla, A.; Fernandez-Garcia, M. Well-Defined Glycopolymers via RAFT Polymerization: Stabilization of Gold Nanoparticles. Macromol. Chem. Phys. 2014, 215, 1915-1924.

39. Yu, L.G.; Andrews, N.; Zhao, Q.; McKean, D.; Williams, J.F.; Connor, L.J.; Gerasimenko, O.V.; Hilkens, J.; Hirabayashi, J.; Kasai, K.; et al. Galectin-3 interaction with Thomsen-Friedenreich disaccharide on cancer-associated MUC1 causes increased cancer cell endothelial adhesion. J. Biol. Chem. 2007, 282, 773-781.

40. Dam, T.K.; Brewer, C.F. Thermodynamic studies of lectin-carbohydrate interactions by isothermal titration calorimetry. Chem. Rev. 2002, 102, 387-429.

41. Wang, X.; Matei, E.; Gronenborn, A.M.; Ramstrom, O.; Yan, M. Direct Measurement of Glyconanoparticles and Lectin Interactions by Isothermal Titration Calorimetry. Anal. Chem. 2012, 84, 4248-4252.

42. Adamova, L.; Malinovska, L.; Wimmerova, M. New Sensitive Detection Method for Lectin Hemagglutination using Microscopy. Microsc. Res. Tech. 2014, 77, 841-849.

43. Baek, M.G.; Roy, R. Synthesis and protein binding properties of T-antigen containing GlycoPAMAM dendrimers. Bioorg. Med. Chem. 2002, 10, 11-17.

44. Hu, D.; Fry, S.R.; Huang, J.X.; Ding, X.; Qiu, L.; Pan, Y.; Chen, Y.; Jin, J.; McElnea, C.; Buechler, J.; et al. Comparison of surface plasmon resonance, resonant waveguide grating 
biosensing and enzyme linked immunosorbent assay (ELISA) in the evaluation of a dengue virus immunoassay. Biosensors 2013, 3, 297-311.

45. Heinrich, L.; Tissot, N.; Hartmann, D.J.; Cohen, R. Comparison of the results obtained by ELISA and surface plasmon resonance for the determination of antibody affinity. J. Immunol. Methods 2010, 352, 13-22.

46. Fulop, L.; Mandity, I.M.; Juhasz, G.; Szegedi, V.; Hetenyi, A.; Weber, E.; Bozso, Z.; Simon, D.; Benko, R.; Kiraly, Z.; et al. A Foldamer-Dendrimer Conjugate Neutralizes Synaptotoxic $\beta$ Amyloid Oligomers. PLoS ONE 2012, 7, e39485.

47. Rhodes, D.C.J. Importance of carbohydrate in the interaction of Tamm-Horsfall protein with complement 1q and inhibition of classical complement activation. Immunol. Cell Biol. 2006, 84, 357-365.

48. Nakamura-Tsuruta, S.; Yasuda, M.; Nakamura, T.; Shinoda, E.; Furuyashiki, T.; Kakutani, R.; Takata, H.; Kato, Y.; Ashida, H. Comparative analysis of carbohydrate-binding specificities of two anti-glycogen monoclonal antibodies using ELISA and surface plasmon resonance. Carbohydr. Res. 2012, 350, 49-54.

49. Chiodo, F.; Marradi, M.; Tefsen, B.; Snippe, H.; van Die, I.; Penades, S. High Sensitive Detection of Carbohydrate Binding Proteins in an ELISA-Solid Phase Assay Based on Multivalent Glyconanoparticles. PLoS ONE 2013, 8, e73027.

50. Lundquist, J.J.; Debenham, S.D.; Toone, E.J. Multivalency effects in protein-carbohydrate interaction: The binding of the Shiga-like toxin 1 binding subunit to multivalent C-linked glycopeptides. J. Org. Chem. 2000, 65, 8245-8250.

51. Branson, T.R.; McAllister, T.E.; Garcia-Hartjes, J.; Fascione, M.A.; Ross, J.F.; Warriner, S.L.; Wennekes, T.; Zuilhof, H.; Turnbull, W.B. A Protein-Based Pentavalent Inhibitor of the Cholera Toxin B-Subunit. Angew. Chem. Int. Ed. 2014, 53, 8323-8327.

52. Wu, J.; Zhu, J.; Yin, H.; Buckanovich, R.J.; Lubman, D.M. Analysis of Glycan Variation on Glycoproteins from Serum by the Reverse Lectin-Based ELISA Assay. J. Proteome Res. 2014, 13, 2197-2204.

53. Page, D.; Zanini, D.; Roy, R. Macromolecular recognition: Effect of multivalency in the inhibition of binding of yeast mannan to concanavalin A and pea lectins by mannosylated dendrimers. Bioorg. Med. Chem. 1996, 4, 1949-1961.

54. Foxall, C.; Watson, S.R.; Dowbenko, D.; Fennie, C.; Lasky, L.A.; Kiso, M.; Hasegawa, A.; Asa, D.; Brandley, B.K. The 3 Members of the Selectin Receptor Family Recognize a Common Carbohydrate Epitope, the Sialyl Lewis Oligosaccharide. J. Cell Biol. 1992, 117, 895-902.

55. Nilsson, U.; Striker, R.T.; Hultgren, S.J.; Magnusson, G. PapG adhesin from E-coli J96 recognizes the same saccharide epitope when present on whole bacteria and as isolated protein. Bioorg. Med. Chem. 1996, 4, 1809-1817.

56. Andre, S.; Ortega, P.J.C.; Perez, M.A.; Roy, R.; Gabius, H.J. Lactose-containing starburst dendrimers: Influence of dendrimer generation and binding-site orientation of receptors (plant/animal lectins and immunoglobulins) on binding properties. Glycobiology 1999, 9, 1253-1261.

57. Barondes, S.H.; Castronovo, V.; Cooper, D.N.W.; Cummings, R.D.; Drickamer, K.; Feizi, T.; Gitt, M.A.; Hirabayashi, J.; Hughes, C.; Kasai, K.; et al. Galectins-A Family of Animal Beta-Galactoside-Binding Lectins. Cell 1994, 76, 597-598. 
58. Barondes, S.H.; Cooper, D.N.W.; Gitt, M.A.; Leffler, H. Galectins-Structure and Function of a Large Family of Animal Lectins. J. Biol. Chem. 1994, 269, 20807-20810.

59. Klyosov, A.A.; Witczak, Z.J.; Platt, D. Galectins; Wiley: Hoboken, NJ, USA, 2008.

60. Leffler, H.; Carlsson, S.; Hedlund, M.; Qian, Y.N.; Poirier, F. Introduction to galectins. Glycoconj. J. 2002, 19, 433-440.

61. Friedrichs, J.; Manninen, A.; Muller, D.J.; Helenius, J. Galectin-3 regulates integrin alpha2beta1mediated adhesion to collagen-I and -IV. J. Biol. Chem. 2008, 283, 32264-32272.

62. Stillman, B.N.; Hsu, D.K.; Pang, M.; Brewer, C.F.; Johnson, P.; Liu, F.T.; Baum, L.G. Galectin-3 and galectin-1 bind distinct cell surface glycoprotein receptors to induce T cell death. J. Immunol. 2006, 176, 778-789.

63. Delacour, D.; Greb, C.; Koch, A.; Salomonsson, E.; Leffler, H.; Le Bivic, A.; Jacob, R. Apical sorting by galectin-3-dependent glycoprotein clustering. Traffic 2007, 8, 379-388.

64. Zhao, Q.; Barclay, M.; Hilkens, J.; Guo, X.; Barrow, H.; Rhodes, J.M.; Yu, L.-G. Interaction between circulating galectin-3 and cancer-associated MUC1 enhances tumour cell homotypic aggregation and prevents anoikis. Mol. Cancer 2010, 9, 154, doi:10.1186/1476-4598-9-154.

65. Nieminen, J.; Kuno, A.; Hirabayashi, J.; Sato, S. Visualization of galectin-3 oligomerization on the surface of neutrophils and endothelial cells using fluorescence resonance energy transfer. J. Biol. Chem. 2007, 282, 1374-1383.

66. Funasaka, T.; Raz, A.; Nangia-Makker, P. Galectin-3 in angiogenesis and metastasis. Glycobiology 2014, 24, 886-891.

67. Pace, K.E.; Lee, C.; Stewart, P.L.; Baum, L.G. Restricted receptor segregation into membrane microdomains occurs on human $\mathrm{T}$ cells during apoptosis induced by galectin-1. J. Immunol. 1999, 163, 3801-3811.

68. Tinari, N.; Kuwabara, I.; Huflejt, M.E.; Shen, P.F.; Iacobelli, S.; Liu, F.T. Glycoprotein 90K/MAC2BP interacts with galectin-1 and mediates galectin-1-induced cell aggregation. Int. J. Cancer 2001, 91, 167-172.

69. Sacchettini, J.C.; Baum, L.G.; Brewer, C.F. Multivalent protein-carbohydrate interactions. A new paradigm for supermolecular assembly and signal transduction. Biochemistry 2001, 40, 3009-3015.

70. Thijssen, V.L.; Griffioen, A.W. Galectin-1 and-9 in angiogenesis: A sweet couple. Glycobiology 2014, 24, 915-920.

71. Astorgues-Xerri, L.; Riveiro, M.E.; Tijeras-Raballand, A.; Serova, M.; Neuzillet, C.; Albert, S.; Raymond, E.; Faivre, S. Unraveling galectin-1 as a novel therapeutic target for cancer. Cancer Treat. Rev. 2014, 40, 307-319.

72. Ahmad, N.; Gabius, H.J.; Kaltner, H.; Andre, S.; Kuwabara, I.; Liu, F.T.; Oscarson, S.; Norberg, T.; Brewer, C.F. Thermodynamic binding studies of cell surface carbohydrate epitopes to galectins-1, -3 and -7: Evidence for differential binding specificities. Can. J. Chem. 2002, 80, 1096-1104.

73. Cumpstey, I.; Salomonsson, E.; Sundin, A.; Leffler, H.; Nilsson, U.J. Studies of arginine-arene interactions through synthesis and evaluation of a series of galectin-binding aromatic lactose esters. ChemBioChem 2007, 8, 1389-1398.

74. Cumpstey, I.; Salomonsson, E.; Sundin, A.; Leffler, H.; Nilsson, U.J. Double affinity amplification of galectin-ligand interactions through arginine-arene interactions: Synthetic, 
thermodynamic, and computational studies with aromatic diamido thiodigalactosides. Chem. Eur. J. 2008, 14, 4233-4245.

75. Wolfenden, M.L.; Cloninger, M.J. Mannose/glucose-functionalized dendrimers to investigate the predictable tunability of multivalent interactions. J. Am. Chem. Soc. 2005, 127, 12168-12169.

76. Woller, E.K.; Walter, E.D.; Morgan, J.R.; Singel, D.J.; Cloninger, M.J. Altering the strength of lectin binding interactions and controlling the amount of lectin clustering using mannose/hydroxyl-functionalized dendrimers. J. Am. Chem. Soc. 2003, 125, 8820-8826.

77. Mansfield, M.L. Surface adsorption of model dendrimers. Polymer 1996, 37, 3835-3841.

78. Jackson, C.L.; Chanzy, H.D.; Booy, F.P.; Drake, B.J.; Tomalia, D.A.; Bauer, B.J.; Amis, E.J. Visualization of dendrimer molecules by transmission electron microscopy (TEM): Staining methods and Cryo-TEM of vitrified solutions. Macromolecules 1998, 31, 6259-6265.

79. Walter, E.D.; Sebby, K.B.; Usselman, R.J.; Singel, D.J.; Cloninger, M.J. Characterization of heterogeneously functionalized dendrimers by mass spectrometry and EPR spectroscopy. $J$. Phys. Chem. B 2005, 109, 21532-21538.

80. Dam, T.K.; Brewer, C.F. Effects of clustered epitopes in multivalent ligand-receptor interactions. Biochemistry 2008, 47, 8470-8476.

81. Burke, S.D.; Zhao, Q.; Schuster, M.C.; Kiessling, L.L. Synergistic formation of soluble lectin clusters by a templated multivalent saccharide ligand. J. Am. Chem. Soc. 2000, 122, 4518-4519.

82. Ahmad, N.; Gabius, H.J.; Andre, S.; Kaltner, H.; Sabesan, S.; Roy, R.; Liu, B.C.; Macaluso, F.; Brewer, C.F. Galectin-3 precipitates as a pentamer with synthetic multivalent carbohydrates and forms heterogeneous cross-linked complexes. J. Biol. Chem. 2004, 279, 10841-10847.

83. Kiessling, L.L.; Gestwicki, J.E.; Strong, L.E. Synthetic multivalent ligands in the exploration of cell-surface interactions. Curr. Opin. Chem. Biol. 2000, 4, 696-703.

84. Page, M.I.; Jencks, W.P. Entropic contributions to rate accelerations in enzymic and intramolecular reactions and chelate effect. Proc. Natl. Acad. Sci. USA 1971, 68, 1678-1683.

85. Weber, M.; Bujotzek, A.; Haag, R. Quantifying the rebinding effect in multivalent chemical ligand-receptor systems. J. Chem. Phys. 2012, 137, doi:10.1063/1.4739501.

86. Woller, E.D. Mannose Functionalized PAMAM Dendrimers: Their Synthesis, Characterization and Use in Refining the Model of Protein Carbohydrate Interactions, PhD Thesis, Montana State University, Bozeman, MT, USA, April 2003.

87. Seah, N.; Santacroce, P.V.; Basu, A. Probing the Lactose-GM3 Carbohydrate-Carbohydrate Interaction with Glycodendrimers. Org. Lett. 2009, 11, 559-562.

88. Smith, P.K.; Krohn, R.I.; Hermanson, G.T.; Mallia, A.K.; Gartner, F.H.; Provenzano, M.D.; Fujimoto, E.K.; Goeke, N.M.; Olson, B.J.; Klenk, D.C. Measurement of Protein Using Bicinchoninic Acid. Anal. Biochem. 1985, 150, 76-85.

Sample Availability: Samples of the compounds are available from the authors.

(C) 2015 by the authors; licensee MDPI, Basel, Switzerland. This article is an open access article distributed under the terms and conditions of the Creative Commons Attribution license (http://creativecommons.org/licenses/by/4.0/). 